\title{
Cape Canaveral Air Force Station Integrated Resource Assessment
}

\section{Volume 2: Baseline Detail}

December 1993

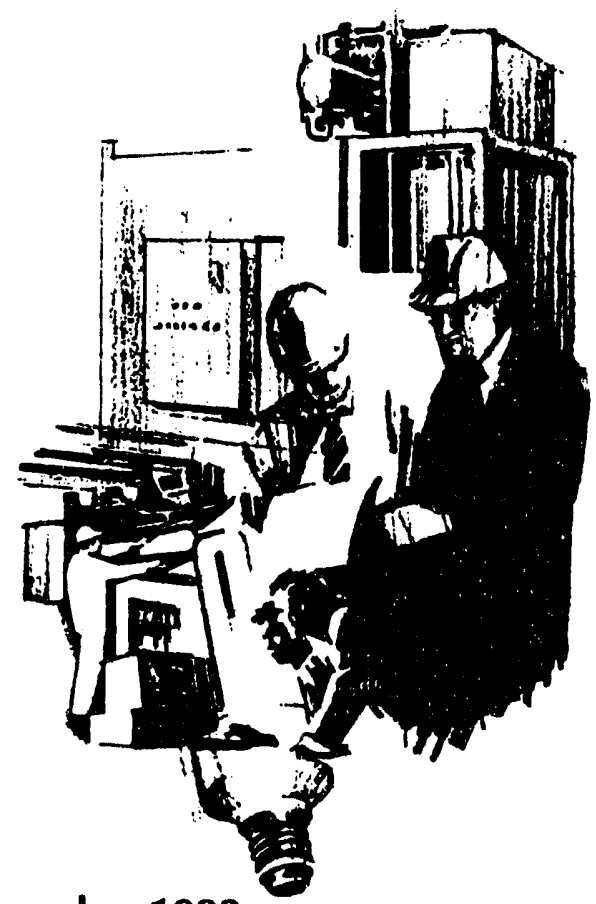

Prepared for the U.S. Department of Energy Federal Energy Management Program under Contract DE-AC06-76RLO 1830

Pacific Northwest Laboratory Operated for the U.S. Department of Energy by Battelle Memorial Institute

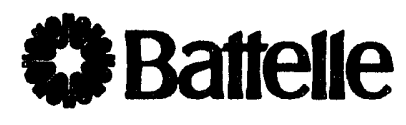




\title{
DISCLAIMER
}

This report was prepared as an account of work sponsored by an agency of the United States Government. Neither the United States Government nor any agency thereof, nor Battelle Memorial Institute, nor any of their employees, makes any warranty, expressed or implied, or assumes any legal liability or responsibility for the accuracy, completeness, or usefulness of any information, apparatus, product, or process disclosed, or represents that its use would not infringe privately owned rights. Reference herein to any specific commercial product, process, or service by trade name, trademark, manufacturer, or otherwise does not necessarily constitute or imply its endorsement, recommendation, or favoring by the United States Government or any agency thereof, or Battelle Memorial Institute. The views and opinions of authors expressed herein do not necessarily state or reflect those of the United States Government or any agency thereof.

\author{
PACIFIC NORTHWEST LABORATORY \\ operated by \\ BATTELLE MEMORIAL INSTITUTE \\ for the \\ UNITED STATES DEPARTMENT OF ENERGY \\ under Contract DE-AC06-76RLO 1830
}

Printed in the United States of America

Available to DOE and DOE contractors from the

Office of Scientific and Technical Information, P.O. Box 62, Oak Ridge, TN 37831; prices available from (615) 576-8401. FTS 626-8401.

Available to the public from the National Technical Information Service, U.S. Department of Commerce, 5285 Port Royal Rd., Springfield, VA 22161. 
PNL-8969 Vol. 2

UC -350

\section{CAPE CANAVERAL AIR FORCE STATION \\ INTEGRATED RESOURCE ASSESSMENT}

VOLUME 2: BASELINE DETAIL
R. R. Wahlstrom
K. L. McMordie
S. A. Parker
D. A. King
W. F. Sandusky (Project Manager)

December 1993

Prepared for

the U.S. Department of Energy

Federal Energy Management Program

under Contract DE-ACO6-76RLO 1830

Pacific Northwest Laboratory

Richland, Washington 99352 


\section{ABSTRACT}

The U.S. Air Force (USAF) has tasked the Pacific Northwest Laboratory $(P N L),{ }^{(a)}$ in support of the 11.S. Department of Energy (DOE) Federal Energy Management Program (FEMP), to assess energy use at Cape Canaveral Air Force Station (AFS). The information obtained from this assessment will be used in identifying energy resource opportunities to reduce overall energy consumption by the station.

The primary focus of this report is to assess the current baseline energy consumption at Cape Canaveral AFS. It is a companion report to Volume 1, the Executive Summary, and Volume 3, the Resource Assessment. This assessment requires that information be obtained and characterized for buildings, utilities, energy sources, energy uses, and load profiles to be used to improve the current energy system on the station. The characteristics of electricity, diesel fuel, No. 2 fuel oil, and motor vehicl: gasoline (MOGAS) are analyzed for on-base facilities. The assessment examines basic regional information used to determine energy-use intensity (EUI) values for Cape Canaveral AFS facilities by building, fuel type, and energy end use. It also provides a summary of electricity consumption from Florida Power \& Light Company (FPL) metered data for 1985-1991. Load profile information obtained from FPL data is presented for the North, South, and Titan Substations for the four seasons of the year, including weekdays and weekends.

(a) Pacific Northwest Laboratory is operated by Battelle Memorial Institute for the U.S. Department of Energy under Contract DE-AC06-76RLO 1830. 


\section{SUMMARY}

The U.S. Air Force (USAF) has tasked the Pacific Northwest Laboratory (PNL), in support of the U.S. Department of Energy (DOE) Federal Energy Management Program (FEMP), to assess energy use at Cape Canaveral Air Force Station (AFS). The information obtained from this assessment will be used in identifying energy resource opportunities to reduce overall energy consumption by the station.

The primary focus of this report is to assess the current baseline energy consumption by Cape Canaveral AFS. This assessment requires that information be obtained and characterized for buildings, utilities, energy sources, energy uses, and load profiles to be used to improve the characterization of energy use by the station.

The characteristics of electricity, diesel fuel, No. 2 fuel oil, and motor vehicle gasoline (MOGAS) are analyzed for on-site facilities. Electrical service is provided by Florida Power \& Light (FPL), and diesel fuel, fuel oil, and gasoline are supplied through a contract with Johnson Controls World Services.

The assessment examines basic regional information used to determine energy-use intensity (EUI) values for Cape Canaveral AFS facilities by building, fuel type, and energy end use. It also provides a summary of electricity consumption from FPL metered data for 1985-1991. Load profile information obtained from FPL data is presented for the North, South, and Titan Substations for the four seasons of the year, including weekdays and weekends, providing an insight into the peak shaving or reduction potential at the station.

Cape Canaveral AFS is a 15,804-acre space command (SPACECOM) containing industrial facilities, a "Skid Strip," facilities for unmanned space launches, and a port operations area. In FY92, the number of people affecting energy consumption through their use of Cape Canaveral AFS facilities included 439 active-duty military personnel, 379 civilian personnel, and 6,965 civilian contractors. There is no military family housing at Cape Canaveral AFS. 
A total of 766 buildings with $4,411,172 \mathrm{ft}^{2}$ of floorspace were identified at Cape Canaveral AFS. Utilities include electricity, water, and sewage.

Table S.l shows a summation of the typical annual energy consumption and cost for all facilities at Cape Canaveral AFS. For each energy type, the annual total is shown in units appropriate to the energy type and in common units as a basis of comparison.

TABLE S.1. Typical Annual Energy Consumption and Costs at Cape Canaveral AFS

\begin{tabular}{|c|c|c|c|c|}
\hline Energy Type & Annual Total & $\begin{array}{c}\text { Annual } \\
\text { Total } \mathrm{MBtu}^{\text {(a) }}\end{array}$ & $\begin{array}{l}\text { Percent of } \\
\text { Total } \\
\end{array}$ & $\begin{array}{l}\text { Energy Cost } \\
1991 \$ \times 10^{3} \\
\end{array}$ \\
\hline Electricity & $192,074 \mathrm{MWh}$ & $655,549^{(b)}$ & 61.5 & 9,876 \\
\hline No. 2 Fuel $0 i 1$ & $924 \mathrm{kgal}$ & $128,265^{(c)}$ & 12.0 & 952 \\
\hline Diesel Fuel & $1,558 \mathrm{kgal}$ & $218,162^{(d)}$ & 20.5 & 1,558 \\
\hline MOGAS & $502 \mathrm{kgal}$ & 63,805 & 6.0 & 619 \\
\hline TOTALS: & & $1,065,781$ & 100.00 & 13,005 \\
\hline
\end{tabular}
(a) $1 \mathrm{MBtu}=1,000,000 \mathrm{Btu}$
(b) $3,413 \mathrm{Btu} / \mathrm{kWh}$
(c) $100,000 \mathrm{Btu} /$ therm; $1,050 \mathrm{Btu} / \mathrm{ft}^{3}$
(d) $0.1388 \mathrm{MBtu} / \mathrm{gal}$

Table S.2 breaks down electric energy use for the facilities at Cape Canaveral AFS. 
IABLE S.2. Cape Canaveral AFS Electrical Energy-Use Breakdown

\begin{tabular}{|c|c|c|c|c|c|c|c|c|c|c|c|c|}
\hline $\begin{array}{c}\text { site } \\
\text { iddg-xype }\end{array}$ & $\begin{array}{c}\text { Total } \\
\text { Duildinge } \\
\end{array}$ & $\begin{array}{c}\text { site Total } \\
\text { (eq fte) }\end{array}$ & $\begin{array}{c}\text { Overe11 } \\
\text { EuI }\end{array}$ & $\begin{array}{c}\text { rotal } \\
\text { (manb/yx) }\end{array}$ & $\begin{array}{c}\text { sieotrio } \\
\text { Hoat }\end{array}$ & $\begin{array}{l}\text { s1eotxio } \\
\text { cool }\end{array}$ & $\begin{array}{c}\text { zleotrio } \\
\text { veptiletion }\end{array}$ & $\begin{array}{c}\text { Elootrio } \\
\text { Dan }\end{array}$ & $\begin{array}{c}\text { rleotrio } \\
\text { cook }\end{array}$ & $\begin{array}{l}\text { Eleotrio } \\
\text { Light }\end{array}$ & $\begin{array}{c}\text { Eleotrio } \\
\text { Refrigeration }\end{array}$ & $\begin{array}{c}\text { Eloctrio } \\
\text { other }\end{array}$ \\
\hline ADMTE & 32 & 316,888 & 10.66 & 3,370 & 209,146 & $1,112,277$ & 221,022 & 120,117 & 256,679 & 964,326 & 34,058 & 478,501 \\
\hline BRR/ADM & 1 & 1,854 & 22.12 & & 6,211 & 10,790 & 2,132 & 1,391 & 1,261 & 9,505 & $\begin{array}{r}1,391 \\
250,750\end{array}$ & 8,250 \\
\hline сомсаты & 34 & 219,783 & 46.66 & 10.255 & 439,566 & $2,646,107$ & $1,520,890$ & 238,463 & 32,967 & $2,681,353$ & 252,750 & $2,542,889$ \\
\hline DET-RR & 3 & 1,585 & 12.42 & & 1.530 & 2,401 & 1,609 & 650 & 79 & 4,557 & 7,180 & 1,664 \\
\hline rOELDS? & 2 & 2.399 & 96.66 & 112 & 6,798 & 28,084 & 16,601 & 1,511 & 360 & 29,260 & 3,759 & 27,736 \\
\hline HAMEAR & 1 & 40,519 & 12.42 & 503 & 39,101 & 61,386 & 41,127 & 16,015 & 2,026 & 116,492 & 183,551 & 12,543 \\
\hline LAS-RED & 1 & 12,064 & 25.15 & 303 & 14,477 & 106,043 & 23,766 & 6,032 & 12,780 & 75,762 & 21,461 & 53,082 \\
\hline MTRPOOLI & 7 & 68,337 & 12.42 & 848 & 65,945 & 103,531 & 69,362 & 28,360 & 3,417 & 196,469 & 309,567 & 71,754 \\
\hline $\operatorname{sen}$ & 3 & 13,585 & 16.66 & 634 & 27,170 & 163,563 & 94,008 & 0,559 & 2,030 & 165,737 & 15,623 & 157,178 \\
\hline MASLENB (a) & 87 & 732,416 & 46.66 & 34,173 & $1,464,832$ & $8,018,209$ & $5,060,319$ & 461,422 & 109,862 & $0,935,475$ & 82,278 & $\because, 476,053$ \\
\hline Masowa (b) & 230 & 745,470 & 16.66 & 34,704 & $1,490,940$ & $8,973,439$ & $5,158,652$ & 469,646 & 111,021 & $9,094,734$ & 857,290 & $0,625,088$ \\
\hline Otraien & 4 & 2,580 & 16.66 & 147 & 19,160 & 115,343 & 66,294 & 6,035 & 1,437 & 116,876 & 11,017 & 110,841 \\
\hline PLI-BLD & 24 & 34,950 & 22.42 & 134 & 33,727 & 52,949 & 35,474 & 14,504 & 1,748 & 100,481 & 158,324 & 36,698 \\
\hline PLI-EOOU & 31 & 62,571 & 46.66 & 3,200 & 137,142 & 825,593 & 474,511 & 43,200 & 10,286 & 036,366 & 78,057 & 793,366 \\
\hline & 66 & $1,236,903$ & 16.66 & 37,716 & $2,473,806$ & $14,892,312$ & $8,359,369$ & 779,249 & 185,535 & $15,090,217$ & $1,422,430$ & $14,310,968$ \\
\hline nestrayt & 1 & 16,443 & 42.45 & 69 & 13,648 & 229,709 & 65,443 & 58,373 & 12,332 & 95,063 & 158,346 & 64,292 \\
\hline EEcURTY & 29 & 37,542 & 45.66 & 1,752 & 75,084 & 432,006 & 259,791 & 23,651 & 5,631 & 458,012 & 43,173 & 434,361 \\
\hline 8BOP & 27 & 219,099 & 12.42 & 2,720 & 211,431 & 331,935 & 222,385 & 90,926 & 10,953 & 629,910 & 992,510 & 230,054 \\
\hline SHOP-ELC & 7 & 77,132 & 12.42 & 958 & 74,432 & 116,855 & 78,289 & 32,010 & 3,857 & 221,755 & 369,408 & 00,989 \\
\hline SBOP-WPN & 1 & 5,150 & 12.42 & 6 & 4,970 & 7,802 & 5,227 & 2,137 & 258 & 18,806 & 23,330 & 5,408 \\
\hline 650R-6ra & 100 & 135,553 & 12.42 & 1,931 & 130,209 & 235,663 & 157,006 & 64,554 & 7.778 & 467,215 & 704,655 & 263,331 \\
\hline TRATwe & 2 & 5,548 & 8.38 & 16 & 1.442 & 16,509 & 3,828 & 2,164 & 1,412 & 24,591 & 2,497 & 3,939 \\
\hline was & 73 & 389,801 & 12.42 & 1.039 & 376,158 & 390,569 & 395,510 & 261,767 & 29,490 & $1,120,678$ & $1,765,799$ & 409,291 \\
\hline \multirow{2}{*}{\multicolumn{4}{|c|}{$\begin{array}{l}\text { Puime (Eet.) } \\
\text { Ext. Light. (Eot.) } \\
\text { Line Loes (Eat.) }\end{array}$}} & $\begin{array}{l}1,658 \\
1,750\end{array}$ & & & & & & & & \\
\hline & & & & 20,012 & & & & & & & & \\
\hline Toteles & 766 & 412,172 & & 192,074 & $\operatorname{tal}$ & 10 & tion. & & & & & \\
\hline
\end{tabular}

(a) wask loaed bulldinge

(b) wask ovned buildinge 


\section{CONTENTS}

ABSTRACT . . . . . . . . . . . . . . . . . . . . .

SUMMARY . . . . . . . . . . . . . . . . . . . . v v

ABBREVIATIONS AND ACRONYMS . . . . . . . . . . . . . . . . XV

1.0 PHYSICAL CHARACTERISTICS ................... 1.1

1.1 SITE PROFILE . . . . . . . . . . . . . . . . 1.1

1.1 .1 History .................... . . 1.1

1.1 .2 Mission .................. . . 1.2

1.1.3 Population ................. 1.3

1.1.4 Existing Land Use . . . . . . . . . . . . . 1.3

1.2 BUILDING AND FACILITY PROFILE . . . . . . . . . . . . 1.3

1.2.1 Building Characterization . . . . . . . . . 1.3

1.2.2 Utility Characterization ............ 1.13

1.2.3 Water Distribution Characterization . . . . . . 1.13

1.2.4 Sewage Treatment Characterization ......... 1.13

1.2.5 Exterior Lighting Characterization . . . . . . . 1.13

2.0 ENERGY SOURCE CHARACTERISTICS . . . . . . . . . . . . . . 2.1

2.1 ELECTRIC SUPPLY SOURCE DESCRIPTION . . . . . . . . . . 2.1

2.2 DIESEL/FUEL OIL SUPPLY SOURCE DESCRIPTION $\ldots$. . . . . . 2.2

2.3 VEHICLE GASOLINE/DIESEL SUPPLY SOURCE DESCRIPTION $\ldots$. . . 2.3

2.4 NATURAL-GAS SUPPLY SOURCE DESCRIPTION $\ldots \ldots$. . . . . . . 2.4

3.0 ENERGY-USE INTENSITIES . . . . . . . . . . . . . . . . 3.1

3.1 REGIONAL ENERGY-USE DATA SOURCES . . . . . . . . . . 3.1

3.2 SITE-SPECIFIC ENERGY-USE VALUES . . . . . . . . . . 3.2

4.0 ELECTRICAL CONSUMPTION . . . . . . . . . . . . . . . 4.1 
4.1 METERING AND DATA SUMMARY . . . . . . . . . . . . 4.1

4.2 ENERGY-USE BREAKDOWN ................... 4.2

4.3 LOAD PROFILE . . . . . . . . . . . . . . . . 4.2

5.0 NATURAL-GAS CONSUMPTION . . . . . . . . . . . . . . . . 5.1

5.1 METERING AND DATA SUMMARY . . . . . . . . . . . . . 5.1

6.0 DIESEL FUEL CONSUMPTION . . . . . . . . . . . . . . . . 6.1

6.1 METERING AND DATA SUMMARY . . . . . . . . . . . . . 6.1

6.2 ENERGY-USE BREAKDOWN ................... 6.1

7.0 REFERENCES ........................... . . . 7.1

8.0 BIBLIOGRAPHY . . . . . . . . . . . . . . . . . . . . . . 8.1

APPENDIX - REGIONAL ENERGY-USE INTENSITY VALUES . . . . . . . . . . . A.l 


\section{FIGURES}

4.1 Cape Canaveral AFS Electrical Consumption, January 1985

to December 1991 .................... 4.15

4.2 Cape Canaveral AFS End User Electrical Consumption, 1991 . . . 4.15

4.3 Load Profile at Cape Canaveral AFS - Spring Weekday (1991) . . 4.16

4.4 Load Profile at Cape Canaveral AFS - Spring Weekend (1991) . . 4 4.16

4.5 Load Profile at Cape Canaveral AFS - Summer Weekday (1991) • • 4.17

4.6 Load Profile at Cape Canaveral AFS - Summer Weekend (1991) . . 4.17

4.7 Load Profile at Cape Canaveral AFS - Fall Weekday (1991) . . . 4.18

4.8 Load Profile at Cape Canaveral AFS - Fall Weekend (1991) . . . 4.18

4.9 Load Profile at Cape Canaveral AFS - Winter Weekday (1991) . . 4.19

4.10 Load Profile at Cape Canaveral AFS - Winter Weekend (1991) • . 4.19

\section{TABLES}

S.1 Typical Annual Energy Consumption and Costs at Cape Canaveral AFS ..................... . . vi

S.2 Cape Canaveral AFS Electrical Energy-Use Breakdown . . . . . . vii

1.1 Land-Use Information at Cape Canaveral AFS . . . . . . . . . 1.4

1.2 Building Characterization at Cape Canaveral AFS . . . . . . . 1.5

1.3 Installed Lighting at Cape Canaveral AFS . . . . . . . . . 1.6

1.4 Interior Lighting Fixtures and Corresponding Energy
Consumption at Cape Canaveral AFS . . . . . . . . . . . . 1.8

1.5 Cape Canaveral AFS Boilers . . . . . . . . . . . . . 1.11

1.6 Cape Canaveral AFS Air-Conditioning/Refrigeration Equipment . . 1.14

1.7 Transformers at Cape Canaveral AFS . . . . . . . . . . . 1.16

1.8 Exterior Lighting Fixtures and Corresponding Energy
Consumption at Cape Canaveral AFS . . . . . . . . . . . 1.17 
2.1 Typical Annual Energy Consumption and Energy Costs at Cape

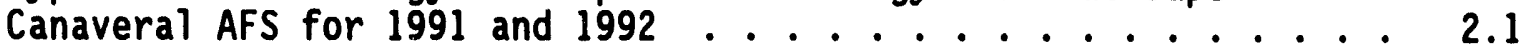

2.2 Cape Canaveral AFS Electric Rate Structure Breakdown - 1991 . . 2.2

2.3 Cape Canaveral AFS Mobile Electric Power Generators . . . . . 2.3

2.4 Vehicles Used at Cape Canaveral AFS . . . . . . . . . . . 2.4

3.1 Cape Canaveral AFS Reimbursable Electricity Consumption

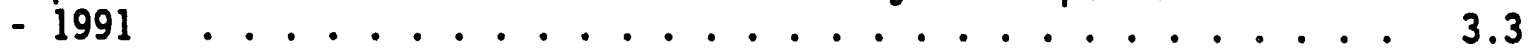

3.2 Cape Canaveral AFS EUI Information ............ 3.5

4.1 Florida Power \& Light Electric Meter Readings

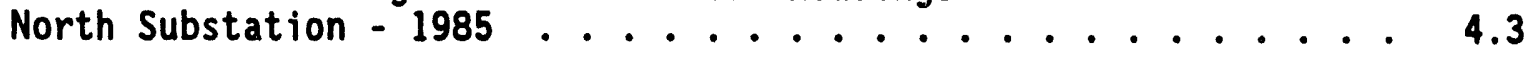

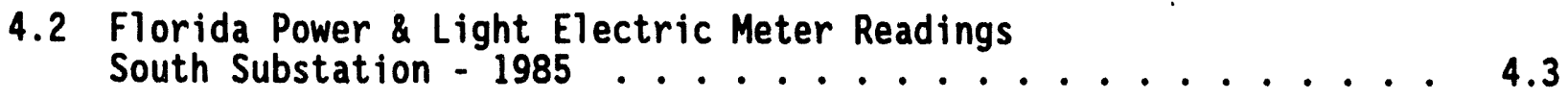

4.3 Florida Power \& Light Electric Meter Readings Titan Substation - $1985 \ldots \ldots . \ldots . . \ldots 4$

4.4 Florida Power \& Light Electric Meter Readings

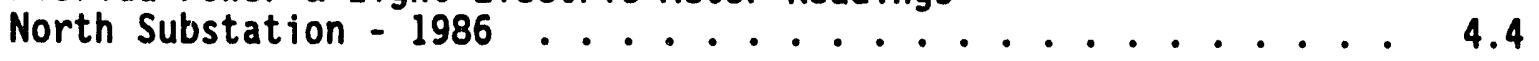

4.5 Florida Power \& Light Electric Meter Readings
South Substation - . . . . . . . . . . . 4986.5

4.6 Florida Power \& Light Electric Meter Readings Titan Substation - $1986 \ldots \ldots . \ldots . . \ldots 4 . \ldots$

4.7 Florida Power \& Light Electric Meter Readings North Substation - 1987 . . . . . . . . . . . 4.6

4.8 Florida Power \& Light Electric Meter Readings South Substation - 1987 ............... . 4.6

4.9 Florida Power \& Light Electric Meter Readings Titan Substation - 1987 ............... 4.7

4.10 Florida Power \& Light Electric Meter Readings North Substation - 1988

4.11 Florida Power \& Light Electric Meter Readings South Substation - $1988 \ldots \ldots$. . . . . . . . .

4.12 Florida Power \& Light Electric Meter Readings Titan Substation - 1988 
4.13 Florida Power \& Light Electric Meter Readings North Substation - 1989

4.14 Florida Power \& Light Electric Meter Readings

4.15 Florida Power \& Light Electric Meter Readings Titan Substation - 1989

4.16 Florida Power \& Light Electric Meter Readings North Substation - 1990

4.17 Florida Power \& Light Electric Meter Readings South Substation - 1990

4.18 Florida Power \& Light Electric Meter Readings Titan Substation - 1990

4.19 Florida Power \& Light Electric Meter Readings North Substation - 1991

4.20 Florida Power \& Light Electric Meter Readings South Substation - 1991

4.21 Florida Power \& Light Electric Meter Readings

4.22 Cape Canaveral AFS Electric Energy-Use Breakdown

6.1 Fossil Fuel Use for Cape Canaveral AFS - October 1991 through September 1992

A.1 Office Electricity Baseline Development Notes EUI Development

A.2 Restaurant Electricity Baseline Development Notes EUI Development

A.3 Retail Electricity Baseline Development Notes EUI Development

A.4 Grocery Electric Baseline Development Notes EUI Development

A.5 Warehouse Electricity Baseline Development Notes EUI Development

A.6 School Electricity Baseline Development Notes EUI Development 
A.7 Health Electricity Baseline Development Notes EUI Development

A.8 Lodging Electricity Baseline Development Notes EUI Development

A.9 Miscellaneous Buildings Electricity Baseline Development Notes EUI Development .................... A.6

A.10 Church/Assembly Building Electricity Baseline Development Notes EUI Development

A.11 Office Fossil Fuel Baseline Development Notes EUI Development

A.12 Restaurant Fossil Fuel Baseline Development Notes EUI Development

A.13 Retail Fossil Fuel Basel ine Development Notes EUI Development

A.14 Grocery Fossil Fuel Baseline Development Notes EUI Development

A.15 Warehouse Fossil Fuel Baseline Development Notes EUI Development

A.16 School Fossil Fuel Baseline Development Notes EUI Development

A.17 Health Fossil Fuel Baseline Development Notes EUI Development

A.18 Lodging Fossil Fuel Baseline Development Notes EUI Development

A.19 Miscellaneous Buildings Fossil Fuel Baseline Development Notes EUI Development 


\section{ABBREVIATIONS AND ACRONYMS}

\begin{tabular}{|c|c|}
\hline $\begin{array}{l}\text { AFB } \\
\text { AFS } \\
\text { ASTG } \\
\text { Btu } \\
\text { CG } \\
\text { CLS } \\
\text { CRIT } \\
\text { CY } \\
\text { D } \\
\text { DEIS } \\
\text { DHW } \\
\text { DOE } \\
\text { EPA } \\
\text { EUI } \\
\text { FEMP } \\
\text { FPL } \\
\text { FSEC } \\
\text { FY } \\
\text { G } \\
\text { GD } \\
\text { GSLDT-3 } \\
\text { HPS } \\
\text { HVAC } \\
\text { HW } \\
\text { HW-E } \\
\text { IES } \\
\text { InC } \\
\text { KBtU } \\
\text { KSC } \\
\text { KVA } \\
\text { kW } \\
\text { KWh } \\
\text { LPS } \\
\text { MBtu } \\
\text { MEP } \\
\text { MH } \\
\text { MOGAS } \\
\text { MV } \\
\text { MWh } \\
\text { N/C } \\
\text { NASA } \\
\text { NLS } \\
\text { NOTU } \\
\text { PNL } \\
\text { SERC } \\
\text { SPACECOM } \\
\text { ST } \\
\text { TITN } \\
\end{array}$ & $\begin{array}{l}\text { Air Force Base } \\
\text { Air Force Station } \\
\text { Air Support Testing Group } \\
\text { British thermal unit } \\
\text { U.S. Coast Guard } \\
\text { commercial launch system } \\
\text { critical } \\
\text { calendar year } \\
\text { diesel } \\
\text { Defense Energy Information System } \\
\text { domestic hot water } \\
\text { U.S. Department of Energy } \\
\text { U.S. Environmental Protection Agency } \\
\text { energy-use intensity } \\
\text { Federal Energy Management Program } \\
\text { Florida Power \& Light } \\
\text { Florida Solar Energy Center } \\
\text { fiscal year } \\
\text { gasoline } \\
\text { General Dynamics } \\
\text { General Service Large Demand Time-of-Use } \\
\text { high-pressure sodium } \\
\text { heating, ventilating, and air conditioning } \\
\text { hot water } \\
\text { hot water-electric } \\
\text { Illuminating Engineering Society of North America } \\
\text { incandescent } \\
\text { thousand British thermal units } \\
\text { Kennedy Space Center } \\
\text { kilovoltampere } \\
\text { kilowatt } \\
\text { kilowatt-hour } \\
\text { low-pressure sodium } \\
\text { million British thermal units } \\
\text { mobile electric power } \\
\text { metal halide } \\
\text { motor vehicle gasoline } \\
\text { mercury vapor } \\
\text { megawatt-hour } \\
\text { noncritical } \\
\text { National Aeronautics and Space Administration } \\
\text { national launch system } \\
\text { Naval Ordnance Test Unit } \\
\text { Pacific Northwest Laboratory } \\
\text { Southeastern Electric Reliability Council } \\
\text { space command } \\
\text { steam } \\
\text { commercial Titan }\end{array}$ \\
\hline
\end{tabular}


UEC unit energy consumption

USAF U.S. Air Force

$V \quad$ volt

W watt 


\subsection{PHYSICAL CHARACTERISTICS}

\subsection{SITE PROFILE}

Cape Canaveral Air Force Station (AFS) is located on 15,804 acres on a barrier island off the central east coast of Florida. The site is approximately 50 miles east of Orlando and approximately equal distance between Miami and Jacksonville, Florida. The site is bounded on the north by the Kennedy Space Center (KSC), on the west by the Banana River, on the south by Port Canaveral, and on the east by the Atlantic Ocean. The Kennedy Space Center is owned and operated by the National Aeronautics and Space Administration (NASA).

The nearest civilian community to Cape Canaveral AFS is the city of Cape Canaveral, which is located adjacent to the south side of Port Canaveral. South of Cape Canaveral is Cocoa Beach, Florida. The nearest community to the west of the site is Titusville, Florida, which is approximately 20 miles away.

The topography of Cape Canaveral AFS is flat and much of the site is covered with native vegetation. Cape Canaveral AFS is the home of several threatened and endangered wildlife species. The site also has been designated as a national seashore to protect the current habitat and nesting area of sea turtles.

\subsubsection{History}

Cape Canaveral AFS was selected as the site for a U.S. missile testing range in 1947. The first launch on July 24, 1950 signaled the beginning of the space age for the United States.

After that initial launch, a long series of experimental launch programs began, initially including the Matador, Snark, Bomarc, Hound Dog, and Mace cruise missile programs. In 1953, the emphasis of the launch programs shifted to ballistic missiles, such as the Jupiter, Thor, Navy Polaris, and Atlas programs. Other programs followed that included the Mercury, Gemini, and Apollo manned space flights. 
Since April 1981, Cape Canaveral AFS has provided lead support for NASA's Space Shuttle program, as well as lead range for the Strategic Defense Iniciative Organization's in-orbit testing. Space Shuttle program launches are actually made from sites on the KSC.

\subsubsection{Misston}

Cape Canaveral AFS is the launch facility of the 45th Space Wing of the U.S. Air Force (USAF) Space Command (SPACECOM) that also includes Patrick Air Force Base (AFB), Antigua Air Station, Ascension Auxiliary Airfield, and other Florida mainland stations that provide tracking services. The focus of this document is Cape Canaveral AFS. A companion document has been prepared for Patrick AFB (Wahlstrom et al. 1993).

The primary mission of Cape Canaveral AFS is to provide the launch site, facilities, hardware, and support required to assemble, process, checkout, test, and launch all types of space boosters, upper stages, satellites, and other payloads (EDAW undated). The site also provides the facilities, infrastructure, and ground support for launch base instrumental requirements that include radar, telemetry, optics, command and control, communications, and collection and real-time processing of data.

Cape Canaveral AFS provides logistical support to a variety of major organizations in support of their primary missions. Some of the organizations that are tenants at Cape Canaveral AFS are the U.S. Naval Ordnance Test Unit, NASA, U.S. Army, and various commercial organizations.

The Cape Canaveral AFS is currently being considered as the site for either a national launch system (NLS) (Bechtel National, Inc. 1992) or a commercial launch system (CLS) that will be constructed north of the industrial area complex. The difference between the two systems is that CLS will provide greater opportunities for unmanned launch activities. Another distinct advantage of either the NLS or CLS is all fabrication and prelaunch activities are conducted at ground level compared to the present system where prelaunch activities are conducted while the missile is in a vertical position. Initial estimates indicate that the cost of launches using the NLS or CLS will be reduced by a factor of 10 over the current typical cost. 
If either the NLS or CLS is constructed at Cape Canaveral AFS, a large additional electrical load of up to 100,000 kVA will be required. The possibility of construction of cogeneration facilities will also exist that can reduce the overall electrical load at the site.

A decision whether to construct the NLS or CLS has not been made. However, if a decision is made to construct either the NLS or CLS, energy resource requirements will need to be determined and ways to implement conservation or demand-site activities will need to be considered.

\subsubsection{Population}

Currently a total of 7,783 personnel are employed at Cape Canaveral AFS. The largest fraction of this total is civilian contractors $(6,965)$. The remainder is either military personnel (439) or civilian personnel employed inj the result of appropriated funds (379). There is no military family housing at Cape Canaveral AFS (EDAW undated).

\subsubsection{Existing Land Use}

Most support facilities at Cape Canaveral AFS are centrally located in what is known as the "industrial area." This area includes facilities for administration, launch and range support and control, community services, recreation, and other industrial land uses. Table 1.1 provides a listing of the existing and proposed land uses.

\subsection{BUILDING AND FACILITY PROFILE}

This section includes a characterization of the types of buildings found at Cape Canaveral AFS. The buildings, major energy sources, age, building count, and floorspace are discussed.

\subsubsection{Building Characterization}

A total of 23 primary building categories were identified at Cape Canaveral AFS. These categories were based on information contained in the real-property data base, which are separated by uniqueness in terms of operation or ownership, construction, age, and energy use. A mnemonic letter 
IABLE 1.1. Land-Use Information at Cape Canaveral AFS

\begin{tabular}{lrr}
\multicolumn{1}{c}{ Land Use } & $\begin{array}{c}\text { Existing } \\
\text { (acres) }\end{array}$ & $\begin{array}{r}\text { Future } \\
\text { (acres) }\end{array}$ \\
\cline { 1 - 1 } Airfield & 1,129 & 1,120 \\
Runway/Taxiway/Apron & 105 & 105 \\
Industrial & 522 & 753 \\
Administrative & - & 266 \\
Outdoor Recreation & - & 410 \\
Open Space & 193 & 1,446 \\
Water & 1,768 & 1,768 \\
Launch Operations & 4,912 & 3,292 \\
Launch and Range Support & 7,075 & 5,366 \\
Launch and Range Control & - & 288 \\
Port Operations & 100 & 981 \\
Total & 15,804 & 15,794
\end{tabular}

code identifies each building type. A building categorization is provided in Table 1.2, along with information on floorspace, average age, average year built, and the number of buildings for each category.

The facility category entitled "Other" was identified from the realproperty list and includes items such as utility vaults, waste treatment buildings, and other unique facilities that have very low energy use. Real property items, such as fire protection and sprinkler systems, fire and security alarm systems, and outdoor facilities with no energy consumption, were not included in Table 1.2.

\section{Interior Lighting}

The existing energy consumption corresponding to the interior lighting at Cape Canaveral AFB was calculated using a formula that estimates the total number of fixtures for each building type at the station. The total number of fixtures was calculated by taking the footcandles required for a particular building type, multiplying by the total floor area of the building type, and 
IABLE 1.2. Building Characterization at Cape Canaveral AFS

\begin{tabular}{|c|c|c|c|c|c|c|}
\hline $\begin{array}{c}\text { Building } \\
\text { Type } \\
\end{array}$ & Description & $\begin{array}{l}\text { Total } \\
\text { Area } \\
\left(\mathrm{ft}^{2}\right) \\
\end{array}$ & $\begin{array}{c}\text { Average } \\
\text { Area } \\
\left(\mathrm{ft}^{2}\right) \\
\end{array}$ & $\begin{array}{c}\text { Average } \\
\text { Age }\end{array}$ & $\begin{array}{l}\text { Number of } \\
\text { Buildings }\end{array}$ & $\begin{array}{c}\text { Percentage } \\
\text { of } \\
\text { Buildings }\end{array}$ \\
\hline ADMIN & Adm Bldg & 316,888 & 9,903 & 30 & 32 & 4.18 \\
\hline BRK/ADM & Barracks, Admin & 1,854 & 1,854 & 32 & 1 & 0.13 \\
\hline COMCATN & Commun Fac & 219,783 & 6,464 & 25 & 34 & 4.44 \\
\hline DET-RR & Detached Rstrm & 1,585 & 528 & 25 & 3 & 0.39 \\
\hline FUELDSP & Fuel Bidg & 2,399 & 1,200 & 20 & 2 & 0.26 \\
\hline HANGAR & Hangar & 40,519 & 40,519 & 39 & 1 & 0.13 \\
\hline LAB-MED & Med Lab & 12,064 & 12,064 & 35 & 1 & 0.13 \\
\hline MTRPOOL & Maint Shop & 68,337 & 9,762 & 30 & 7 & 0.91 \\
\hline MWR & Morale, Rec & 13,585 & 4,528 & 22 & 3 & 0.39 \\
\hline NASLEAS & NASA-Leased & 732,416 & 8,419 & 27 & 87 & 11.36 \\
\hline NASOWN & NASA-Owned & 745,470 & 3,241 & 34 & 230 & 30.03 \\
\hline OTHER & Other & 9,580 & 2,395 & 22 & 4 & 0.52 \\
\hline PLT-BLD & Heat/Cool/Plant & 34,950 & 1,456 & 28 & 24 & 3.14 \\
\hline PLT-EQU & Maint Shop-Equip & 68,571 & 2,212 & 28 & 31 & 4.05 \\
\hline R\&D & Research \& Dev & $1,236,903$ & 18,741 & 31 & 66 & 8.62 \\
\hline RESTRNT & Restaurant & 16,443 & 16,443 & 34 & 1 & 0.13 \\
\hline SECURTY & Security Fac & 37,542 & 1,295 & 21 & 29 & 3.79 \\
\hline SHOP & Misc Maint Shop & 219,099 & 8,115 & 27 & 27 & 3.52 \\
\hline SHOP-ELC & Maint Shops-Elec & 77,132 & 11,019 & 31 & 7 & 0.91 \\
\hline SHOP-WPN & Maint Shops-Weapons & 5,150 & 5,150 & 36 & 1 & 0.13 \\
\hline STOR-UH & Unheated Storage & 155,553 & 1,556 & 26 & 100 & 13.05 \\
\hline TRAING & Training Fac & 5,548 & 2,774 & 32 & 2 & 0.26 \\
\hline WHS & Warehouse & 389,801 & 5,340 & 27 & 73 & 9.53 \\
\hline Total & & $4,411,172$ & & & 766 & 100.00 \\
\hline
\end{tabular}

dividing by the lumen output of the fixtures. The following assumptions were made to estimate the lighting energy consumption at Cape Canaveral AFS:

- The required footcandles were obtained from the Illuminating Engineering Society of North America (IES) Applications Handbook (IES 1981) or light-metered data gathered at the site.

- Installed lighting (footcandles) meets, but does not exceed, IES standards (IES 1981). Representative data obtained during site visits are listed in Table 1.3. 
TABLE 1.3. Installed Lighting at Cape Canaveral AFS

\begin{tabular}{|c|c|c|c|}
\hline $\begin{array}{l}\text { Facility } \\
\text { Number }\end{array}$ & Facility Name & $\begin{array}{l}\text { Light Reading } \\
\text { (footcandles) }\end{array}$ & $\begin{array}{l}\text { Light } \\
\text { Location }\end{array}$ \\
\hline 1744 & $\begin{array}{l}\text { Vehicle Maintenance } \\
\text { Shop - Hangar U }\end{array}$ & $\begin{array}{r}350 \\
80\end{array}$ & $\begin{array}{l}\text { hangar } \\
\text { offices }\end{array}$ \\
\hline 1604 & $\begin{array}{l}\text { Hangar H Space } \\
\text { Research Test }\end{array}$ & 110 & offices \\
\hline 54915 & $\begin{array}{l}\text { Engineering } \\
\text { Building }\end{array}$ & $\begin{array}{r}75 \\
11-35\end{array}$ & $\begin{array}{l}\text { offices } \\
\text { halls }\end{array}$ \\
\hline 1731 & Hangar M & $\begin{array}{l}75 \\
15\end{array}$ & $\begin{array}{l}\text { offices } \\
\text { halls }\end{array}$ \\
\hline 60680 & AE Support & 100 & $\begin{array}{l}\text { offices with newly } \\
\text { painted walls }\end{array}$ \\
\hline 1645 & Control Center & $100-120$ & $\begin{array}{l}\text { offices and selected } \\
\text { work areas }\end{array}$ \\
\hline 1704 & E\&L Building & $\begin{array}{r}90 \\
50-90\end{array}$ & $\begin{array}{l}\text { office } \\
\text { lobby }\end{array}$ \\
\hline
\end{tabular}

- Light output from each fixture is the mean lumen from the Lighting Technology Systems Matrix (FEMP 1993).

- Operating hours for each building type were assumptions based on observations and discussions with Cape Canaveral AFS staff.

- Utilization factors depict the fraction of lights in operation during occupied and unoccupied hours of the day. For example, a value of 1.0 indicates that all lights are operating, while a value of 0.5 indicates that half of the lights are operating. The percentages for each type of fixture (incandescent, fluorescent, and high-pressure sodium) for each building type were based on detailed audit data collected at other federal sites (Dixon et al. 1992).

- All incandescent lamps were assumed to be $60 \mathrm{~W}$ based on spot checks performed during site visits.

- High-pressure sodium fixtures were assumed to be $150 \mathrm{~W}$ based on information in the draft lighting management plans.

- The fluorescent fixture type was obtained by site visits of several building types and then applied to the remaining areas.

- To estimate the energy consumption of exit signs at the station, the buildings were assumed to have two doors and three exit signs per door. 
Table 1.4 shows the total number of fixtures for each building type and their corresponding energy consumption categorized by on- and off-peak hours, for occupied and unoccupied periods of the day, respectively.

\section{Boilers}

A total of 82 boilers are used at Cape Canaveral AFS. The USAF is responsible for the largest number of boilers (61) with a combined capacity of $37,117 \mathrm{kBtu} / \mathrm{h}$. The U.S. Navy has responsibility for 6 boilers with a combined capacity of $3,230 \mathrm{kBtu} / \mathrm{h}$. NASA is responsible for 15 of the boilers with a combined capacity of $11,384 \mathrm{kBtu} / \mathrm{h}$. Table 1.5 lists all the boilers, including the facility number, facility name, the output (in thousands of British thermal units per hour), the type of boiler, the agency involved, and the operational status of the facility in which they are installed.

\section{Air Conditioning and Refrigeration}

A wide range of air-conditioning, refrigeration, and chiller units (1,074 total) exists at Cape Canaveral AFS. The equipment ranges from 1-ton to 520-ton units for a total of 16,336 tons. The units have been categorized in correspondence with the area of the station in which they are located.

This information was gathered from the station's master heating, ventilating, and air-conditioning (HVAC) equipment list. The following assumptions were made to determine the baseline energy consumption of the equipment:

- The operating hours for the equipment assumes that half the tonnage is operated at equivalent rated full-load hours during the normal cooling season (PRAD Group 1992).

- Operating hours total 2,700 h/yr (PRAD Group 1992).

- On-peak hours are $30 \%$ and off-peak hours are $70 \%$ of the total operating hours.

- The efficiency of the existing equipment is $0.9 \mathrm{~kW} /$ ton (PRAD Group 1992). 
IABLE 1.4. Interior Lighting Fixtures and Corresponding Energy Consumption at Cape Canaveral AFS

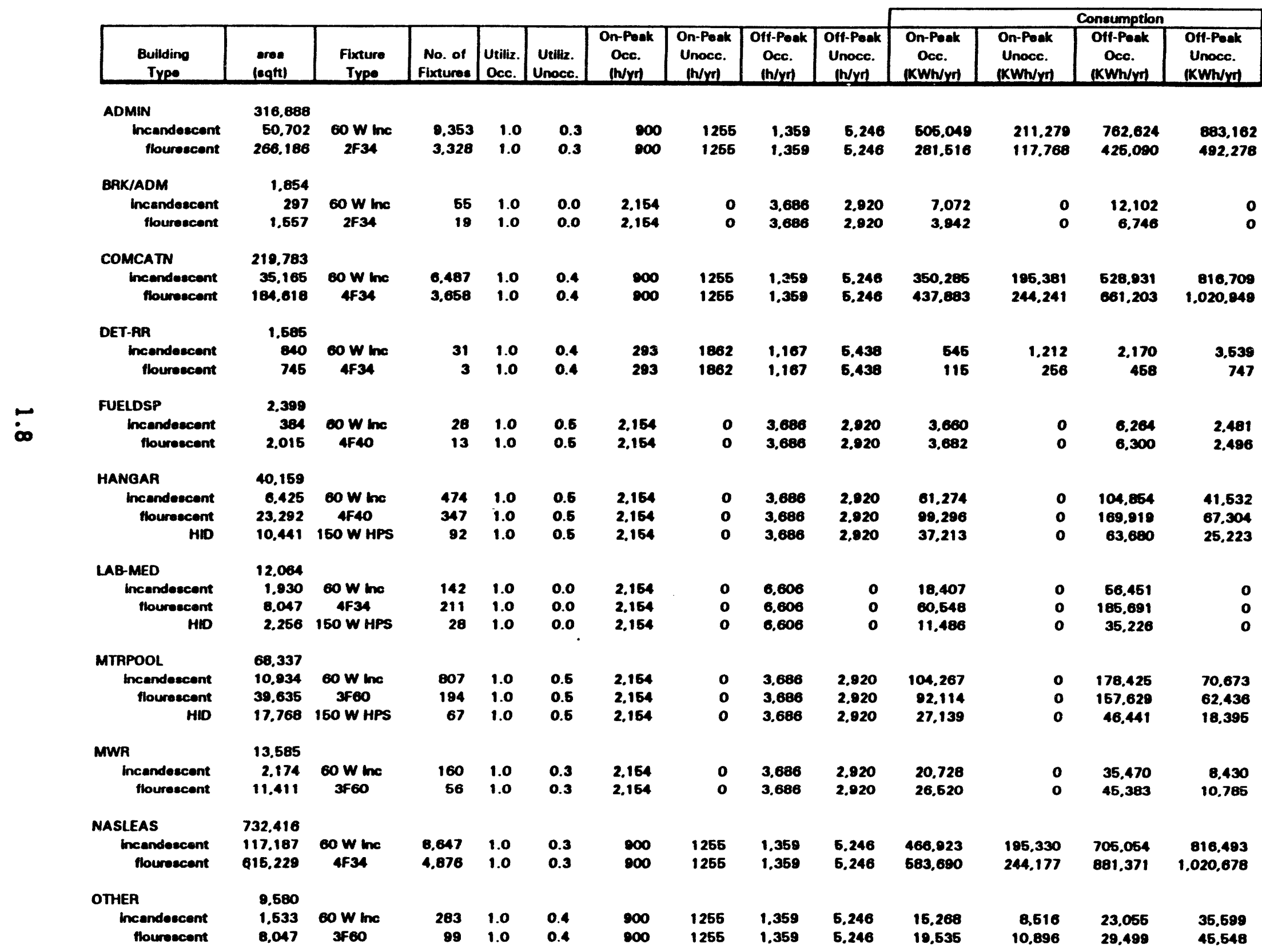


TABLE 1.4. (contd)

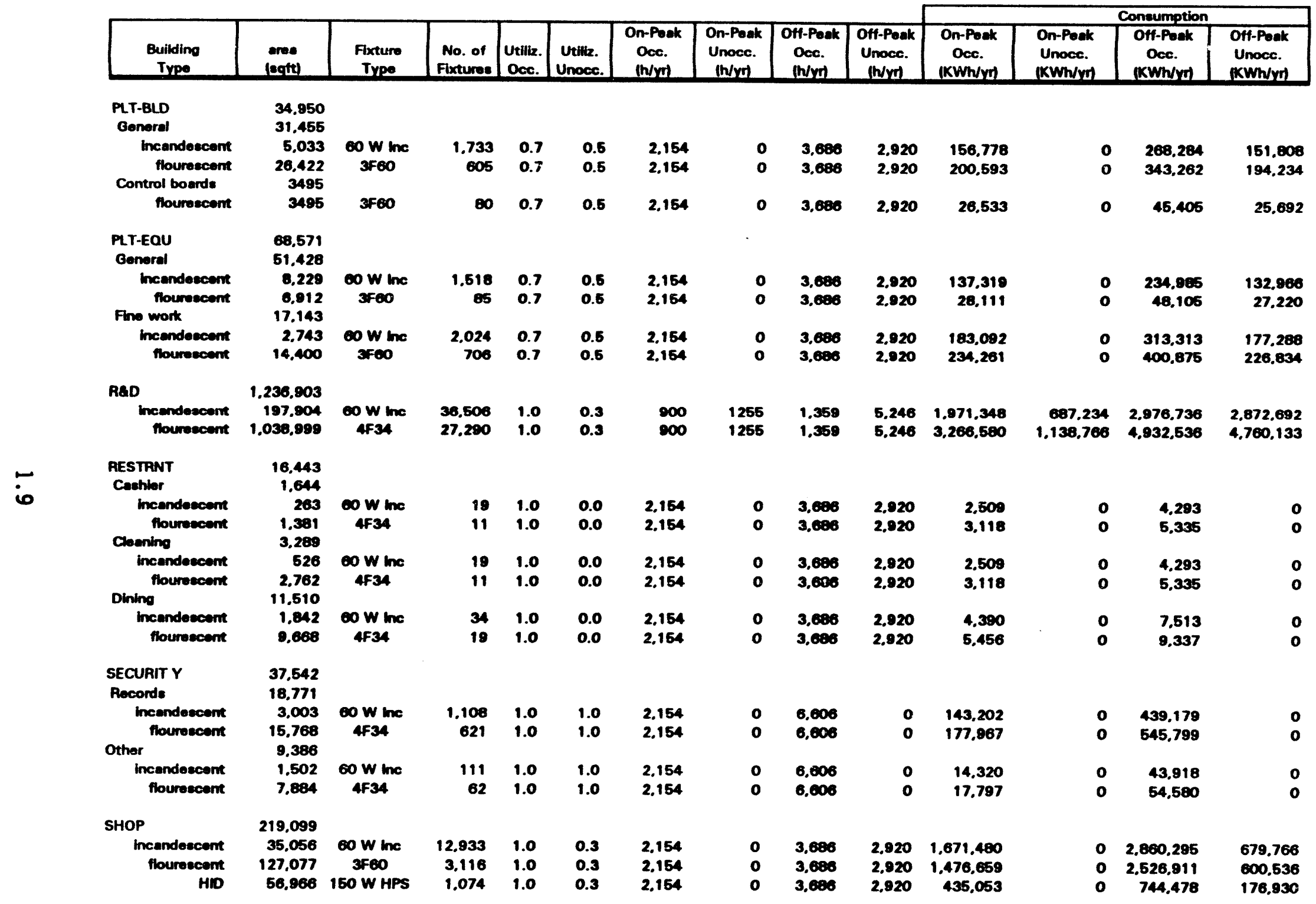


TABLE 1.4. (contd)

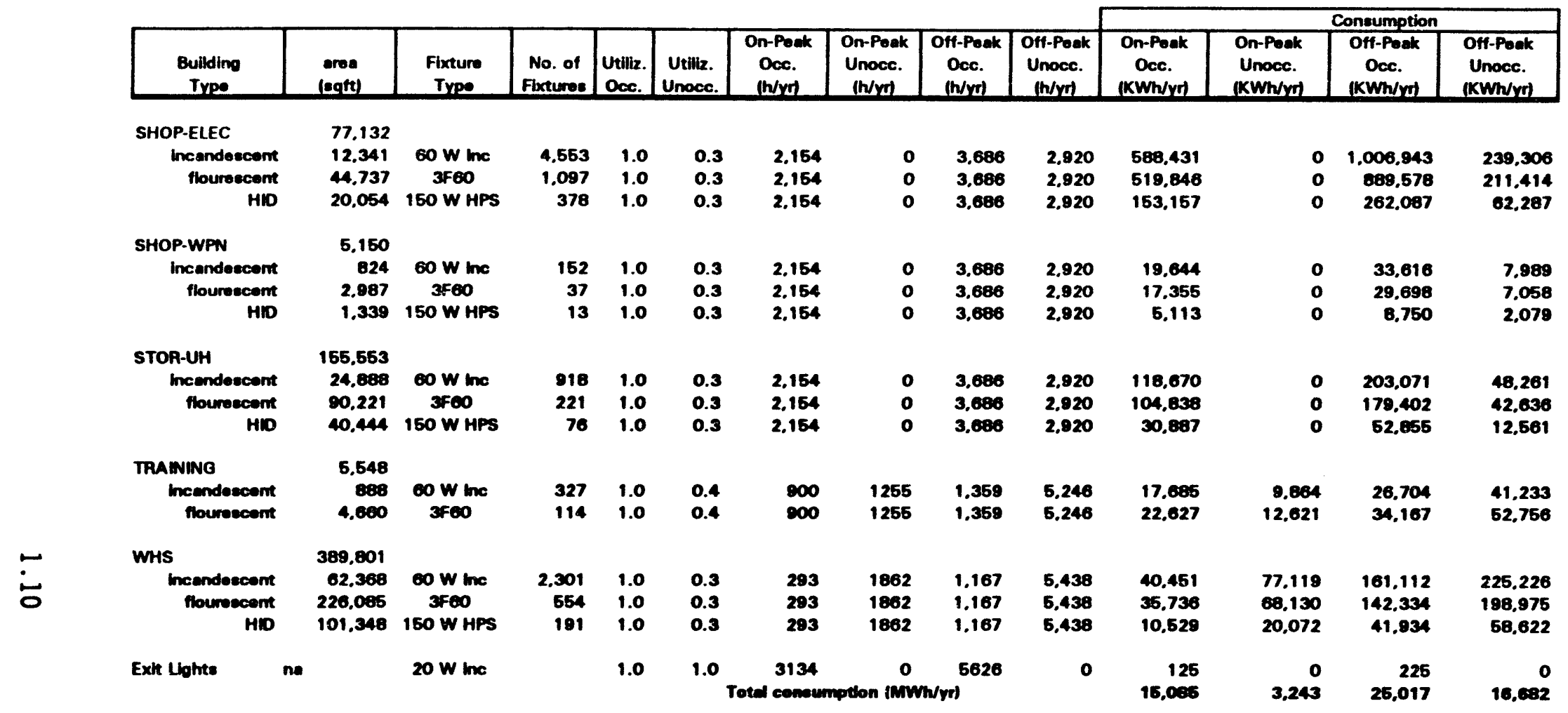


IABLE 1.5. Cape Canaveral AFS Boilers

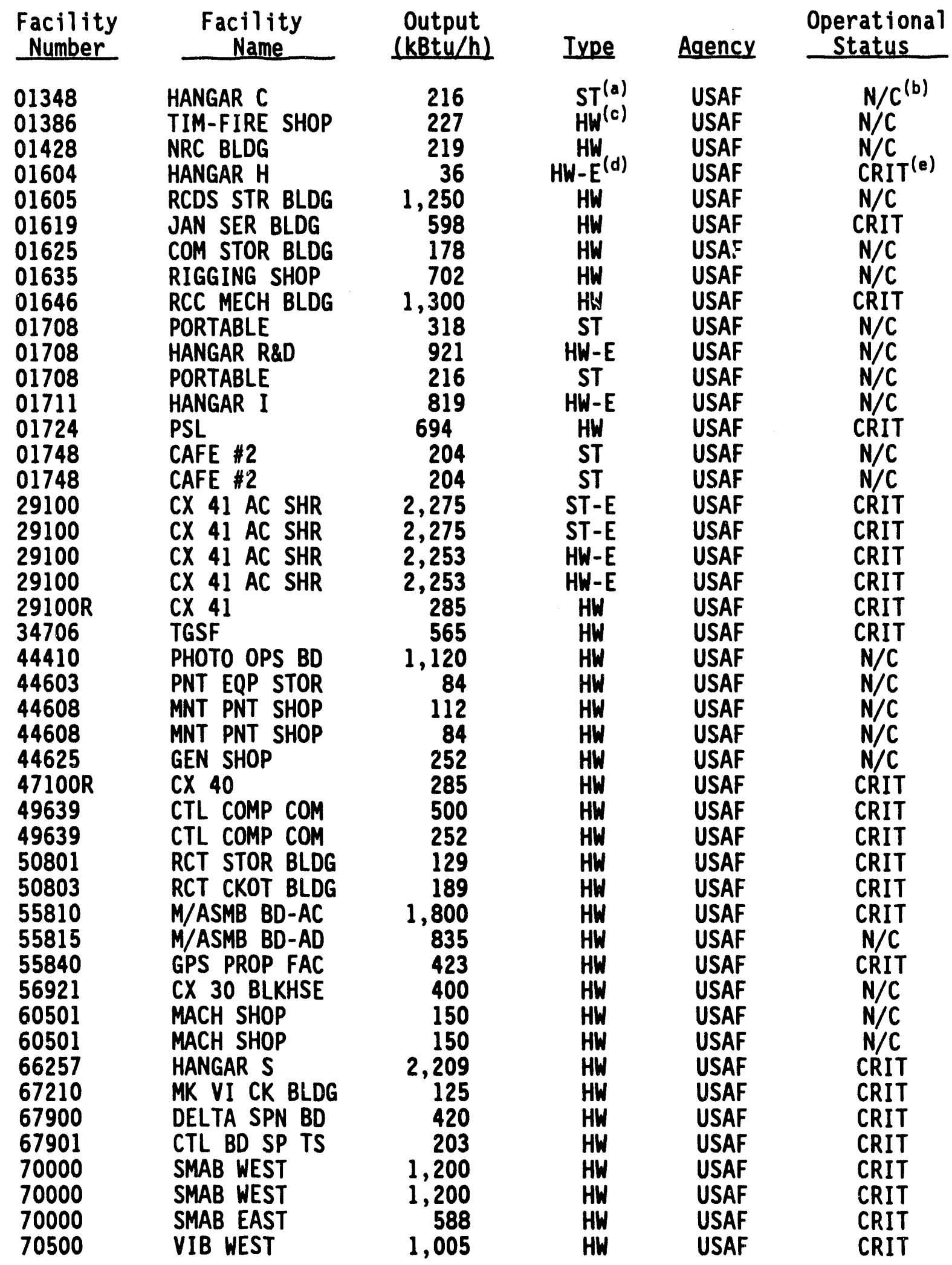


TABLE 1.5. (contd)

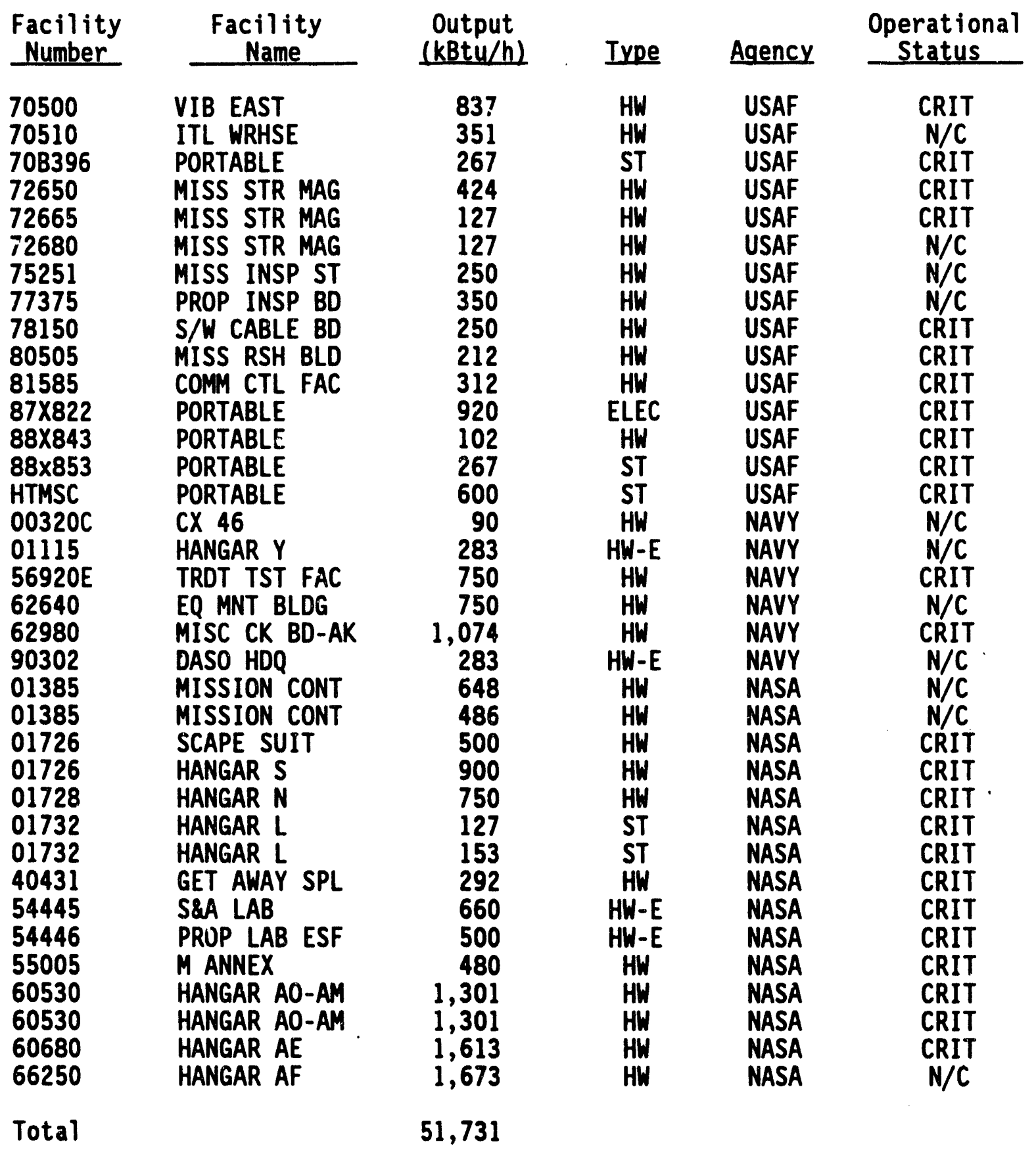
(a) Steam
(b) Noncritical
(c) Hot Water
(d) Hot Water-Electric
(e) Critical 
Table 1.6 summarizes the air-conditioning and refrigeration equipment at the station (PRAD Group 1992), as well as the correspanding energy consumption.

\subsubsection{Utility Characterization}

Cape Canaveral AFS Transformers

Table 1.7 lists the transformers found at Cape Canaveral AFS. A total of 814 transformers, with a total of 178,085 kVA, were identified (McCarthy 1992).

\subsubsection{Water Distribution Characterization}

Limited information regarding the water distribution system was available from the site.

\subsubsection{Sewage Treatment Characterization}

The main sewage treatment $p l a n t$ for Cape Canaveral AFS is located in the industrial area. The plant has a capacity to process $640 \mathrm{kgal} /$ day of sewage. The plant itself is comprised of a series of facilities that house various activities of the sewage treatment process. The largest facility is the settling bed followed by the control building. Other facilities include the lift station, chlorination facility, settling tank, digester building, trickling filter, pump house, and sludge drying bed.

\subsubsection{Exterior Lighting Characterization}

The exterior lighting data for Cape Canaveral AFS was gathered from information in a series of unpublished Johnson Controls' reports that provide a general description and location of the exterior lighting at the station. Because of specific information deficiencies in these documents, the following assumptions were made:

- If a lamp's wattage was not provided in the document, a standard size was assumed for each fixture type.

- The total number of exterior lights for the industrial area, Fuel Storage Area No. 1, and the Port Area were taken from a report on changes and elimination of lights because of the adverse effect on sea turtles. 
TABLE 1.6. Cape Canaveral AFS Air-Conditioning/Refrigeration Equipment

\begin{tabular}{|c|c|c|c|c|c|}
\hline Area & Description & $\begin{array}{l}\text { No. of } \\
\text { Units }\end{array}$ & $\begin{array}{l}\text { Total } \\
\text { Capacity } \\
\text { (tons) }\end{array}$ & $\begin{array}{l}\text { Energy Use } \\
\text { Off-Peak } \\
\text { (MWh/yr) } \\
\end{array}$ & $\begin{array}{c}\text { Energy Use } \\
\text { On-Peak } \\
\text { (MWh/yr) } \\
\end{array}$ \\
\hline Area 1 & $\begin{array}{l}\text { window unit } \\
\text { direct expansion* } \\
\text { Total }\end{array}$ & $\begin{array}{l}2 \\
1 \\
3\end{array}$ & $\begin{array}{r}3 \\
50 \\
53\end{array}$ & $\begin{array}{r}8 \\
64 \\
72\end{array}$ & $\begin{array}{r}12 \\
3,205 \\
3,216\end{array}$ \\
\hline Area $1 W$ & $\begin{array}{l}\text { window unit } \\
\text { chilled water } \\
\text { direct expansion } \\
\text { other } \\
\text { Total }\end{array}$ & $\begin{array}{r}8 \\
8 \\
51 \\
3 \\
70\end{array}$ & $\begin{array}{r}15 \\
1,365 \\
616 \\
105 \\
2,101\end{array}$ & $\begin{array}{r}154 \\
13,998 \\
40,271 \\
404 \\
54,827\end{array}$ & $\begin{array}{r}288 \\
2,388,414 \\
486,414 \\
14,133 \\
2,889,249\end{array}$ \\
\hline Area 2 & $\begin{array}{l}\text { window unit } \\
\text { chilled water } \\
\text { direct expansion } \\
\text { other } \\
\text { Total }\end{array}$ & $\begin{array}{r}6 \\
1 \\
13 \\
1 \\
21\end{array}$ & $\begin{array}{r}12 \\
120 \\
168 \\
1 \\
301\end{array}$ & $\begin{array}{r}92 \\
154 \\
2,800 \\
1 \\
3,047\end{array}$ & $\begin{array}{r}185 \\
18,459 \\
36,180 \\
1 \\
54,824\end{array}$ \\
\hline Area 3 & $\begin{array}{l}\text { chilled water } \\
\text { direct expansion } \\
\text { other } \\
\text { Total }\end{array}$ & $\begin{array}{r}2 \\
51 \\
5 \\
58\end{array}$ & $\begin{array}{r}210 \\
530 \\
10 \\
750\end{array}$ & $\begin{array}{r}538 \\
34,649 \\
64 \\
35,251\end{array}$ & $\begin{array}{r}56,531 \\
360,078 \\
128 \\
416,736\end{array}$ \\
\hline Area $3 A$ & $\begin{array}{l}\text { window unit } \\
\text { chilled water } \\
\text { direct expansion } \\
\text { other } \\
\text { Total }\end{array}$ & $\begin{array}{r}109 \\
32 \\
255 \\
33 \\
429\end{array}$ & $\begin{array}{r}213 \\
3,428 \\
2,660 \\
57 \\
6,358\end{array}$ & $\begin{array}{r}29,761 \\
140,616 \\
869,493 \\
2,411 \\
1,042,282\end{array}$ & $\begin{array}{r}58,157 \\
15,063,501 \\
9,070,006 \\
4,165 \\
24,195,829\end{array}$ \\
\hline Area 4 & $\begin{array}{l}\text { window unit } \\
\text { chilled water } \\
\text { direct expansion } \\
\text { other } \\
\text { Total }\end{array}$ & $\begin{array}{r}32 \\
1 \\
50 \\
4 \\
87\end{array}$ & $\begin{array}{r}48 \\
25 \\
537 \\
4 \\
614\end{array}$ & $\begin{array}{r}1,969 \\
32 \\
34,418 \\
21 \\
36,440\end{array}$ & $\begin{array}{r}2,953 \\
801 \\
369,652 \\
21 \\
373,427\end{array}$ \\
\hline Area 5 & $\begin{array}{l}\text { window unit } \\
\text { chilled water } \\
\text { direct expansion } \\
\text { other } \\
\text { Total }\end{array}$ & $\begin{array}{r}36 \\
6 \\
51 \\
15 \\
108\end{array}$ & $\begin{array}{r}67 \\
780 \\
622 \\
44 \\
1,513\end{array}$ & $\begin{array}{r}3,092 \\
5,999 \\
40,664 \\
846 \\
50,601\end{array}$ & $\begin{array}{r}5,754 \\
779,890 \\
495,935 \\
2,482 \\
1,284,062\end{array}$ \\
\hline Area 6 & $\begin{array}{l}\text { window unit } \\
\text { chilled water } \\
\text { direct expansion } \\
\text { other } \\
\text { Total }\end{array}$ & $\begin{array}{l}16 \\
7 \\
38 \\
11 \\
72\end{array}$ & $\begin{array}{r}27 \\
625 \\
291 \\
71 \\
1,014\end{array}$ & $\begin{array}{r}554 \\
5,608 \\
14,175 \\
1,001 \\
21,338\end{array}$ & $\begin{array}{r}934 \\
500,731 \\
108,550 \\
6,462 \\
616,677\end{array}$ \\
\hline
\end{tabular}


TABLE 1.6. (contd)

\begin{tabular}{|c|c|c|c|c|c|}
\hline Area & Description & $\begin{array}{l}\text { No. of } \\
\text { Units }\end{array}$ & $\begin{array}{l}\text { Total } \\
\text { Capacity } \\
\text { (tons) } \\
\end{array}$ & $\begin{array}{l}\text { Energy Use } \\
\text { Off-Peak } \\
\text { (MWh/yr) }\end{array}$ & $\begin{array}{c}\text { Energy Use } \\
\text { On-Peak } \\
\text { (MWh/yr) } \\
\end{array}$ \\
\hline Area 7 & $\begin{array}{l}\text { window unit } \\
\text { chilled water } \\
\text { direct expansion } \\
\text { other } \\
\text { Total }\end{array}$ & $\begin{array}{r}26 \\
4 \\
58 \\
3 \\
91\end{array}$ & $\begin{array}{r}33 \\
390 \\
788 \\
26 \\
1,237\end{array}$ & $\begin{array}{r}1,100 \\
2,000 \\
58,587 \\
100 \\
61,786\end{array}$ & $\begin{array}{r}1,396 \\
194,973 \\
795,970 \\
867 \\
993,205\end{array}$ \\
\hline Area 8 & $\begin{array}{l}\text { window unit } \\
\text { chilled water } \\
\text { direct expansion } \\
\text { other } \\
\text { Total }\end{array}$ & $\begin{array}{r}51 \\
2 \\
33 \\
14 \\
100\end{array}$ & $\begin{array}{r}81 \\
1,340 \\
345 \\
32 \\
1,798\end{array}$ & $\begin{array}{r}5,295 \\
3,435 \\
14,594 \\
574 \\
23,899\end{array}$ & $\begin{array}{r}8,410 \\
2,301,727 \\
152,575 \\
1,313 \\
2,464,025\end{array}$ \\
\hline IN & $\begin{array}{l}\text { window unit } \\
\text { chilled water } \\
\text { direct expansion } \\
\text { Total }\end{array}$ & $\begin{array}{r}5 \\
7 \\
11 \\
23\end{array}$ & $\begin{array}{r}8 \\
358 \\
200 \\
566\end{array}$ & $\begin{array}{r}51 \\
3,212 \\
2,820 \\
6,084\end{array}$ & $\begin{array}{r}82 \\
164,290 \\
51,275 \\
215,647\end{array}$ \\
\hline Other & $\begin{array}{l}\text { window unit } \\
\text { direct expansion } \\
\text { other } \\
\text { Total }\end{array}$ & $\begin{array}{r}1 \\
6 \\
5 \\
12\end{array}$ & $\begin{array}{r}2 \\
24 \\
5 \\
31\end{array}$ & $\begin{array}{r}3 \\
185 \\
32 \\
219\end{array}$ & $\begin{array}{r}5 \\
738 \\
32 \\
776\end{array}$ \\
\hline \multicolumn{2}{|c|}{$\begin{array}{l}\text { Total No. of Units: } \\
\text { Total Energy Consumption: }\end{array}$} & 1,074 & & $1,335,845$ & $33,507,673$ \\
\hline
\end{tabular}

Table 1.8 shows the quantity of each fixture type and its energy consumption corresponding to each area of the station.

Assumptions regarding hours of operation were based on information contained in the lighting management plans for the various areas at the station. The hours of operation were detailed for some fixtures. For those identified as occasional use, a use rate of 3 times a month for 1.10 hours was assumed. If no frequency of operation was given, the fixture was assumed to be operating every night for 10 hours, every day of the year. Some fixtures were identified to operate only during launches. Those fixtures were assumed to operate for 10 hours at night, 4 days per launch with an average of one launch per month. 
IABLE 1.7. Transformers at Cape Canaveral AFS

\begin{tabular}{|c|c|c|c|c|}
\hline $\begin{array}{c}\text { Total } \\
\text { Number }\end{array}$ & kVA & $\begin{array}{c}\text { Total } \\
\text { KVA } \\
\end{array}$ & $\begin{array}{l}\text { Primary } \\
\text { Voltage } \\
(\mathrm{kV}) \\
\end{array}$ & $\begin{array}{c}\text { Secondary } \\
\text { Voltage } \\
\text { (V) }\end{array}$ \\
\hline $\begin{array}{r}16 \\
16 \\
69 \\
68 \\
112 \\
3 \\
2 \\
40 \\
93 \\
90 \\
41 \\
5 \\
1 \\
7 \\
6 \\
50 \\
11 \\
11 \\
11 \\
18 \\
6 \\
3 \\
21 \\
34 \\
6 \\
23 \\
1 \\
21 \\
2 \\
1 \\
10 \\
3 \\
1 \\
10 \\
1 \\
1\end{array}$ & $\begin{array}{r}3 \\
5 \\
10 \\
15 \\
25 \\
25 \\
30 \\
37.5 \\
50 \\
75 \\
100 \\
112.5 \\
112.5 \\
150 \\
150 \\
167 \\
225 \\
225 \\
250 \\
300 \\
300 \\
333 \\
300 \\
500 \\
500 \\
750 \\
750 \\
1,000 \\
1,000 \\
1,125 \\
1,500 \\
1,500 \\
2,000 \\
2,500 \\
2,500 \\
3,000 \\
3,000\end{array}$ & $\begin{array}{r}48 \\
48 \\
690 \\
1,020 \\
2,800 \\
75 \\
60 \\
1,500 \\
4,650 \\
6,750 \\
4,100 \\
562.5 \\
112.5 \\
1,020 \\
900 \\
8,350 \\
2,475 \\
2,475 \\
2,750 \\
5,400 \\
1,800 \\
999 \\
10,500 \\
17,000 \\
4,500 \\
17,250 \\
1,000 \\
21,000 \\
2,250 \\
1,500 \\
15,000 \\
6,000 \\
2,500 \\
25,000 \\
3,000 \\
3,000\end{array}$ & $\begin{array}{l}13.2 \\
13.2 \\
13.2 \\
13.2 \\
13.2 \\
13.2 \\
13.2 \\
13.2 \\
13.2 \\
13.2 \\
13.2 \\
13.2 \\
13.2 \\
13.2 \\
13.2 \\
13.2 \\
13.2 \\
13.2 \\
13.2 \\
13.2 \\
13.2 \\
13.2 \\
13.2 \\
13.2 \\
13.2 \\
13.2 \\
13.2 \\
13.2 \\
13.2 \\
13.2 \\
13.2 \\
13.2 \\
13.2 \\
13.2 \\
13.2 \\
13.2\end{array}$ & $\begin{array}{l}208 \\
208 \\
208 \\
208 \\
208 \\
480 \\
208 \\
208 \\
208 \\
208 \\
208 \\
208 \\
480 \\
208 \\
480 \\
208 \\
208 \\
480 \\
208 \\
208 \\
480 \\
208 \\
208 \\
480 \\
208 \\
480 \\
208 \\
480 \\
208 \\
208 \\
480 \\
480 \\
208 \\
480 \\
208 \\
480\end{array}$ \\
\hline 814 & & 178,085 & & \\
\hline
\end{tabular}


IABLE 1.8. Exterior Lighting Fixtures and Corresponding Energy Consumption at Cape Canaveral AFS

\begin{tabular}{|c|c|c|c|c|}
\hline Area & $\begin{array}{c}\text { Fixture } \\
\text { Type }\end{array}$ & Quantity & $\begin{array}{l}\text { Watt } \\
\text { Draw }\end{array}$ & $\begin{array}{c}\text { Energy } \\
\text { Consumption } \\
\text { (kWh/yr) }\end{array}$ \\
\hline Industrial Area & $\begin{array}{l}75-W \text { Inc } \\
100-W \text { Inc } \\
150-W \text { Inc } \\
200-W \text { Inc } \\
250-W \text { Inc } \\
300-W \text { Inc } \\
500-W \text { Inc } \\
250-W \text { HPS } \\
300-W \text { HPS } \\
400-W \text { HPS } \\
1000-W \text { MV }(c) \\
500-W \text { Quartz }\end{array}$ & $\begin{array}{r}50 \\
83 \\
216 \\
23 \\
65 \\
61 \\
34 \\
20 \\
24 \\
182 \\
2 \\
10\end{array}$ & $\begin{array}{r}75 \\
100 \\
150 \\
200 \\
250 \\
300 \\
500 \\
305 \\
365 \\
465 \\
1,000 \\
500\end{array}$ & $\begin{array}{r}13,688 \\
30,295 \\
118,260 \\
16,790 \\
59,313 \\
66,795 \\
62,050 \\
22,265 \\
31,974 \\
308,900 \\
7,300 \\
18,250\end{array}$ \\
\hline Port Area & $\begin{array}{l}150-W \text { Inc } \\
35-W \text { HPS } \\
100-W \text { HPS } \\
150-W \text { HPS } \\
200-W \text { HPS } \\
400-W \text { MH } \\
1000-W \text { MV } \\
400-W \text { MV } \\
200-W \text { Quartz } \\
500-W \text { Quartz } \\
500-W \text { Quartz }\end{array}$ & $\begin{array}{r}3 \\
3 \\
14 \\
4 \\
51 \\
1 \\
40 \\
60 \\
1 \\
9 \\
3\end{array}$ & $\begin{array}{r}150 \\
54 \\
130 \\
188 \\
240 \\
460 \\
1,080 \\
460 \\
200 \\
500 \\
500\end{array}$ & $\begin{array}{r}1,643 \\
591 \\
6,643 \\
2,745 \\
44,676 \\
1,679 \\
157,680 \\
100,740 \\
730 \\
16,425 \\
5,475\end{array}$ \\
\hline Fuel Storage Area & $\begin{array}{l}150-W \text { Inc } \\
300-W \text { Inc } \\
35-W \text { HPS } \\
100-W \text { HPS } \\
100-W \text { LPS } \\
\text { 400-W MH } \\
1000-W \text { MH } \\
500-W \text { Quartz }\end{array}$ & $\begin{array}{r}14 \\
37 \\
175 \\
6 \\
52 \\
16 \\
30 \\
5\end{array}$ & $\begin{array}{r}150 \\
300 \\
55 \\
130 \\
135 \\
460 \\
1,000 \\
500\end{array}$ & $\begin{array}{r}7,665 \\
15,770 \\
29,200 \\
2,847 \\
19,850 \\
26,864 \\
14,400 \\
9,125\end{array}$ \\
\hline Launch Complex & $\begin{array}{l}300-W \text { Inc } \\
35-W \text { HPS } \\
100-W \text { LPS } \\
400-W \text { MV } \\
400-W \text { MH } \\
1000-W \text { MH } \\
500-W \text { Quartz }\end{array}$ & $\begin{array}{r}604 \\
1,433 \\
277 \\
65 \\
60 \\
471 \\
71\end{array}$ & $\begin{array}{r}300 \\
55 \\
135 \\
400 \\
400 \\
1,000 \\
500\end{array}$ & $\begin{array}{r}328,500 \\
84,900 \\
44,100 \\
24,600 \\
6,000 \\
155,300 \\
17,200\end{array}$ \\
\hline
\end{tabular}


IABLE 1.8. (contd)

\begin{tabular}{|c|c|c|c|c|c|}
\hline \multicolumn{2}{|c|}{ Area } & $\begin{array}{c}\text { Fixture } \\
\text { Type } \\
\end{array}$ & \multirow{2}{*}{$\begin{array}{r}\text { Quantity } \\
23 \\
15 \\
13\end{array}$} & \multirow{2}{*}{$\begin{array}{r}\text { Watt } \\
\text { Draw } \\
300 \\
55 \\
200\end{array}$} & \multirow{2}{*}{$\begin{array}{c}\begin{array}{c}\text { Energy } \\
\text { Consumption } \\
\text { (kwh/yr) }\end{array} \\
\begin{array}{c}25,185 \\
3,011 \\
9,490\end{array}\end{array}$} \\
\hline Vertic: & cal Integration Bldg & $\begin{array}{l}300-W \text { Inc } \\
35-W \text { HPS } \\
200-W \text { Quartz }\end{array}$ & & & \\
\hline Total C & Consumption (MWh/yr) & & & & 1,919 \\
\hline $\begin{array}{l}\text { (a) } \mathrm{Ir} \\
\text { (b) } \mathrm{Hi} \\
\text { (c) } \mathrm{Me} \\
\text { (d) } \mathrm{Me} \\
\text { (e) } \mathrm{Lc}\end{array}$ & $\begin{array}{l}\text { Incandescent } \\
\text { tigh-pressure sodium } \\
\text { lercury vapor } \\
\text { letal hal ide } \\
\text {-ow-pressure sodium }\end{array}$ & & & & \\
\hline
\end{tabular}




\subsection{ENERGY SOURCE CHARACTERISTICS}

Energy sources used by Cape Canaveral AFS include electricity, No. 2 fuel oil, diesel fuel, and motor vehicle gasoline (MOGAS). Table 2.1 provides information on the total energy consumption for these fuel types for 1991 and 1992. Diesel fuel is used to power portable generators, fork lifts, compressors, and some heavy vehicles. Fuel oil is used for boilers and MOGAS is used for both government and contractor vehicles. Information on electricity and No. 2 fuel oil energy use for 1992 was not available. However, 1991 data indicate that greater than $60 \%$ of the total energy usage was electricity, with the next highest being diesel fuel. The lowest amount of energy use was for motor vehicles.

\subsection{ELECTRIC SUPPLY SOURCE DESCRIPTION}

Electricity is supplied to Cape Canaveral AFS by Florida Power \& Light (FPL) through three $115 \mathrm{kV}$ lines. Three electric metering points are the North, South, and Titan Substations. From each substation, distribution is

TABLE 2.1. Typical Annual Energy Consumption and Energy Costs at Cape Canaveral AFS for 1991 and 1992

\begin{tabular}{|c|c|c|c|c|c|c|c|}
\hline \multirow{3}{*}{$\begin{array}{l}\text { Eneroy Type } \\
\text { Electricity(b) }\end{array}$} & \multicolumn{3}{|c|}{ Annual Total } & \multirow{2}{*}{\multicolumn{2}{|c|}{$\begin{array}{c}\text { Annual Total } \\
(\mathrm{MB} B \mathrm{~B})^{(\mathbf{1})}\end{array}$}} & \multirow{3}{*}{$\begin{array}{c}\begin{array}{c}\text { Percent } \\
\text { of Total } \\
\text { J19911 }\end{array} \\
61.5\end{array}$} & \multirow{3}{*}{$\begin{array}{c}\text { Energy Cost } \\
\text { (1991 \$, in } \\
\text { thousands) } \\
9,876\end{array}$} \\
\hline & 1991 & 1992 & Units & & & & \\
\hline & $192,074.0$ & NA & $M W h^{(0, d)}$ & 655,549 & NA & & \\
\hline No. 2 Fuel Oil & 924.1 & NA & kgal|(o) & 128,265 & NA & 12.0 & 952 \\
\hline Diesel Fuel ${ }^{1 n}$ & 1558.3 & 1705.7 & $\mathrm{kgal}^{(0)}$ & 218,162 & 238,798 & 20.5 & 1,558 \\
\hline MOGAS & 502.4 & 508.6 & kgal ${ }^{(n)}$ & 63,805 & 64,592 & 6.0 & 619 \\
\hline Total & & & & $1,065,781$ & & 100.0 & 13,005 \\
\hline
\end{tabular}
(a) $1 \mathrm{MBtu}=1,000,000 \mathrm{Btu}$
(b) Florida Power \& Light Billing Records
(c) Defense Energy Information System Records
(d) $1 \mathrm{MWh}=3,413,000 \mathrm{Btu}$
(e) $1 \mathrm{kgal}=138.8 \mathrm{MBtu}$
(f) Cape Canaveral AFS personnel
(g) $1 \mathrm{kgal}=140.0 \mathrm{MBtu}$
(h) $1 \mathrm{kgal}=127.0 \mathrm{MBtu}$ 
made to substations owned by the USAF and then distributed through $13.2 \mathrm{kV}$ feeder circuits. Although some underground circuits exist, the primary mode of distribution is through overhead lines to the various facilities and launch sites.

Electricity supplied by FPL is billed under a time-of-use rate structure designated as General Service Large Demand Time-of-Use (GSLDT-3). The on-peak periods are from 6:00 a.m. to 10:00 a.m. and 6:00 p.m. to 10:00 p.m. for November 1 through March 31, and 12:00 noon to 9:00 p.m. from Apri1 1 through October 31. The rate in effect in 1991 consisted of a customer charge of $\$ 400$ and an on-peak demand charge of $56.25 / \mathrm{kW}$. An on-peak energy and fuel charge of $\$ 0.01082 / \mathrm{kWh}$ and $\$ 0.02175 / \mathrm{kWh}$, respectively, and an off-peak energy and fuel charge of $\$ 0.0949 / \mathrm{kWh}$ and $\$ 0.01975 / \mathrm{kWh}$, respectively, were included. An 011 backout charge of $\$ 0.00651 / \mathrm{kWh}$ and a conservation charge of $\$ 0.00135 / \mathrm{kWh}$ were included in the electric bill. Table 2.2 summarizes the above information.

There is no central generation plant at Cape Canaveral AFS. However, there are portable backup generators for critical facilities and pump stations that are powered by diesel fuel and typically operate less than $100 \mathrm{~h} / \mathrm{yr}$.

\subsection{DIESEL/FUEL OIL SUPPLY SOURCE DESCRIPTION}

Diesel fuel is used to power portable electric generators for standby power during launch periods at the station. Fuel oil is used for limited

IABLE 2.2. Cape Canaveral AFS Electric Rate Structure Breakdown - 1991

\begin{tabular}{|c|c|c|c|c|c|c|c|c|}
\hline Seevon & $\begin{array}{l}\text { Rate } \\
\text { Type }\end{array}$ & $\begin{array}{c}\text { Houre of } \\
\text { Der }\end{array}$ & $\begin{array}{l}\text { Demend } \\
\text { Charee } \\
(1 \mathrm{~kW}) \\
\end{array}$ & $\begin{array}{l}\text { Enorey } \\
\text { Chareo } \\
\text { (G/kWh! }\end{array}$ & $\begin{array}{l}\text { Funt } \\
\text { Charese } \\
\text { (e/kWh) }\end{array}$ & $\begin{array}{c}\text { On Backout } \\
\text { Charge } \\
\text { (E/kWhL } \\
\end{array}$ & $\begin{array}{c}\text { Conservation } \\
\text { Charge } \\
\text { (c/kWh) } \\
\end{array}$ & $\begin{array}{c}\text { Totel } \\
\text { Energy } \\
\text { (E/kWh) }\end{array}$ \\
\hline Winter & On-Panak & 6:00 am-10:00 $\mathrm{cm}$ & 6.25 & 1.082 & 2.176 & 0.651 & 0.135 & 4.043 \\
\hline \multirow[t]{4}{*}{ (Nov. 1-March 31) } & & 6:00pm-10:00pm & 6.26 & 1.082 & 2.175 & 0.651 & 0.135 & 4.043 \\
\hline & Ott-Poak & 12:00 am-6:00 $\mathrm{cm}$ & 0.00 & 0.040 & 1.075 & 0.651 & 0.135 & 3.71 \\
\hline & & 10:00 m-6:00pm & 0.00 & 0.849 & 1.075 & 0.651 & 0.135 & 3.71 \\
\hline & & 10:00pm-12:00em & 0.00 & 0.849 & 1.075 & 0.651 & 0.135 & 3.71 \\
\hline Summer & On-Puak & 12:00pm-8:00pm & 6.26 & 1.082 & 2.176 & 0.651 & 0.136 & 4.043 \\
\hline (April 1-Oct.31) & OH-Poek & 0:00pm-12:00pm & 0.00 & 0.840 & 1.075 & 0.651 & 0.135 & 3.71 \\
\hline
\end{tabular}


space and water heating through the oil-fired hot water or steam boilers listed in Table 1.5. During summer months, reheat is used in some buildings as part of the air-conditioning/dehumidification system. In CY91, Cape Canaveral AFS purchased 22,002 barrels of No. 2 fuel o11 $(128,262 \mathrm{MBtu})$ at a price of $\$ 1.03 /$ gal for a total cost of $\$ 951,806$.

Cape Canaveral AFS maintains several mobile electric power (MEP) generators for use as backup power in launch situations or when a building's power supply must be interrupted for maintenance reasons. The MEPs are not assigned to specific facilities, but are kept in a central location and moved to sites as they are required. All MEPs are fueled by diesel. No information was available concerning MEP hours of operation. Table 2.3 1ists the number, output (kilowatt), and fuel consumption rate of the generators.

\subsection{VEHICLE GASOLINE/DIESEL SUPPLY SOURCE DESCRIPTION}

Fuels for motor vehicles at Cape Canaveral AFS are supplied through Rayethon Services. In FY91, the station vehicles consumed 503,079 gal of unleaded regular gasoline at a cost of $\$ 1.23 / 9 a l$, for a total cost of $\$ 618,787$. During the same period, $1,512,718$ gal of diesel fuel were consumed at $\$ 1.03 / \mathrm{gal}$, for a total cost of $\$ 1,558,099$. Table 2.4 lists the total number of vehicles used at the station.

IABLE 2.3. Cape Canaveral AFS Mobile Electric Power Generators

\begin{tabular}{|c|c|c|}
\hline $\begin{array}{l}\text { Number of } \\
\text { Generators }\end{array}$ & $\begin{array}{c}\text { Output } \\
\text { (kWI) }\end{array}$ & $\begin{array}{l}\text { Fuel Consur } \\
\text { Rate (q }\end{array}$ \\
\hline 16 & 15 & 2.6 \\
\hline 19 & 30 & 3.3 \\
\hline 17 & 100 & 8.7 \\
\hline 9 & 150 & 13.3 \\
\hline 7 & 200 & 30.0 \\
\hline 2 & 300 & 20.0 \\
\hline 1 & 350 & 29.0 \\
\hline 1 & 500 & 17.0 \\
\hline
\end{tabular}




\begin{tabular}{|c|c|c|}
\hline $\begin{array}{l}\text { Number of } \\
\text { Yehtcles }\end{array}$ & $\begin{array}{c}\text { Vehicle } \\
\text { Descriotion }\end{array}$ & $\begin{array}{l}\text { Fuel } \\
\text { Iype }\end{array}$ \\
\hline 9 & Sedan & $G^{(a)}$ \\
\hline 2 & Bus & $D^{(b)}$ \\
\hline 1 & Station Wagon & $\mathbf{G}$ \\
\hline 24 & Panel Truck & $G$ \\
\hline 4 & Multistop (van) & G \\
\hline 68 & Multistop (van) & D \\
\hline 24 & Carry-AII & G \\
\hline 288 & Pickup & G \\
\hline 4 & Pickup & D \\
\hline 7 & Stake \& Platform Cargo & G \\
\hline 29 & Stake \& Platform Cargo & D \\
\hline 2 & Winch Truck & G \\
\hline 9 & Truck/Tractor & D \\
\hline 45 & Telephone M & \\
\hline
\end{tabular}
(a) Gasoline
(b) Diesel

\subsection{NATURAL-GAS SUPPLY SOURCE DESCRIPTION}

Currently, natural gas is not supplied to Cape Canaveral AFS. Gas is available at KSC to the west and Port Canaveral to the south. The supplier of natural gas in the region, City Gas of Florida, has expressed an interest in running a pipeline through Cape Canaveral AFS to connect KSC and Port Canaveral. If this occurs, gas can be made available to individual facilities for gas-driven chillers, boilers, water heating, as well as to power generation facilities. 


\subsection{ENERGY-USE INTENSITIES}

Energy-use intensity (EUI) values are used to help develop baseline consumption for various building types when metered data is not available. This section describes the regional and site-specific EUI information that was gathered for use in the energy assessment at Cape Canaveral AFS. Tables A.1 to A.19 in the Appendix display the basic regional EUI information that was collected. These data provided reasonable EUI values from which site-specific values could be determined. Calculation of site-specific EUIs is described in more detail in the following sections.

\subsection{REGIONAL ENERGY-USE DATA SOURCES}

Energy-use intensities are defined as energy use per unit floor area, per unit time. EUIs are commonly expressed as thousands of British thermal units per square foot per year (kBtu/ftz-yr), or kilowatt-hours per square foot per year $\left(k W h / \mathrm{ft}^{2}-\mathrm{yr}\right)$.

Tables A.1 through A.19 break out regional energy use by facility type, building type, fuel type, and fuel end use. Energy use is expressed in kilowatt-hours per square foot per year for electric EUIs and thousands of British thermal units per square foot per year for fossil fuel EUIs. Energyuse data are reported for the following end-use categories: space heating, cooling, ventilation, domestic hot water (DHW), cooking, lighting (includes interior and exterior), refrigeration, and other. The category entitled "other" includes miscellaneous end uses made up of a variety of electrical appliances and motors, as well as water and steam heating for laundry and food preparation.

A primary product of the regional energy consumption analysis for Cape Canaveral AFS is site-specific EUI values for various building types and end uses that make up the energy consumption at the station. These EUI values are considered reasonable representations of the magnitude of energy consumption among various end uses and buildings. 


\subsection{SITE-SPECIFIC ENERGY-USE VALUES}

As shown in Table 3.1, several users reimburse the USAF for electricity consumed by the users. The table shows typical annual consumption (CY91) for reimbursable facilities at the station. The consumption values are metered for each facility. NASA is billed for the facilities shown below as "NASA" in the column entitled "Agency, " plus 5.12\% of the nonreimbursable electricity consumption. Nonreimbursable consumption is defined as the total Cape Canaveral AFS electricity consumption minus the reimbursable accounts shown in Table 3.1.

The final step in EUI development was completed as part of the final allocation of energy process. This process incorporates various factors that influence energy consumption, and thus EUIs, among buildings. These factors include weather, occupancy, construction, age, operation, and function. Sometimes actual building metering data or single-building type area metering provided an exact whole-building EUI for a particular building type. Otherwise, EUI values were derived by an energy balance method. This method accounts for all energy use at the station and apportions it as accurately as possible among the building types and other uses. Table 3.2 summarizes the EUI information at the station. 
IABLE 3.1. Cape Canaveral AFS Reimbursable Electricity Consumption - 1991

\begin{tabular}{|c|c|c|c|c|}
\hline Facility & Number & Meters & $k W h / Y r$ & Agency \\
\hline APOLLO WAREHOUSE & 66330 & 1 & 184,600 & NASA \\
\hline AREA $60 \mathrm{~A}$ & 59921 & 1 & $2,324,800$ & NASA \\
\hline COMPLEX 19 SUBSTATION & 15730 & 1 & 95,450 & NASA \\
\hline COMPLEX 34 & 21900 & 2 & $1,050,800$ & NASA \\
\hline DISPENSARY & 49635 & 1 & 876,720 & NASA \\
\hline E\&O BUILDING & 60650 & 3 & 984,960 & NASA \\
\hline HANGAR AE & 60680 & 3 & $2,613,492$ & NASA \\
\hline HANGAR AF & 66250 & 2 & $3,782,400$ & NASA \\
\hline HANGAR AM & 60550 & 2 & $1,693,800$ & NASA \\
\hline HANGAR AO & 60530 & 2 & $3,378,600$ & NASA \\
\hline HANGAR L & 1732 & 3 & $3,942,744$ & NASA \\
\hline HANGAR N & 1728 & 2 & 650,360 & NASA \\
\hline HANGAR $S$ & 1726 & 4 & $1,708,520$ & NASA \\
\hline HERF & 67400 & 1 & 324,130 & NASA \\
\hline M ANNEX & 55005 & 1 & 362,000 & NASA \\
\hline MISSILE INSP \& STORAGE & 60680 & 1 & 619,800 & NASA \\
\hline MISSION CONTROL & 1385 & 1 & 731,440 & NASA \\
\hline PASSIVATION BUILDING & 66220 & 1 & 417,840 & NASA \\
\hline SRB PAINT FACILITY & 66310 & 1 & 855,040 & NASA \\
\hline COMPLEX 17 & 1270 & 5 & $4,423,520$ & $\operatorname{ASTG}^{(a)}$ \\
\hline COMPLEX 36 & 5500 & 1 & $3,157,200$ & ASTG \\
\hline CPOCC II & 27200 & 1 & $3,221,280$ & ASTG \\
\hline DELTA SPIN TEST & 6790 & 1 & $11,165,536$ & ASTG \\
\hline DSIF & $27200 A$ & 1 & 333,160 & ASTG \\
\hline E\&L BUILDING & 1704 & 3 & $1,257,780$ & ASTG \\
\hline HANGAR J & 1721 & 3 & 880,120 & ASTG \\
\hline HANGAR $\mathrm{K}$ & 1725 & 2 & $1,044,540$ & ASTG \\
\hline HANGAR M & 1731 & 2 & 182,200 & ASTG \\
\hline NASA SUPPORT & $1305 A$ & 4 & 680,970 & ASTG \\
\hline NAVSTAR PROCESSING FACILITY & 55810 & 1 & $2,790,000$ & ASTG \\
\hline COMMERCIAL TITAN FACILITY & 55038 & 1 & 43,760 & $\operatorname{TITN}^{(b)}$ \\
\hline COMPLEX 30 & 56920 & 3 & 614,747 & NOTU $^{(c)}$ \\
\hline COMPLEX 46 SUPPORT BUILDING & 320 & 2 & $1,437,720$ & NOTU \\
\hline DASO SUPPORT BUILDING & 90302 & 1 & 944,800 & NOTU \\
\hline NAVY STORAGE BUILDING & 85200 & 1 & 38,178 & NOTU \\
\hline NAVY TRAINING BUILDING & 54815 & 1 & 480,000 & NOTU \\
\hline NAVY VEHICLE MAINT FACILITY & 81701 & 1 & 214,400 & NOTU \\
\hline NOTU GTB & 62700 & 1 & 148,080 & NOTU \\
\hline SOUTHSUB COM & & 1 & $12,451,200$ & NOTU \\
\hline
\end{tabular}


TABLE 3.1. (contd)

Faciiity

SOUTH SUBSTATION TRIDENT BASIN

TEST OPS FACILITY

COMPLEX 20

FLORIDA SOLAR ENERGY CENTER

FUEL STORAGE AREA

U.S.C.G. ARMORY

COMPLEX 36

MODULAR BUILDING
Number Meter

$\begin{array}{rl}62615 & 1 \\ 18807 & 3 \\ & 3 \\ 1221 & 1 \\ 1381 & 1 \\ 5500 & 1 \\ 55101 & 1\end{array}$

kWh/Yr Agency

$5,320,800$ NOTU

$2,066,880$ NOTU

542,168 ARMY

668,700 FSEC $^{(d)}$

$5,916 \quad C^{(e)}$

$71,301 \quad C G$

$3,157,200 \quad G^{(f)}$

138,803 GD

(a) Air Support Testing Group

(b) Commercial Titan

(c) Naval Ordnance Test Unit

(d) Florida Solar Energy Center

(e) U.S. Coast Guard

(f) General Dynamics 
IABLE 3.2. Cape Canaveral AFS EUI Information

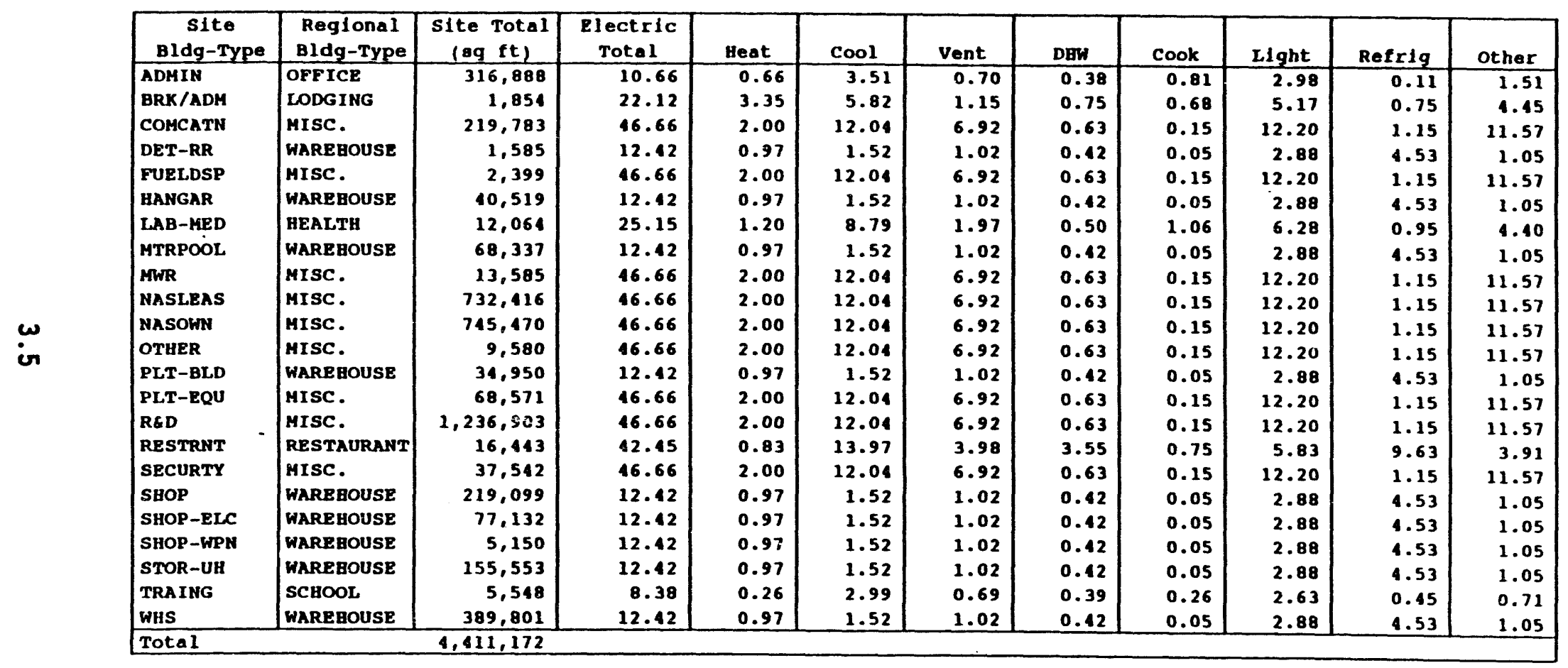

All values are $\mathrm{kwh} / \mathrm{sq} \mathrm{ft}-\mathrm{yr}$ unless otherwise noted 


\subsection{ELECTRICAL CONSUMPTION}

\subsection{METERING AND DATA SUMMARY}

There were two sources of electrical consumption data at Cape Canaveral AFS: utility company whole-substation meter readings and the information contained in Defense Energy Information System (DEIS) reports. The DEIS reports are based on total billing records and include reimbursable account information.

For each substation, a kilowatt-hour meter and a demand register are installed. Fifteen-minute demand readings are recorded from which the highest demand reading for the on-peak period can be determined. Tables 4.1 through 4.21 provide a summary of FPL metered data for the North, South, and Titan Substations from 1985 (base year for energy reduction requirements) through 1991. These tables provide information on kilowatt-hours for on-peak and offpeak hours, total kilowatt-hours, maximum kilowatt demand for the respective month, and the load factor.

Electrical consumption data obtained from DEIS records for each month for the period of January 1985 through December 1991 are provided in Figure 4.1. This summary data includes consumption by reimbursable usage by NASA, the U.S. Coast Guard, and other non-SPACECOM users. The primary purpose of Table 4.1 is to identify trends in consumption at the station. For the period of 1985 through 1988, the consumption pattern is similarly shaped. After that period, however, there is a steady trend in increasing consumption.

Figure 4.2 shows the station's total energy consumption by month for 1991. However, consumption data is categorized by major end users. The major reimbursable accounts are NASA, the U.S. Navy, and the 6555th Airspace Test Group. The amount of monthly consumption is determined by direct metering or previously agreed to rates based on a percentage of the total bill. 


\subsection{ENERGY-USE BREAKDOWN}

The electrical consumption for Cape Canaveral AFS is shown in Table 4.22. Each building type and utility service is listed individually, as well as being grouped by site area or service. The consumption is apportioned within each building type to each of its primary end uses. Also included for each end use is the number and square footage of the buildings within each type that use electricity for that end use. The electrical end uses that are not tied to a specific building type (e.g., street lights) are shown with totals only. A value for the transmission and distribution loss throughout the electrical-distribution system is also shown.

\subsection{LOAD PROFILE}

Florida Power \& Light provided representative load profile information for the North, South, and Titan Substations for the four seasons of the year. For each season, data was provided for two different day types: weekday (generally Wednesday) and weekend data (Saturday). Fifteen-minute data was used to develop the profiles so that kilowatt-demand information was available for each hour of the day. By analyzing this data, a better idea could be gained regarding the peak saving or conservation potential at the station.

The data for all three substations were plotted on the same graph and are represented in Figures 4.3 through 4.10. Some seasonal differences are obvious, such as the demand being less in the winter compared to the other seasons. However, for all seasons the profiles for the Titan and South Substations are relatively flat, whereas the North Substation has more "peakness" in its profile, especially during workdays. This peakness is expected because the industrial area at Cape Canaveral AFS is served by the North Substation. Each substation has a high baseline demand over all hours of the day, indicating a considerable amount of end-use equipment that operates continuously. The site appears to be a candidate for both conservation and demand-side management activities. 
IABLE 4.1. Florida Power \& Light Electric Meter Readings North Substation - 1985

$\begin{array}{lrrrrrr}\text { Month } & \text { kWh On-Peak } & \text { kWh Off-Peak } & \text { Total kWh } & \begin{array}{c}\text { Maximum } \\$\cline { 6 - 7 } \text {$kWmand }\end{array} & \text { Load Factor } \\ \text { JAN } & 1,127,131 & 3,652,623 & 4,779,754 & -- & -- \\ \text { FEB } & 1,039,707 & 3,345,093 & 4,384,800 & 9,374 & 62.9 \% \\ \text { MAR } & 1,142,470 & 3,351,530 & 4,494,000 & 9,495 & 68.0 \% \\ \text { APR } & 1,515,931 & 3,658,469 & 5,174,400 & 9,909 & 72.5 \% \\ \text { MAY } & 1,599,905 & 3,448,495 & 5,048,400 & 11,713 & 61.9 \% \\ \text { JUN } & 1,777,101 & 4,010,499 & 5,787,600 & 11,330 & 70.9 \% \\ \text { JUL } & 1,653,599 & 3,831,601 & 5,485,200 & 11,174 & 68.2 \% \\ \text { AUG } & 1,818,165 & 4,297,035 & 6,115,200 & 11,385 & 69.9 \% \\ \text { SEP } & 1,730,295 & 4,057,305 & 5,787,600 & 11,516 & 69.8 \% \\ \text { OCT } & 1,880,976 & 4,116,624 & 5,997,600 & 11,663 & 71.4 \% \\ \text { NOV } & 1,345,871 & 3,710,929 & 5,056,800 & 11,148 & 61.0 \% \\ \text { DEC } & 1,296,240 & 4,146,960 & 5,443,200 & 11,164 & 65.5 \% \\ \text { TOTALS } & 17,927,391 & 45,627,163 & 63,554,554 & & \end{array}$

IABLE 4.2. Florida Power \& Light Electric Meter Readings South Substation - 1985

\begin{tabular}{|c|c|c|c|c|c|}
\hline Month & kwh On-Peak & kWh off-Peak & Iotal kWh & $\begin{array}{c}\text { Maximum } \\
\text { kW Demand }\end{array}$ & Load Factor \\
\hline JAN & 517,623 & $1,758,126$ & $2,275,749$ & -- & -- \\
\hline FEB & 581,241 & $1,871,559$ & $2,452,800$ & 6,223 & $53.0 \%$ \\
\hline MAR & 560,223 & $1,690,977$ & $2,251,200$ & 5,299 & $61.0 \%$ \\
\hline APR & 511,787 & $1,173,813$ & $1,685,600$ & 5,944 & $39.4 \%$ \\
\hline MAY & 777,815 & $1,910,185$ & $2,688,000$ & 6,757 & $57.2 \%$ \\
\hline JUN & 777,815 & $3,170,185$ & $3,948,000$ & 8,985 & $61.0 \%$ \\
\hline JUL & 928,191 & $2,387,009$ & $3,315,200$ & 8,282 & $55.6 \%$ \\
\hline AUG & $1,064,969$ & $2,933,431$ & $3,998,400$ & 8,256 & $63.1 \%$ \\
\hline SEP & 989,456 & $2,465,744$ & $3,455,200$ & 8,299 & $57.8 \%$ \\
\hline OCT & $1,032,454$ & $2,501,146$ & $3,533,600$ & 7,654 & $64.1 \%$ \\
\hline NOV & 878,306 & $2,918,494$ & $3,796,800$ & 7,668 & $66.6 \%$ \\
\hline DEC & 698,195 & $2,303,405$ & $3,001,600$ & 5,920 & $68.1 \%$ \\
\hline TOTALS & $9,318,075$ & $27,084,074$ & $36,402,149$ & & \\
\hline
\end{tabular}


IABLE 4.3. Florida Power \& Light Electric Meter Readings Titan Substation - 1985

\begin{tabular}{lrrrrrr} 
Month & kWh On-Peak & kWh 0ff-Peak & Total kWh & $\begin{array}{c}\text { Maximum } \\
\text { kW Demand }\end{array}$ & Load Factor \\
\cline { 7 - 7 } JAN & 290,504 & $1,008,426$ & $1,298,930$ & - & - \\
FEB & 309,985 & $1,028,415$ & $1,338,400$ & 2,396 & $75.1 \%$ \\
MAR & 342,246 & $1,040,954$ & $1,383,200$ & 2,644 & $75.2 \%$ \\
APR & 420,270 & $1,046,930$ & $1,467,200$ & 2,762 & $73.8 \%$ \\
MAY & 457,152 & $1,099,648$ & $1,556,800$ & 3,034 & $73.7 \%$ \\
JUN & 301,102 & 751,698 & $1,052,800$ & 2,785 & $52.5 \%$ \\
JUL & 473,819 & $1,217,381$ & $1,691,200$ & 3,387 & $69.4 \%$ \\
AUG & 692,845 & $1,855,155$ & $2,548,000$ & 4,324 & $76.7 \%$ \\
SEP & 670,058 & $1,743,542$ & $2,413,600$ & 4,106 & $81.6 \%$ \\
OCT & 667,234 & $1,628,766$ & $2,296,000$ & 3,955 & $80.6 \%$ \\
NOV & 537,064 & $1,658,136$ & $2,195,200$ & 3,756 & $78.6 \%$ \\
DEC & 328,485 & $1,065,915$ & $1,394,400$ & 3,427 & $54.7 \%$ \\
TOTALS & $5,490,764$ & $15,144,966$ & $20,635,730$ & &
\end{tabular}

TABLE 4.4. Florida Power \& Light Electric Meter Readings North Substation - 1986

$\begin{array}{lrrrrrr}\text { Month } & \text { kWh On-Peak } & \text { kWh 0ff-Peak } & \text { Tota] kWh } & \begin{array}{c}\text { Maximum } \\ \text { kW Demand }\end{array} & \text { Load Factor } \\ \text { JAN } & 1,174,635 & 3,806,565 & 4,981,200 & 9,208 & 69.3 \% \\ \text { FEB } & 1,159,225 & 3,410,375 & 4,569,600 & 9,395 & 69.4 \% \\ \text { MAR } & 1,150,342 & 3,402,458 & 4,552,800 & 10,226 & 60.2 \% \\ \text { APR } & 1,475,163 & 3,371,637 & 4,846,800 & 10,584 & 63.6 \% \\ \text { MAY } & 1,614,660 & 4,063,740 & 5,678,400 & 11,562 & 63.9 \% \\ \text { JUN } & 1,697,144 & 3,830,056 & 5,527,200 & 11,910 & 66.7 \% \\ \text { JUL } & 1,708,461 & 3,919,330 & 5,627,791 & 11,708 & 66.8 \% \\ \text { AUG } & 1,809,930 & 4,389,270 & 6,199,200 & 11,557 & 69.8 \% \\ \text { SEP } & 1,884,290 & 4,466,110 & 6,350,400 & 12,524 & 70.4 \% \\ \text { OCT } & 1,950,299 & 4,358,101 & 6,308,400 & 12,645 & 71.7 \% \\ \text { NOV } & 1,553,192 & 4,570,408 & 6,123,600 & 12,172 & 65.5 \% \\ \text { DEC } & 1,371,666 & 4,474,734 & 5,846,400 & 11,113 & 68.6 \% \\ \text { TOTALS } & 18,549,007 & 48,062,784 & 66,611,791 & & \end{array}$


IABLE 4.5. Florida Power \& Light Electric Meter Readings South Substation - 1986

$\begin{array}{lrrrrrr}\text { Month } & & \text { kWh On-Peak } & \text { kWh Off-Peak } & \text { Total kWh } & \begin{array}{c}\text { Maximum } \\ \text { kWl Demand }\end{array} & \text { Load Factor } \\ \text { JAN } & 671,256 & 2,279,944 & 2,951,200 & 6,072 & 63.3 \% \\ \text { FEB } & 769,182 & 2,411,618 & 3,180,800 & 6,458 & 70.8 \% \\ \text { MAR } & 757,841 & 2,333,359 & 3,091,200 & 7,768 & 57.2 \% \\ \text { APR } & 1,016,010 & 2,579,190 & 3,595,200 & 8,306 & 60.1 \% \\ \text { MAY } & 1,006,056 & 2,734,744 & 3,740,800 & 7,513 & 64.8 \% \\ \text { JUN } & 989,495 & 2,342,505 & 3,332,000 & 6,948 & 68.9 \% \\ \text { JUL } & 1,111,992 & 2,724,008 & 3,836,000 & 7,661 & 69.5 \% \\ \text { AUG } & 1,210,675 & 3,174,125 & 4,384,800 & 7,970 & 71.6 \% \\ \text { SEP } & 1,179,106 & 2,942,494 & 4,121,600 & 9,838 & 58.2 \% \\ \text { OCT } & 1,061,893 & 2,650,907 & 3,712,800 & 7,775 & 68.6 \% \\ \text { NOV } & 1,007,726 & 3,046,674 & 4,054,400 & 9,001 & 58.7 \% \\ \text { DEC } & 920,249 & 2,904,551 & 3,824,800 & 8,195 & 62.7 \% \\ \text { TOTALS } & 11,701,481 & 32,124,119 & 43,825,600 & & \end{array}$

TABLE 4.6. Florida Power \& Light Electric Meter Readings Titan Substation - 1986

$\begin{array}{lrrrrrr}\text { Month } & \text { kWh On-Peak } & & \text { kWh off-Peak } & \text { Total kWh } & \begin{array}{c}\text { Maximum } \\ \text { kW Demand }\end{array} & \text { Load Factor } \\ \text { JAN } & 453,380 & 1,573,820 & 2,027,200 & 3,454 & 76.4 \% \\ \text { FEB } & 511,555 & 1,577,245 & 2,088,800 & 3,652 & 82.2 \% \\ \text { MAR } & 470,440 & 1,433,560 & 1,904,000 & 3,629 & 75.4 \% \\ \text { APR } & 557,540 & 1,447,260 & 2,004,800 & 3,515 & 79.2 \% \\ \text { MAY } & 563,714 & 1,597,886 & 2,161,600 & 3,545 & 79.4 \% \\ \text { JUN } & 578,179 & 1,443,421 & 2,021,600 & 3,545 & 81.9 \% \\ \text { JUL } & 552,351 & 1,430,049 & 1,982,400 & 3,706 & 74.3 \% \\ \text { AUG } & 498,473 & 1,321,527 & 1,820,000 & 2,967 & 79.9 \% \\ \text { SEP } & 478,451 & 1,218,349 & 1,696,800 & 3,091 & 66.2 \% \\ \text { OCT } & 362,737 & 1,003,663 & 1,366,400 & 3,068 & 64.0 \% \\ \text { NOV } & 444,185 & 1,370,215 & 1,814,400 & 3,074 & 76.9 \% \\ \text { DEC } & 408,564 & 1,310,636 & 1,719,200 & 3,239 & 71.3 \% \\ \text { TOTALS } & 5,879,569 & 16,727,631 & 22,607,200 & & \end{array}$


IABLE 4.7. Florida Power \& Light Electric Meter Readings North Substation - 1987

\begin{tabular}{lrrrrrr} 
Month & kWh On-Peak & kWh 0ff-Peak & Total kWh & $\begin{array}{c}\text { Maximum } \\
\text { kW Demand }\end{array}$ & Load Factor \\
\cline { 7 - 7 } JAN & $1,233,167$ & $4,075,633$ & $5,308,800$ & 9,420 & $69.9 \%$ \\
FEB & 910,723 & $3,003,677$ & $3,914,400$ & 9,067 & $58.9 \%$ \\
MAR & $1,160,246$ & $3,476,554$ & $4,636,800$ & 9,717 & $67.3 \%$ \\
APR & $1,174,270$ & $2,857,730$ & $4,032,000$ & 8,376 & $68.7 \%$ \\
MAY & $1,292,722$ & $3,386,078$ & $4,678,800$ & 8,538 & $53.9 \%$ \\
JUN & $1,285,654$ & $2,939,546$ & $4,225,200$ & 8,437 & $72.0 \%$ \\
JUL & $1,264,531$ & $3,313,469$ & $4,578,000$ & 9,042 & $65.9 \%$ \\
AUG & $1,315,854$ & $2,976,546$ & $4,292,400$ & 8,286 & $71.9 \%$ \\
SEP & $1,429,598$ & $3,435,320$ & $4,864,918$ & 10,413 & $64.9 \%$ \\
OCT & $1,554,999$ & $3,955,401$ & $5,510,400$ & 10,362 & $71.5 \%$ \\
NOV & $1,355,299$ & $3,802,301$ & $5,157,600$ & 10,438 & $66.1 \%$ \\
DEC & $1,346,098$ & $4,260,702$ & $5,606,800$ & 9,999 & $75.0 \%$ \\
TOTALS & $15,323,161$ & $41,482,957$ & $56,806,118$ & &
\end{tabular}

IABLE 4.8. Florida Power \& Light Electric Meter Readings South Substation - 1987

\begin{tabular}{lrrrrrr} 
Month & kWh On-Peak & kWh 0ff-Peak & Total kWh & $\begin{array}{c}\text { Maximum } \\
\text { kW Demand }\end{array}$ & Load Factor \\
\cline { 7 - 7 } & & & & & \\
JAN & 857,623 & $2,922,377$ & $3,780,000$ & 7,106 & $69.3 \%$ \\
FEB & $1,167,676$ & $3,155,524$ & $4,323,200$ & 8,168 & $76.0 \%$ \\
MAR & 997,072 & $2,878,128$ & $3,875,200$ & 9,747 & $57.1 \%$ \\
APR & $1,082,920$ & $2,758,680$ & $3,841,600$ & 8,309 & $66.4 \%$ \\
MAY & $1,531,535$ & $4,107,665$ & $5,639,200$ & 10,644 & $66.9 \%$ \\
JUN & $1,590,034$ & $3,819,566$ & $5,409,600$ & 11,290 & $68.8 \%$ \\
JUL & $1,553,247$ & $4,192,353$ & $5,745,600$ & 10,490 & $71.3 \%$ \\
AUG & $1,735,268$ & $4,155,932$ & $5,891,200$ & 11,442 & $71.5 \%$ \\
SEP & $1,474,581$ & $3,867,819$ & $5,342,400$ & 10,611 & $69.9 \%$ \\
OCT & $1,096,480$ & $2,969,120$ & $4,065,600$ & 8,610 & $63.5 \%$ \\
NOV & 955,184 & $2,813,616$ & $3,768,807$ & 8,696 & $62.3 \%$ \\
DEC & 695,089 & $2,071,311$ & $2,766,400$ & 7,669 & $50.1 \%$ \\
TOTALS & $14,736,709$ & $39,712,091$ & $54,448,800$ & &
\end{tabular}


IABLE 4.9. Florida Power \& Light Electric Meter Readings

Titan Substation - 1987

Month kWh On-Peak kWh Off-Peak Iotal kWh MlW Demand Load Factor

$\begin{array}{lrrrrr}\text { JAN } & 391,079 & 1,356,121 & 1,747,200 & 3,071 & 74.1 \% \\ \text { FEB } & 413,036 & 1,266,964 & 1,680,000 & 3,068 & 78.7 \% \\ \text { MAR } & 404,431 & 1,253,169 & 1,657,600 & 3,195 & 74.5 \% \\ \text { APR } & 510,539 & 1,287,061 & 1,797,600 & 3,666 & 70.5 \% \\ \text { MAY } & 611,377 & 1,505,423 & 2,116,800 & 3,888 & 68.7 \% \\ \text { JUN } & 595,914 & 1,442,486 & 2,038,400 & 3,798 & 77.1 \% \\ \text { JUL } & 600,267 & 1,650,933 & 2,251,200 & 4,066 & 72.1 \% \\ \text { AUG } & 699,307 & 1,663,893 & 2,363,200 & 4,477 & 73.3 \% \\ \text { SEP } & 711,175 & 1,848,025 & 2,559,200 & 4,422 & 80.4 \% \\ \text { OCT } & 681,666 & 1,883,134 & 2,564,800 & 4,331 & 79.6 \% \\ \text { NOV } & 603,141 & 1,760,059 & 2,363,200 & 4,250 & 79.9 \% \\ \text { DEC } & 452,787 & 1,400,813 & 1,853,600 & 3,970 & 64.8 \% \\ \text { TOTALS } & 6,674,719 & 18,318,081 & 24,992,800 & & \end{array}$

IABLE 4.10. Florida Power \& Light Electric Meter Readings North Substation - 1988

\begin{tabular}{lrrrrrr} 
Month & kWh On-Peak & kWh 0ff-Peak & Total kWh & $\begin{array}{c}\text { Maximum } \\
\text { kW Demand }\end{array}$ & Load Factor \\
\cline { 5 - 6 } JAN & $1,253,161$ & $4,400,039$ & $5,653,200$ & 11,390 & $62.7 \%$ \\
FEB & $1,344,929$ & $3,955,471$ & $5,300,400$ & 10,413 & $70.7 \%$ \\
MAR & $1,133,940$ & $3,385,260$ & $4,519,200$ & 9,808 & $66.2 \%$ \\
APR & $1,376,054$ & $3,764,746$ & $5,140,800$ & 9,117 & $73.4 \%$ \\
MAY & $1,406,001$ & $3,121,599$ & $4,527,600$ & 10,181 & $63.9 \%$ \\
JUN & $1,552,716$ & $3,646,884$ & $5,199,600$ & 10,367 & $69.7 \%$ \\
JUL & $1,644,166$ & $4,277,834$ & $5,922,000$ & 11,098 & $69.5 \%$ \\
AUG & $1,766,092$ & $4,038,308$ & $5,804,400$ & 13,270 & $62.8 \%$ \\
SEP & $1,892,575$ & $4,827,425$ & $6,720,000$ & 11,516 & $73.7 \%$ \\
OCT & $1,734,647$ & $3,893,353$ & $5,628,000$ & 11,269 & $69.4 \%$ \\
NOV & $1,373,032$ & $4,103,768$ & $5,476,800$ & 11,128 & $68.4 \%$ \\
DEC & $1,232,965$ & $4,125,192$ & $5,358,157$ & 10,292 & $67.8 \%$ \\
TOTALS & $17,710,278$ & $47,539,879$ & $65,250,157$ & &
\end{tabular}


IABLE 4.11. Florida Power \& Light Electric Meter Readings South Substation - 1988

$\begin{array}{lrrrrrr}\text { Month } & \text { kWh On-Peak } & \text { kWh Off-Peak } & \text { Total kwh } & \begin{array}{c}\text { Maximum } \\$\cline { 6 - 7 } \text {$kWemand }\end{array} & \text { Load Factor } \\ \text { JAN } & 845,048 & 2,890,152 & 3,735,200 & 7,458 & 63.2 \% \\ \text { FEB } & 833,980 & 2,498,020 & 3,332,000 & 6,707 & 69.0 \% \\ \text { MAR } & 778,343 & 2,318,457 & 3,096,800 & 6,881 & 64.7 \% \\ \text { APR } & 1,167,367 & 3,060,633 & 4,228,000 & 8,585 & 64.1 \% \\ \text { MAY } & 1,252,427 & 3,070,773 & 4,323,200 & 8,556 & 72.6 \% \\ \text { JUN } & 1,176,610 & 2,939,390 & 4,116,000 & 8,410 & 68.0 \% \\ \text { JUL } & 1,091,064 & 3,047,336 & 4,138,400 & 8,240 & 65.4 \% \\ \text { AUG } & 1,134,618 & 2,701,382 & 3,836,000 & 9,082 & 60.7 \% \\ \text { SEP } & 1,197,232 & 3,226,768 & 4,424,000 & 8,707 & 64.2 \% \\ \text { OCT } & 1,094,647 & 2,534,153 & 3,628,800 & 6,861 & 73.5 \% \\ \text { NOV } & 881,751 & 2,657,449 & 3,539,200 & 6,752 & 72.8 \% \\ \text { DEC } & 911,565 & 3,031,684 & 3,943,249 & 6,799 & 75.5 \% \\ \text { TOTALS } & 12,364,652 & 33,976,197 & 46,340,849 & & \end{array}$

IABLE 4.12. Florida Power \& Light Electric Meter Readings Titan Substation - 1988

$\begin{array}{lrrrrrr}\text { Month } & \text { kWh On-Peak } & \text { kWh 0ff-Peak } & \text { Total kWh } & \begin{array}{c}\text { Maximum } \\ \text { kW Demand }\end{array} & \text { Load Factor } \\ & & & & & & \\ \text { JAN } & 308,113 & 1,394,287 & 1,702,400 & 4,197 & 51.2 \% \\ \text { FEB } & 573,773 & 1,733,427 & 2,307,200 & 5,361 & 59.8 \% \\ \text { MAR } & 816,256 & 2,414,944 & 3,231,200 & 6,271 & 74.0 \% \\ \text { APR } & 1,086,630 & 2,995,770 & 4,082,400 & 6,938 & 76.6 \% \\ \text { MAY } & 897,060 & 2,334,140 & 3,231,200 & 7,115 & 65.2 \% \\ \text { JUN } & 996,206 & 2,856,594 & 3,852,800 & 6,769 & 79.1 \% \\ \text { JUL } & 1,178,337 & 3,374,463 & 4,552,800 & 6,955 & 85.2 \% \\ \text { AUG } & 1,146,717 & 2,997,283 & 4,144,000 & 6,954 & 85.6 \% \\ \text { SEP } & 1,104,130 & 3,140,670 & 4,244,800 & 6,834 & 78.4 \% \\ \text { OCT } & 935,784 & 2,289,816 & 3,225,600 & 5,366 & 83.5 \% \\ \text { NOV } & 804,383 & 2,510,817 & 3,315,200 & 5,771 & 79.8 \% \\ \text { DEC } & 811,147 & 2,872,402 & 3,683,549 & 5,939 & 80.8 \% \\ \text { TOTALS } & 10,658,536 & 30,914,613 & 41,573,149 & & \end{array}$


IABLE 4.13. Florida Power \& Light Electric Meter Readings North Substation - 1989

$\begin{array}{lrrrrrr}\text { Month } & \text { kWh On-Peak } & \text { kWh Off-Peak } & \text { Total klh } & \begin{array}{c}\text { Maximum } \\ \text { kW Demand }\end{array} & \text { Load Factor } \\ \text { JAN } & 1,173,897 & 3,630,903 & 4,804,800 & 11,043 & 58.5 \% \\ \text { FEB } & 1,332,609 & 3,925,791 & 5,258,400 & 10,307 & 70.9 \% \\ \text { MAR } & 1,303,609 & 4,223,591 & 5,527,200 & 10,196 & 75.3 \% \\ \text { APR } & 1,451,112 & 3,555,288 & 5,006,400 & 11,219 & 64.1 \% \\ \text { MAY } & 1,844,809 & 4,261,991 & 6,106,800 & 11,874 & 73.9 \% \\ \text { JUN } & 2,182,443 & 5,755,557 & 7,938,000 & 13,497 & 76.6 \% \\ \text { JUL } & 2,646,131 & 6,434,269 & 9,080,400 & 17,005 & 74.2 \% \\ \text { AUG } & 2,776,987 & 6,437,813 & 9,214,800 & 16,561 & 77.3 \% \\ \text { SEP } & 2,608,777 & 6,807,623 & 9,416,400 & 16,692 & 73.5 \% \\ \text { OCT } & 2,615,218 & 6,011,582 & 8,626,800 & 15,947 & 75.1 \% \\ \text { NOV } & 1,912,415 & 6,117,985 & 8,030,400 & 14,636 & 71.4 \% \\ \text { DEC } & 1,772,036 & 5,467,138 & 7,239,174 & 14,465 & 69.5 \% \\ \text { TOTALS } & 23,620,043 & 62,629,531 & 86,249,574 & & \end{array}$

IABLE 4.14. Florida Power \& Light Electric Meter Readings South Substation - 1989

\begin{tabular}{lrrrrrr} 
Month & kWh On-Peak & kWh 0ff-Peak & Total kWh & $\begin{array}{c}\text { Maximum } \\
\text { kWlidemand }\end{array}$ & Load Factor \\
\cline { 7 - 7 } JAN & $1,093,284$ & $3,453,916$ & $4,547,200$ & 9,492 & $66.5 \%$ \\
FEB & $1,202,743$ & $3,478,857$ & $4,681,600$ & 9,374 & $69.4 \%$ \\
MAR & $1,079,676$ & $3,607,524$ & $4,687,200$ & 9,732 & $64.7 \%$ \\
APR & $1,313,445$ & $3,233,755$ & $4,547,200$ & 7,757 & $84.2 \%$ \\
MAY & $1,261,281$ & $3,196,319$ & $4,457,600$ & 9,348 & $68.5 \%$ \\
JUN & $1,281,552$ & $3,573,648$ & $4,855,200$ & 9,322 & $67.8 \%$ \\
JUL & $1,234,372$ & $3,211,228$ & $4,445,600$ & 9,421 & $65.5 \%$ \\
AUG & $1,247,975$ & $3,064,025$ & $4,312,000$ & 9,882 & $60.6 \%$ \\
SEP & $1,180,218$ & $3,394,982$ & $4,575,200$ & 9,383 & $63.5 \%$ \\
OCT & $1,098,902$ & $2,759,498$ & $3,858,400$ & 9,796 & $54.7 \%$ \\
NOV & $1,035,050$ & $3,439,350$ & $4,474,400$ & 8,415 & $69.2 \%$ \\
DEC & 902,556 & $2,972,644$ & $3,875,200$ & 7,822 & $68.8 \%$ \\
TOTALS & $13,931,054$ & $39,385,746$ & $53,316,800$ & &
\end{tabular}


TABLE 4.15. Florida Power \& Light Electric Meter Readings Titan Substation - 1989

\begin{tabular}{lrrrrr} 
Month & kWh On-Peak & kWh 0ff-Peak & Total klih & $\begin{array}{c}\text { Maximum } \\
\text { kW Demand }\end{array}$ & Load Factor \\
\cline { 1 - 1 } JAN & 714,911 & $2,359,489$ & $3,074,400$ & 5,515 & $77.4 \%$ \\
FEB & 925,127 & $2,770,873$ & $3,696,000$ & 5,964 & $86.1 \%$ \\
MAR & 828,209 & $2,834,191$ & $3,662,400$ & 6,539 & $75.3 \%$ \\
APR & 949,372 & $2,517,028$ & $3,466,400$ & 5,957 & $83.6 \%$ \\
MAY & 901,724 & $2,346,276$ & $3,248,000$ & 5,919 & $78.8 \%$ \\
JUN & 735,571 & $2,109,229$ & $2,844,800$ & 5,440 & $68.1 \%$ \\
JUL & 490,699 & $1,329,301$ & $1,820,000$ & 3,932 & $64.3 \%$ \\
AUG & 573,526 & $1,442,474$ & $2,016,000$ & 4,081 & $68.6 \%$ \\
SEP & 448,745 & $1,315,255$ & $1,764,000$ & 3,256 & $70.5 \%$ \\
OCT & 406,019 & $1,044,381$ & $1,450,400$ & 2,671 & $75.4 \%$ \\
NOV & 397,277 & $1,349,923$ & $1,747,200$ & 3,053 & $74.5 \%$ \\
DEC & 447,863 & $1,467,074$ & $1,914,937$ & 3,318 & $80.2 \%$ \\
TOTALS & $7,819,043$ & $22,885,494$ & $30,704,537$ & &
\end{tabular}

TABLE 4.16. Florida Power \& Light Electric Meter Readings North Substation - 1990

$\begin{array}{lrrrrrr}\text { Month } & \text { kWh On-Peak } & \text { kWh Off-Peak } & \text { Total kWh } & \begin{array}{c}\text { Maximum } \\ \text { kW Demand }\end{array} & \text { Load Factor } \\ \text { JAN } & 1,732,288 & 5,382,512 & 7,114,800 & 13,800 & 62.4 \% \\ \text { FEB } & 1,469,460 & 4,780,140 & 6,249,600 & 13,457 & 62.4 \% \\ \text { MAR } & 1,416,862 & 4,253,138 & 5,670,000 & 11,678 & 69.8 \% \\ \text { APR } & 1,771,416 & 4,259,784 & 6,031,200 & 12,071 & 71.8 \% \\ \text { MAY } & 2,123,922 & 4,764,078 & 6,888,000 & 13,759 & 69.5 \% \\ \text { JUN } & 2,247,870 & 5,866,530 & 8,114,400 & 14,747 & 71.6 \% \\ \text { JUL } & 2,254,332 & 5,515,668 & 7,770,000 & 13,981 & 77.2 \% \\ \text { AUG } & 2,442,293 & 6,050,107 & 8,492,400 & 14,823 & 74.6 \% \\ \text { SEP } & 2,242,757 & 5,577,643 & 7,820,400 & 14,858 & 75.6 \% \\ \text { OCT } & 2,410,277 & 5,519,323 & 7,929,600 & 14,445 & 76.2 \% \\ \text { NOV } & 1,739,755 & 5,394,680 & 7,134,435 & 13,028 & 69.1 \% \\ \text { DEC } & 1,543,975 & 4,755,696 & 6,299,671 & 13,124 & 66.7 \% \\ \text { TOTALS } & 23,395,207 & 62,119,299 & 85,514,506 & & \end{array}$


JABLE 4.17. Florida Power \& Light Electric Meter Readings South Substation - 1990

\begin{tabular}{lrrrrrr} 
Month & kWh On-Peak & kWh 0ff-Peak & Total kWh & $\begin{array}{c}\text { Maximum } \\
\text { kW Demand }\end{array}$ & Load Factor \\
\cline { 7 - 7 } JAN & 884,267 & $2,649,333$ & $3,533,600$ & 7,194 & $68.2 \%$ \\
FEB & $1,183,437$ & $3,862,163$ & $5,045,600$ & 9,781 & $69.3 \%$ \\
MAR & 987,220 & $2,949,580$ & $3,936,800$ & 9,156 & $61.8 \%$ \\
APR & $1,056,396$ & $2,785,204$ & $3,841,600$ & 7,368 & $74.9 \%$ \\
MAY & $1,295,944$ & $3,133,656$ & $4,429,600$ & 9,505 & $64.7 \%$ \\
JUN & $1,183,285$ & $3,660,715$ & $4,844,000$ & 10,004 & $63.0 \%$ \\
JUL & $1,318,956$ & $3,631,444$ & $4,950,400$ & 9,497 & $72.4 \%$ \\
AUG & $1,201,330$ & $3,284,270$ & $4,485,600$ & 8,285 & $70.5 \%$ \\
SEP & $1,164,422$ & $3,147,578$ & $4,312,000$ & 8,706 & $71.2 \%$ \\
OCT & $1,154,893$ & $2,776,307$ & $3,931,200$ & 6,999 & $78.0 \%$ \\
NOV & $1,230,135$ & $4,006,286$ & $5,236,421$ & 8,612 & $76.8 \%$ \\
DEC & 896,771 & $2,810,429$ & $3,707,200$ & 8,420 & $61.2 \%$ \\
TOTALS & $13,557,056$ & $38,696,965$ & $52,254,021$ & &
\end{tabular}

IABLE 4.18. Florida Power \& Light Electric Meter Readings Titan Substation - 1990

\begin{tabular}{lrrrrrr} 
Month & kWh On-Peak & kWh off-Peak & Total kWh & $\begin{array}{c}\text { Maximum } \\
\text { kW Demand }\end{array}$ & Load Factor \\
\cline { 7 - 7 } JAN & 342,596 & $1,096,604$ & $1,439,200$ & 3,002 & $66.6 \%$ \\
FEB & 649,965 & $2,105,235$ & $2,755,200$ & 3,307 & $69.8 \%$ \\
MAR & 766,159 & $2,280,241$ & $3,046,400$ & 5,653 & $77.4 \%$ \\
APR & 980,604 & $2,569,796$ & $3,550,400$ & 6,527 & $78.2 \%$ \\
MAY & $1,098,402$ & $2,715,198$ & $3,813,600$ & 6,594 & $80.3 \%$ \\
JUN & $1,103,661$ & $3,146,739$ & $4,250,400$ & 7,085 & $78.1 \%$ \\
JUL & 916,586 & $2,353,814$ & $3,270,400$ & 6,206 & $73.2 \%$ \\
AUG & $1,135,446$ & $3,030,954$ & $4,166,400$ & 6,276 & $86.4 \%$ \\
SEP & $1,061,012$ & $2,858,988$ & $3,920,000$ & 6,399 & $88.0 \%$ \\
OCT & $1,139,211$ & $2,803,189$ & $3,942,400$ & 6,307 & $86.8 \%$ \\
NOV & 801,898 & $2,586,102$ & $3,388,000$ & 5,751 & $74.4 \%$ \\
DEC & 604,089 & $1,904,711$ & $2,508,800$ & 4,806 & $72.5 \%$ \\
TOTALS & $10,599,629$ & $29,451,571$ & $40,051,200$ & &
\end{tabular}


IABLE 4.19. Florida Power \& Light Electric Meter Readings North Substation - 1991

\begin{tabular}{|c|c|c|c|c|c|}
\hline Month & kwh On-Peak & kWh off-Peak & Total kWh & $\begin{array}{c}\text { Maximum } \\
\text { kW Demand }\end{array}$ & Load Factor \\
\hline JAN & $1,144,397$ & $4,063,603$ & $5,208,000$ & 12,560 & $54.0 \%$ \\
\hline FEB & $1,827,098$ & $5,464,102$ & $7,291,200$ & 12,257 & $85.5 \%$ \\
\hline MAR & $1,787,228$ & $5,007,908$ & $6,795,136$ & 13,185 & $74.0 \%$ \\
\hline APR & $2,014,581$ & $4,814,619$ & $6,829,200$ & 13,366 & $73.4 \%$ \\
\hline MAY & $2,203,037$ & $5,037,763$ & $7,240,800$ & 14,036 & $74.1 \%$ \\
\hline JUN & $2,325,632$ & $6,410,368$ & $8,736,000$ & 15,422 & $73.8 \%$ \\
\hline JUL & $2,402,878$ & $5,854,322$ & $8,257,200$ & 15,397 & $74.5 \%$ \\
\hline AUG & $2,562,761$ & $6,457,752$ & $9,020,513$ & 16,622 & $70.7 \%$ \\
\hline SEP & $2,428,957$ & $5,912,243$ & $8,341,200$ & 16,365 & $70.8 \%$ \\
\hline OCT & $2,302,634$ & $5,265,627$ & $7,568,261$ & 14,545 & $72.3 \%$ \\
\hline NOV & $1,809,181$ & $5,372,819$ & $7,182,000$ & 14,152 & $66.1 \%$ \\
\hline DEC & $1,635,067$ & $5,278,133$ & $6,913,200$ & 13,706 & $65.7 \%$ \\
\hline TOTALS & $24,443,451$ & $64,939,259$ & $89,382,710$ & & \\
\hline
\end{tabular}

IABLE 4.20. Florida Power \& Light Electric Meter Readings South Substation - 1991

$\begin{array}{lrrrrrr}\text { Month } & \text { kWh On-Peak } & \text { kWh 0ff-Peak } & \text { Total kWh } & \begin{array}{c}\text { Maximum } \\ \text { kW Demand }\end{array} & \text { Load Factor } \\ \text { JAN } & 1,377,885 & 4,457,315 & 5,835,200 & 8,492 & 89.5 \% \\ \text { FEB } & 968,724 & 2,912,076 & 3,880,800 & 9,153 & 60.9 \% \\ \text { MAR } & 960,092 & 3,290,308 & 4,250,400 & 9,326 & 65.5 \% \\ \text { APR } & 1,203,171 & 3,052,829 & 4,256,000 & 9,216 & 66.4 \% \\ \text { MAY } & 1,183,502 & 2,870,898 & 4,054,400 & 7,894 & 73.8 \% \\ \text { JUN } & 1,304,358 & 3,741,242 & 5,045,600 & 8,731 & 75.2 \% \\ \text { JUL } & 1,393,592 & 3,719,208 & 5,112,800 & 9,537 & 74.5 \% \\ \text { AUG } & 1,500,854 & 4,183,146 & 5,684,000 & 9,820 & 75.4 \% \\ \text { SEP } & 1,292,652 & 3,372,148 & 4,664,800 & 8,872 & 73.0 \% \\ \text { OCT } & 1,294,292 & 3,133,696 & 4,427,988 & 10,369 & 59.3 \% \\ \text { NOV } & 1,335,986 & 4,079,214 & 5,415,200 & 9,885 & 71.3 \% \\ \text { DEC } & 969,358 & 3,180,242 & 4,149,600 & 8,227 & 65.7 \% \\ \text { TOTALS } & 14,784,466 & 41,992,322 & 56,776,788 & & \end{array}$


IABLE 4.21. Florida Power \& Light Electric Meter Readings

Titan Substation - 1991

\begin{tabular}{|c|c|c|c|c|c|}
\hline Month & KWh On-Peak & kWh off-Peak & Total kWh & $\begin{array}{c}\text { Maximum } \\
\text { kW Demand }\end{array}$ & Load Factor \\
\hline JAN & 656,509 & $2,115,491$ & $2,772,000$ & 5,611 & $64.3 \%$ \\
\hline FEB & 578,385 & $2,830,788$ & $3,409,173$ & 6,184 & $79.2 \%$ \\
\hline MAR & 899,045 & $2,757,755$ & $3,656,800$ & 6,234 & $84.3 \%$ \\
\hline APR & 962,039 & $2,476,361$ & $3,438,400$ & 6,137 & $80.5 \%$ \\
\hline MAY & $1,086,120$ & $2,710,680$ & $3,796,800$ & 6,838 & $79.8 \%$ \\
\hline JUN & $1,053,928$ & $2,611,968$ & $3,665,896$ & 6,774 & $70.5 \%$ \\
\hline JUL & $1,107,544$ & $2,863,003$ & $3,970,547$ & 6,807 & $81.0 \%$ \\
\hline AUG & $1,131,438$ & $3,022,315$ & $4,153,753$ & 6,653 & $81.3 \%$ \\
\hline SEP & $1,260,285$ & $3,302,386$ & $4,562,671$ & 7,444 & $85.1 \%$ \\
\hline OCT & $1,249,666$ & $3,011,934$ & $4,261,600$ & 7,523 & $78.7 \%$ \\
\hline NOV & $1,057,418$ & $3,254,582$ & $4,312,000$ & 7,195 & $78.0 \%$ \\
\hline DEC & 937,209 & $2,977,191$ & $3,914,400$ & 7,600 & $67.1 \%$ \\
\hline TOTALS & $11,979,586$ & $33,934,454$ & $45,914,040$ & & \\
\hline
\end{tabular}


IABLE 4.22. Cape Canaveral AFS Electric Energy-Use Breakdown

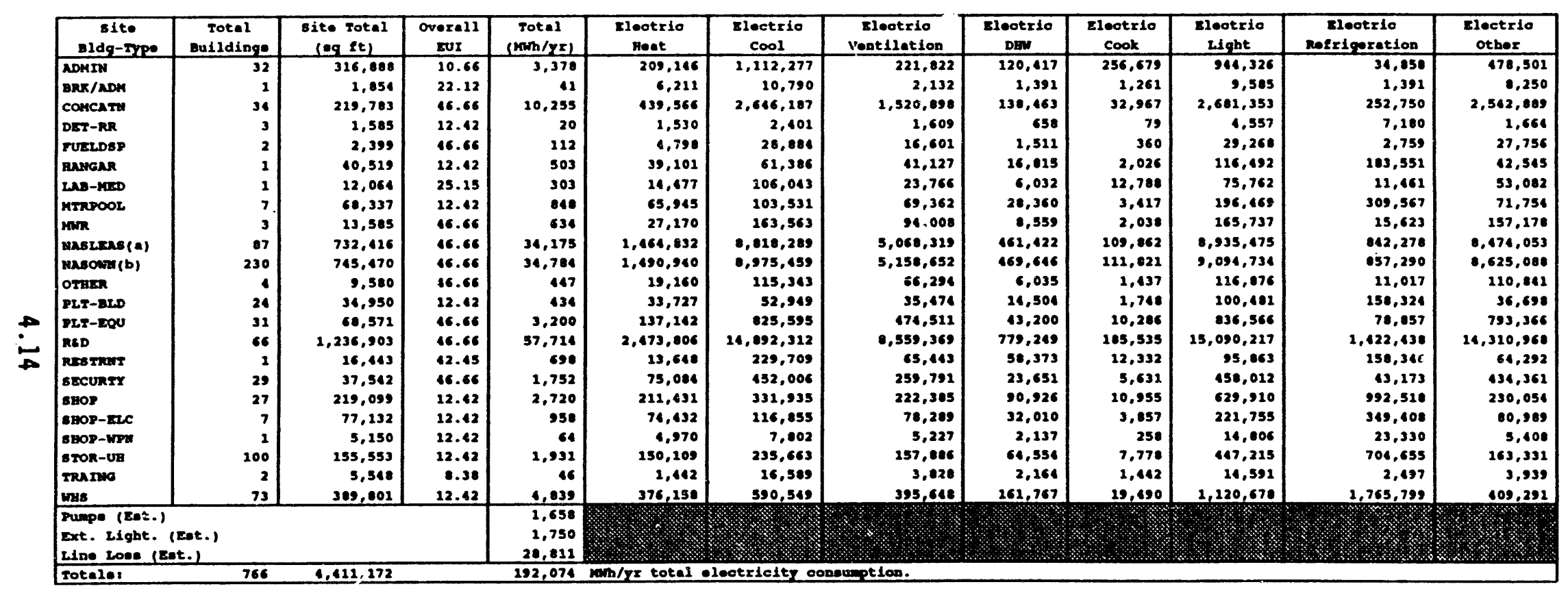

(a) mask loeeod bulldioge

(b) Mask oumed bulldinge

all unite are kmb/yx unlees otberwiee noted. 


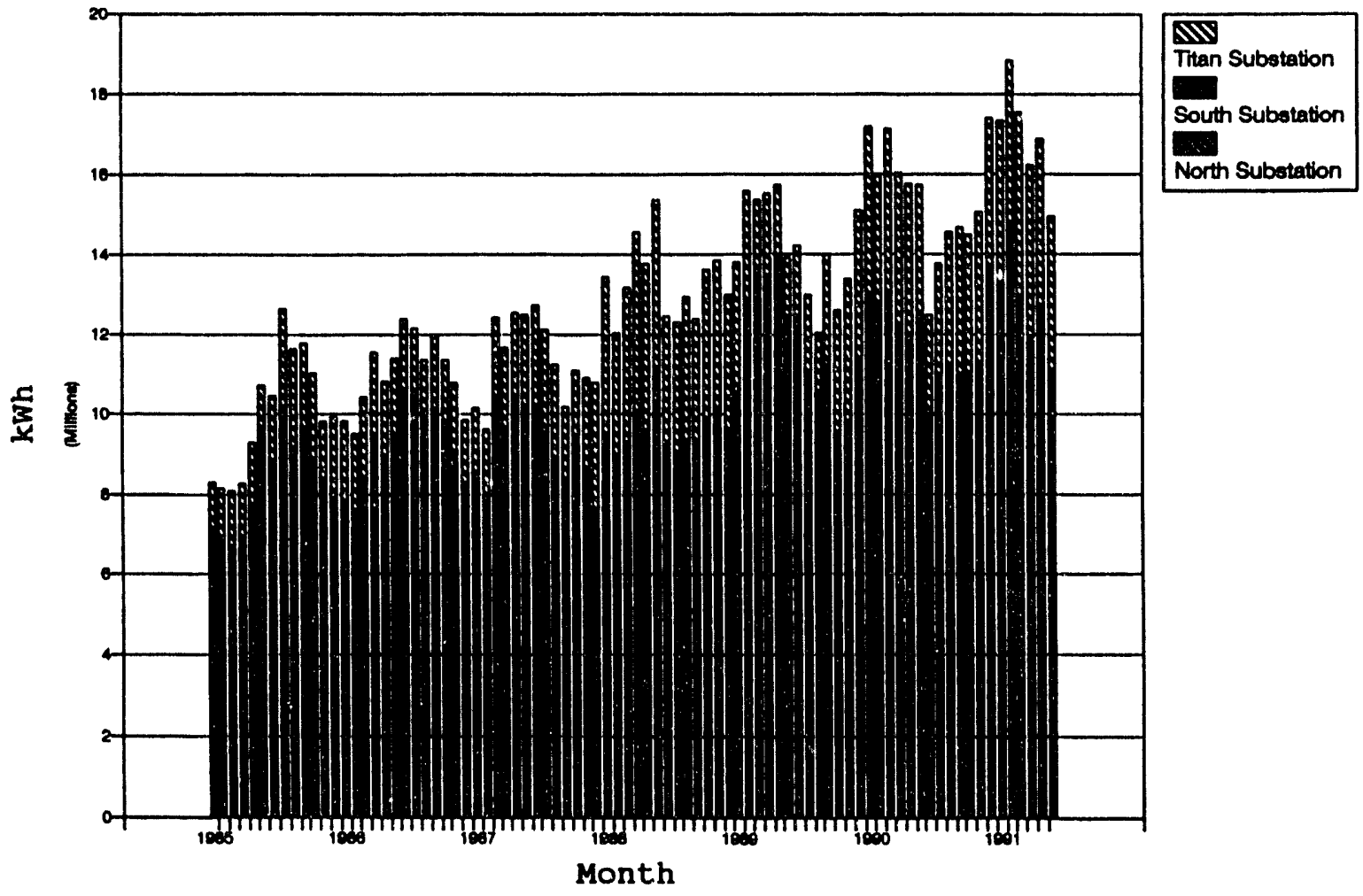

FIGURE 4.1. Cape Canaveral AFS Electrical Consumption, January 1985 to December 1991

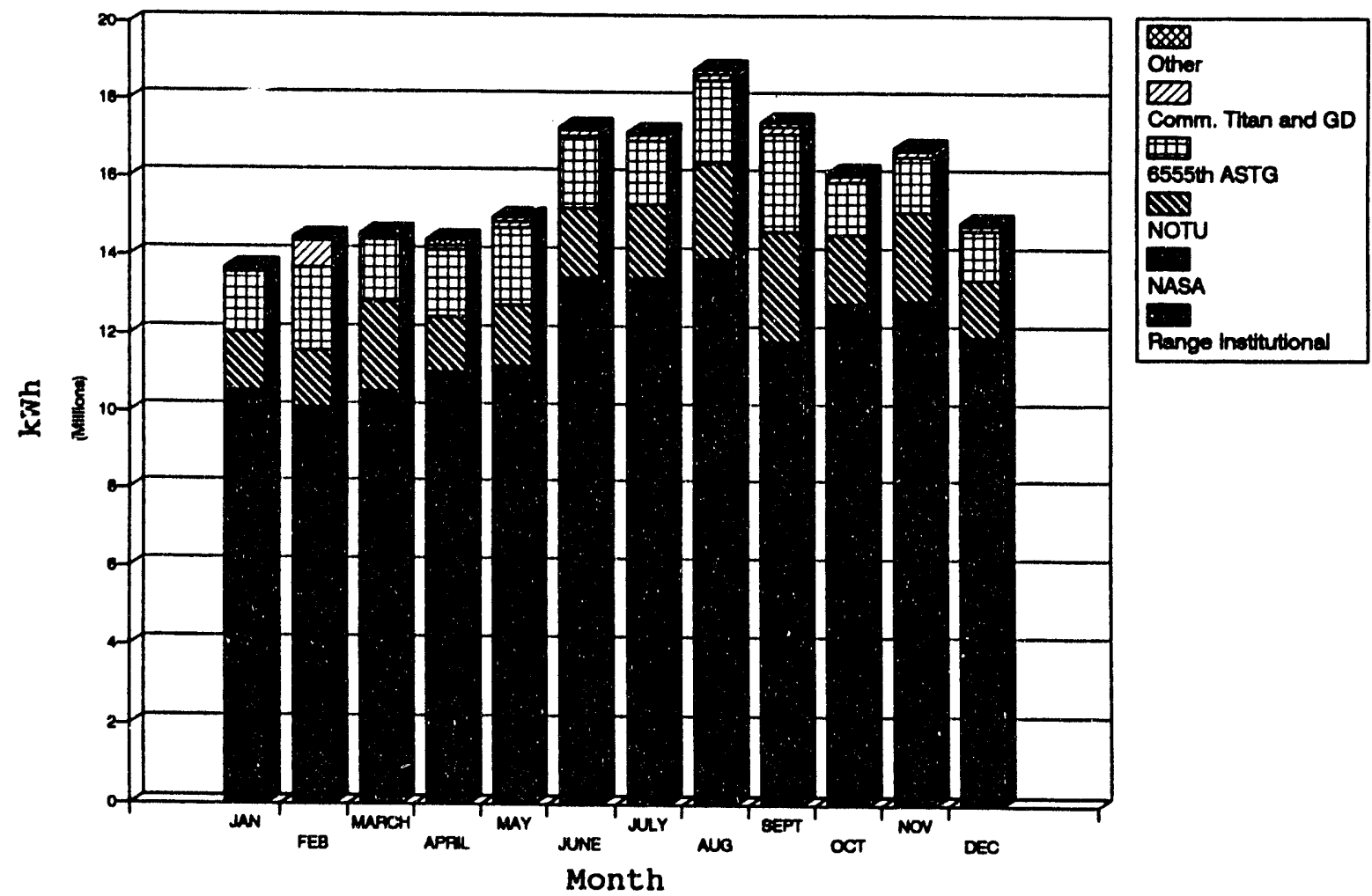

FIGURE 4.2. Cape Canaveral AFS End User Electrical Consumption, 1991 


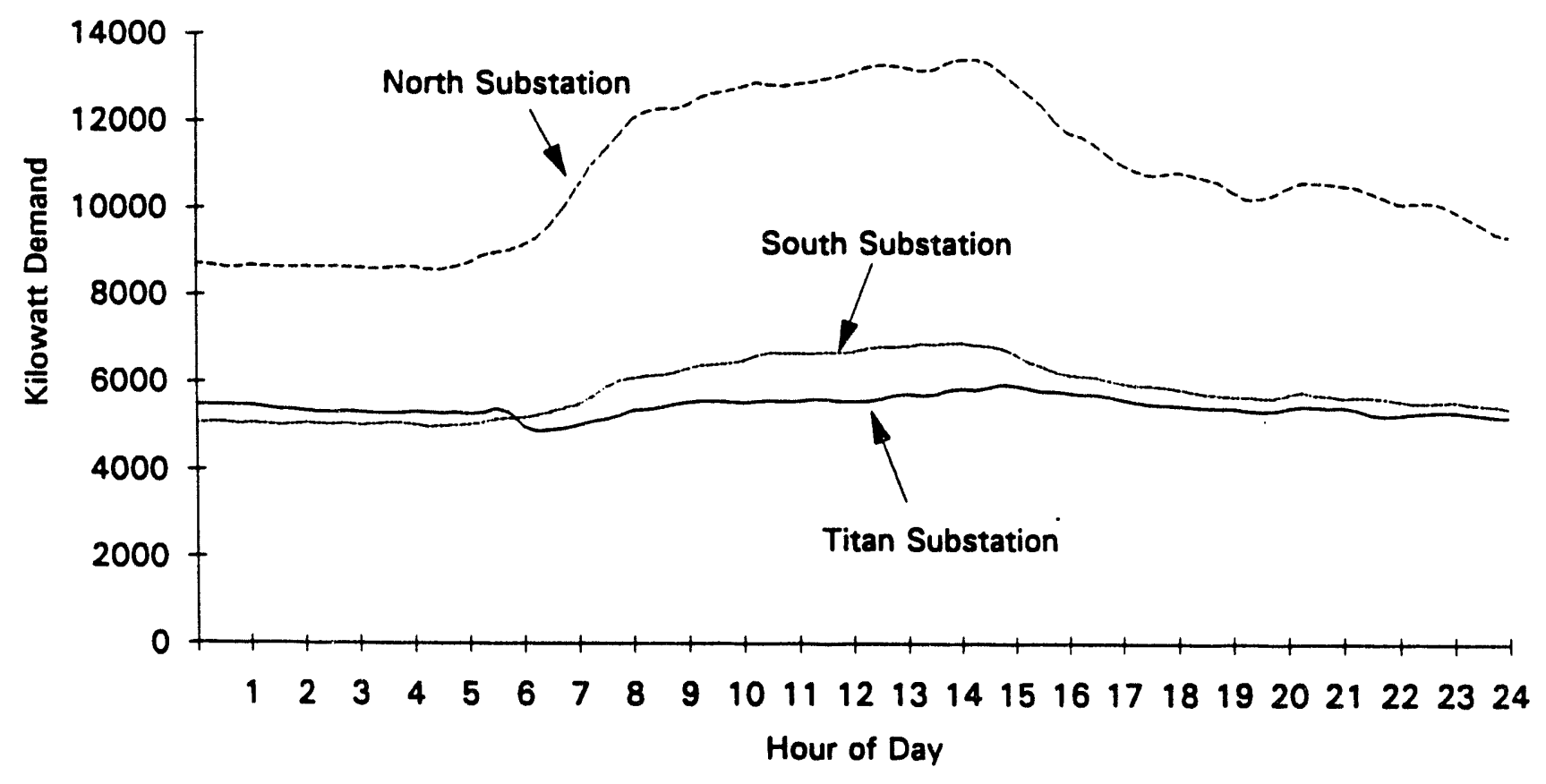

FIGURE 4.3. Load Profile at Cape Canaveral AFS - Spring Weekday (1991)

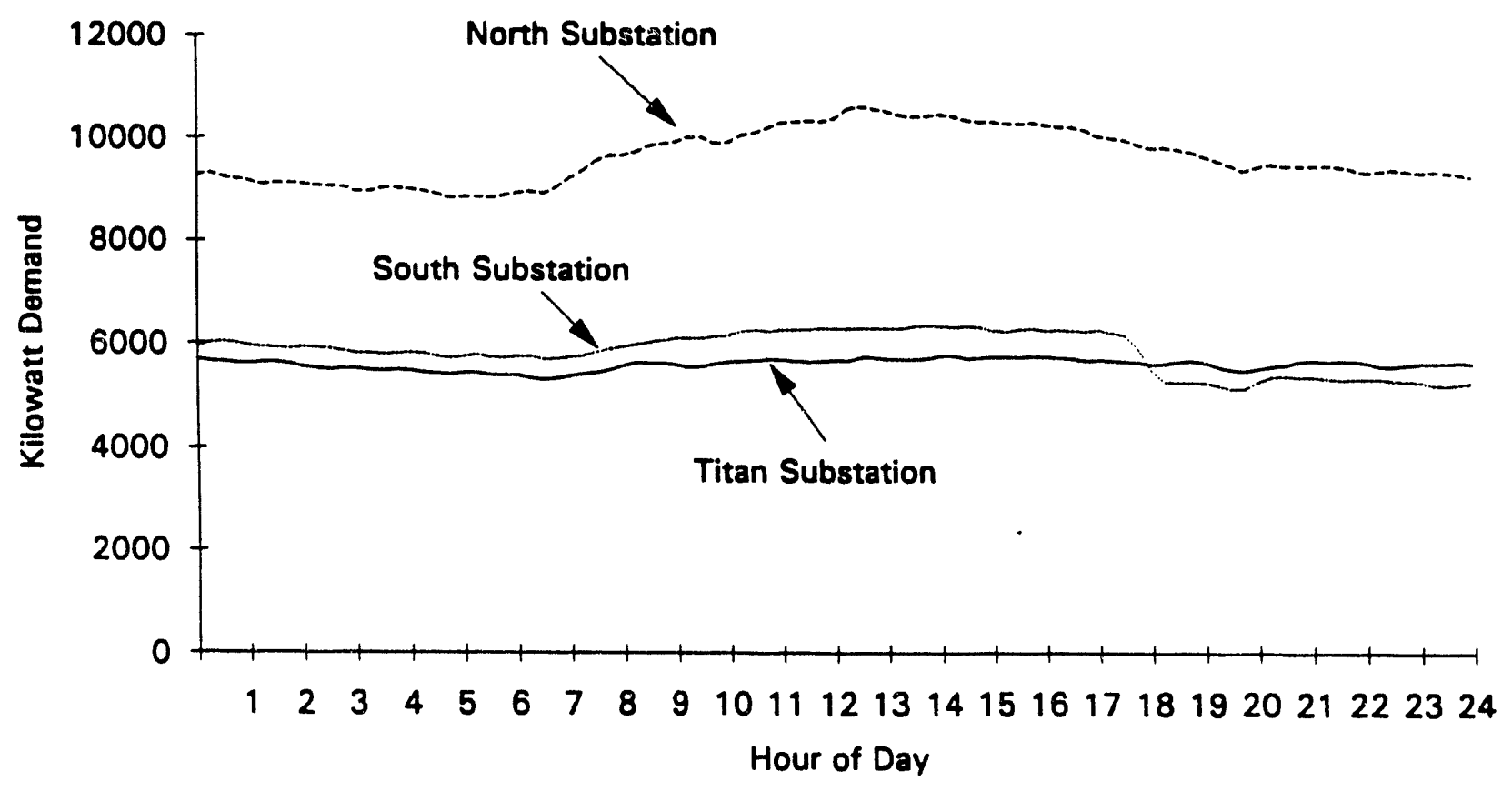

FIGURE 4.4. Load Profile at Cape Canaveral AFS - Spring Weekend (1991) 


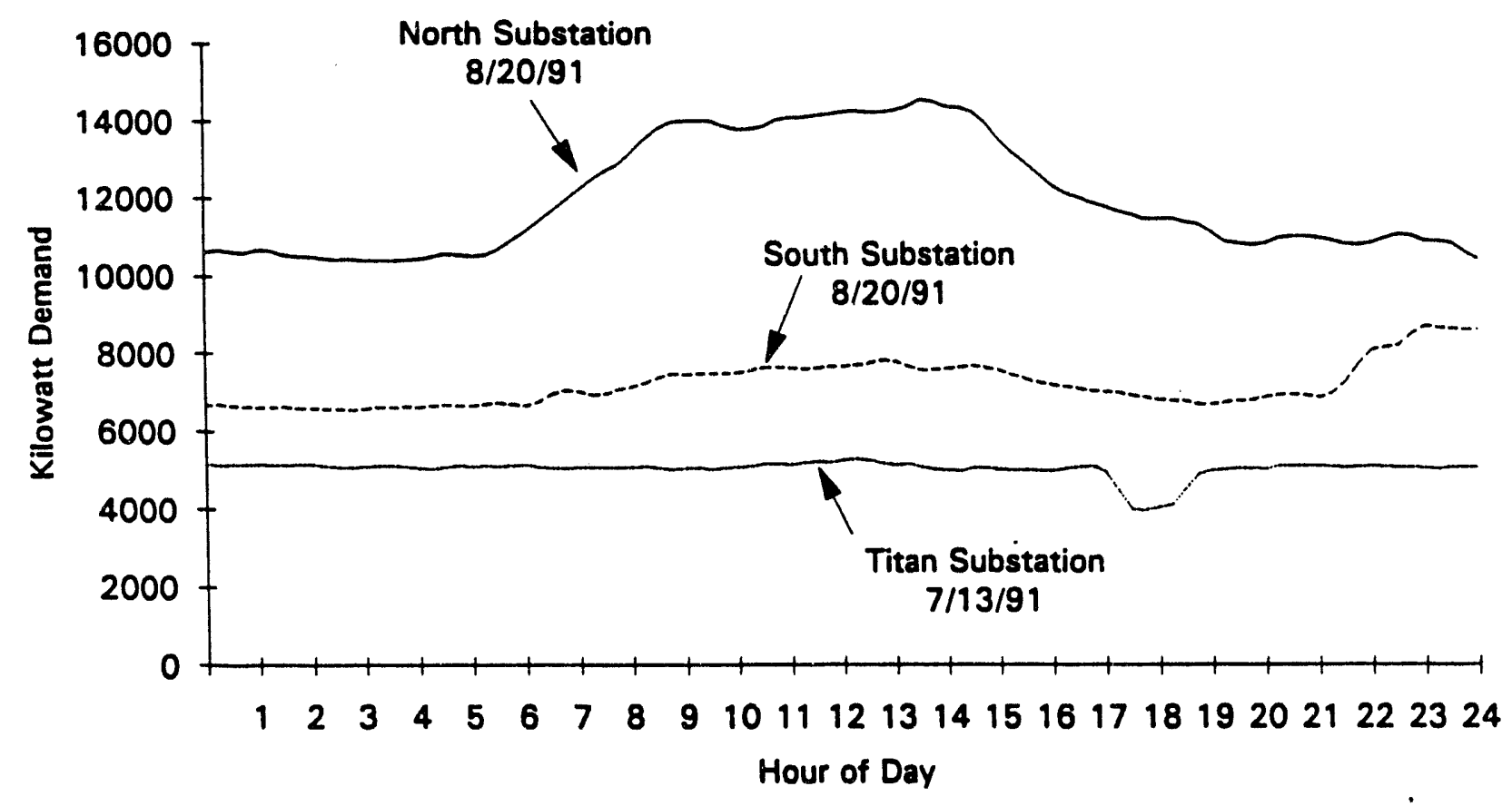

FIGURE 4.5. Load Profile at Cape Canaveral AFS - Summer Weekday (1991)

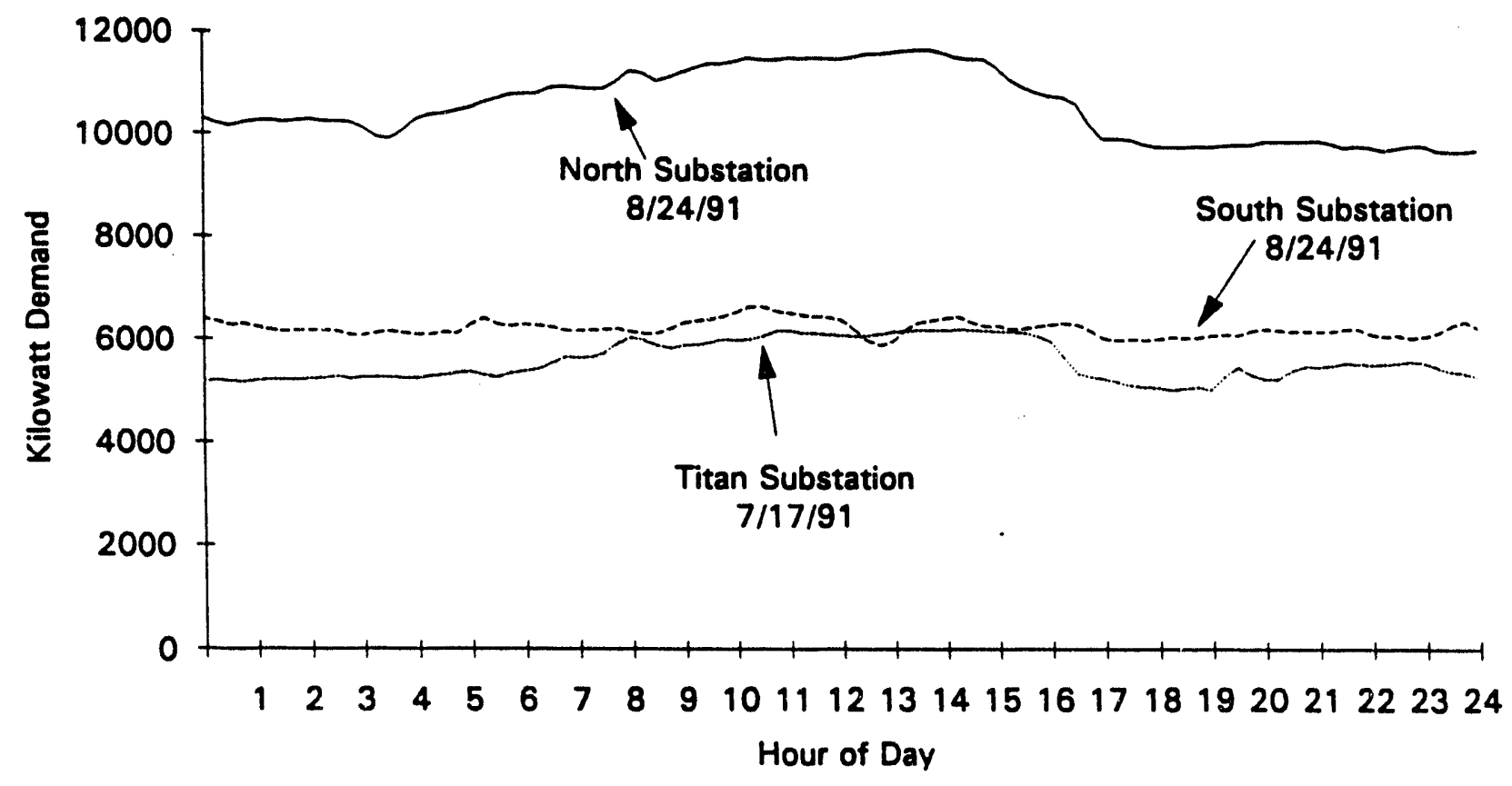

FIGURE 4.6. Load Profile at Cape Canaveral AFS - Summer Weekend (1991) 


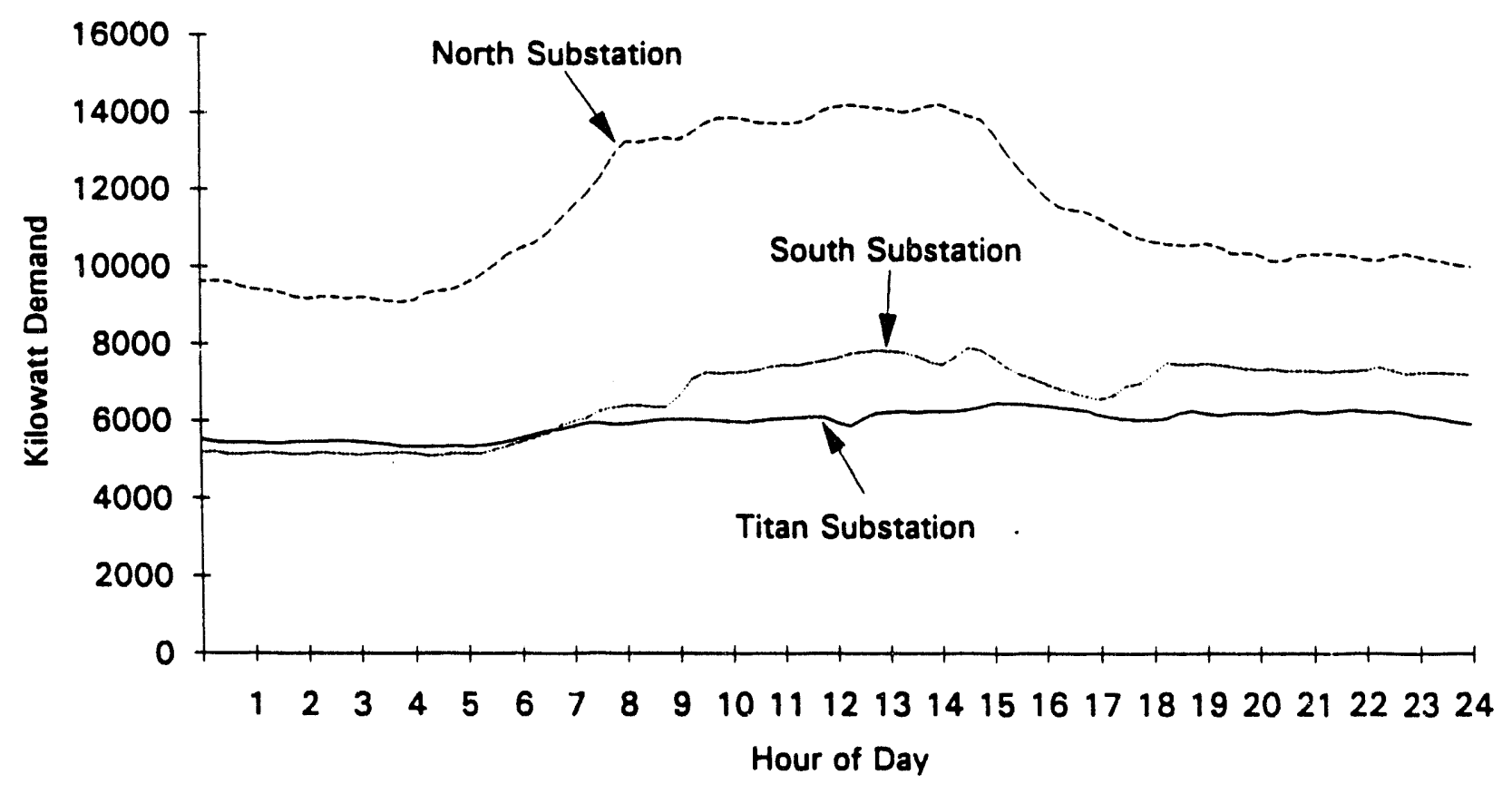

FIGURE 4.7. Load Profile at Cape Canaveral AFS - Fall Weekday (1991)

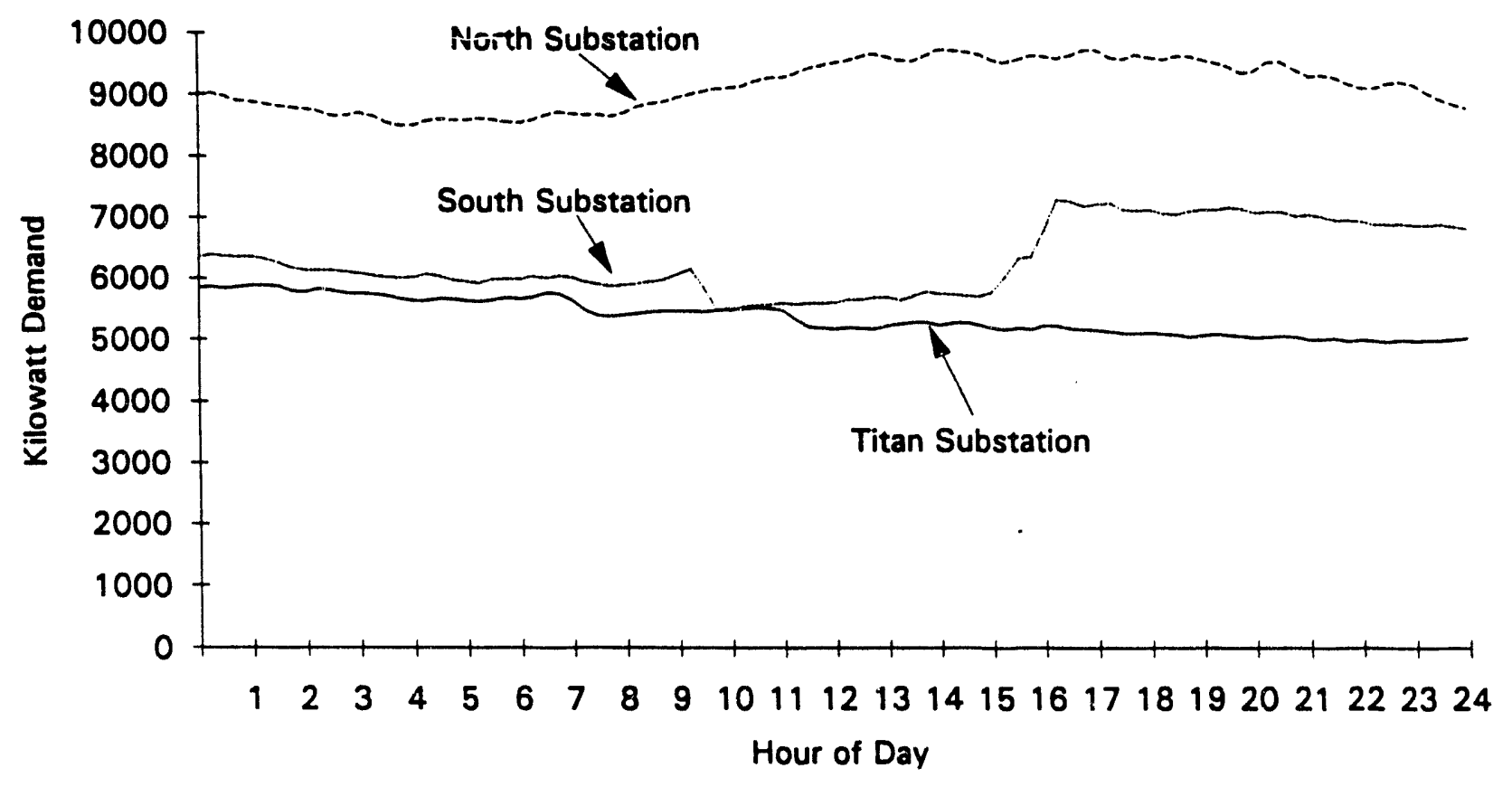

EIGURE 4.8. Load Profile at Cape Canaveral AFS - Fall Weekend (1991) 


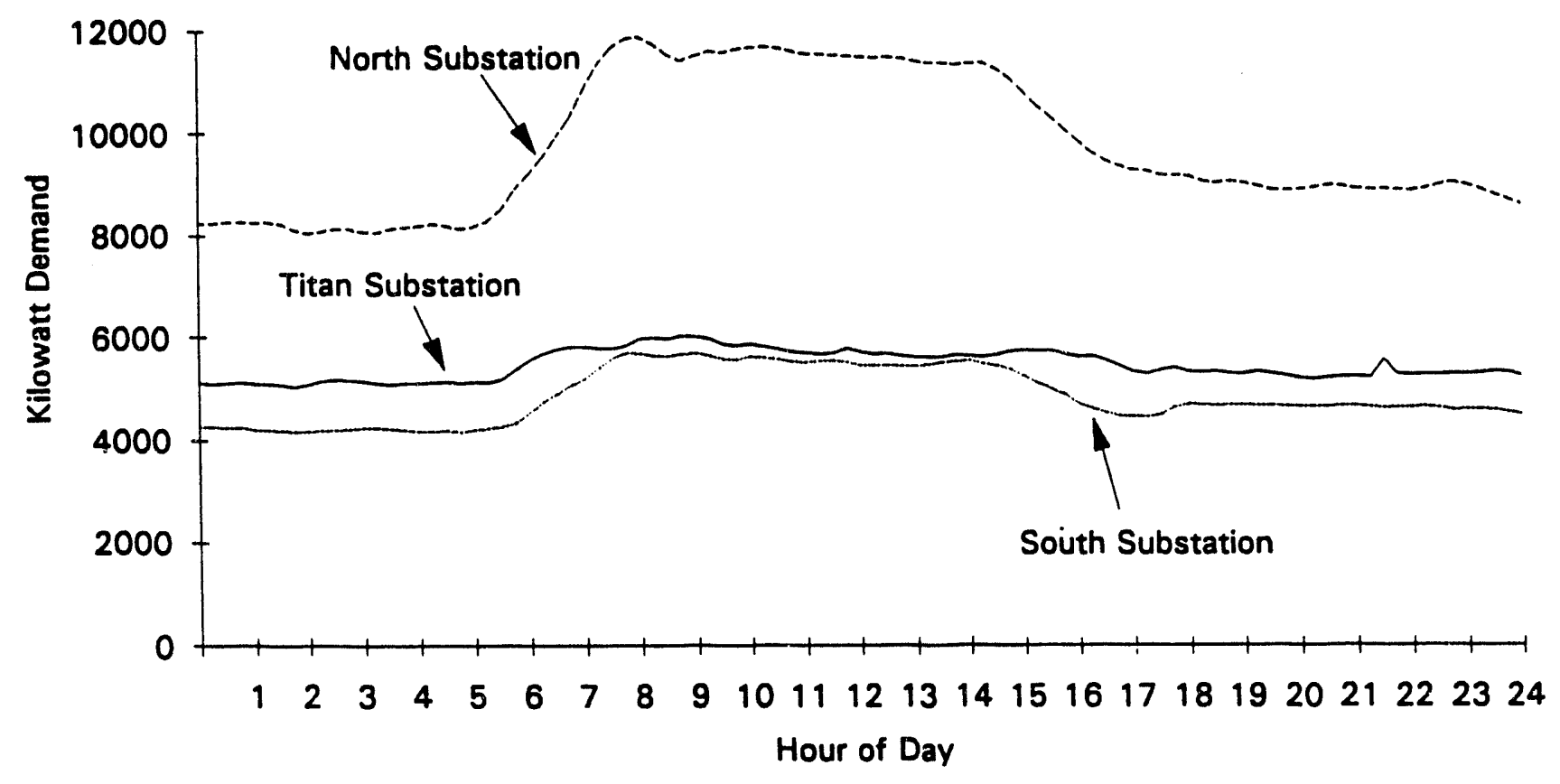

FIGURE 4.9. Load Profile at Cape Canaveral AFS - Winter Weekday (1991)

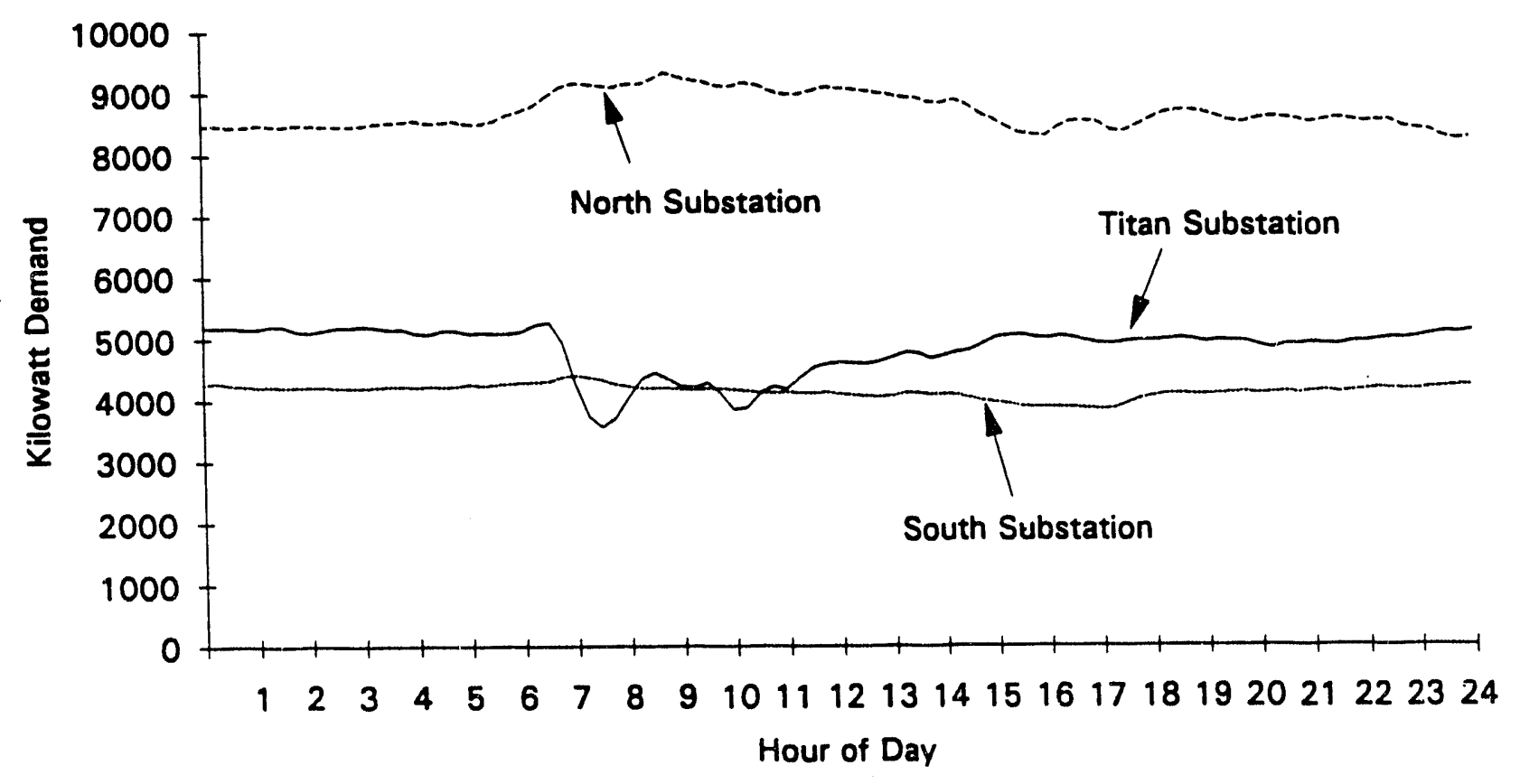

FIGURE 4.10. Load Profile at Cape Canaveral AFS - Winter Weekend (1991) 


\subsection{NATURAL-GAS CONSUMPTION}

\subsection{METERING AND DATA SUMMARY}

Currently, natural gas is not available to any portion of Cape Canaveral AFS. Negotiations are underway between City Gas of Florida, NASA, and the USAF to bring a gas line through KSC to the industrial area of Cape Canaveral AFS and then down to Port Canaveral. If a gas line is installed, natural gas will be available to various portions of the site. 


\subsection{DIESEL FUEL CONSUMPIION}

\subsection{METERING AND DATA SUMMARY}

Fuel-use data are available from the operating contractor, Johnson Controls World Services. Information is available on diesel and fuel oil usage and gasoline use for carts and vehicles. Diesel fuel usage can be divided into three areas: portable generators, larger construction vehicles, and fork lifts and compressors. Fuel $0 i 1$ is used to power boilers. Annual contracts are negotiated with companies to provide and deliver diesel oil and gasoline. Information was not available on fuel usage by specific vehicle or generator.

\subsection{ENERGY-USE BREAKDOWN}

Diesel fuel is used at Cape Canaveral AFS for a variety of activities. Diesel fuel powers portable generators used as back-up power during launch activities and is the primary power source for isolated locations, and fork lifts and air compressors. Consumption data of fuel use in these three areas for fiscal year 1992 are outlined in Table 6.1.

of the three areas of consumption, the use of fuel oil for boilers is the highest, followed by diesel fuel use for fork lifts and compressors, then portable generators. Almost $90 \%$ of the diesel fuel is used to operate fork lifts and air compressors. The monthly consumption patterns for boilers is consistent, while consumption in the other areas has a larger pattern of fluctuation that is dependent on the frequency of launches. 
IABLE 6.1. Fossil Fuel Use for Cape Canaveral AFS - October 1991 through September 1992

Month

Portable Generators (gals)

Boilers

Fork Lifts,

(gals) Compressors (gals)

Total

Oct 1991

11,501

72,814

46,886

77,675

45,677

81,216

39,482

79,898

41,583

67,812

60,127

73,360

57,215

67,204

44,836

76,122

74,337

59,141

64,190

71,685

37,813

$7.1,142$

43,436

73,518

77,060

131,201

146,184

138,188

141,621

142,268

139,402

119,278

141,280

150,820

118,864

140,263

24,745

886,783

617,446

175,323

180,463

$1,684,692$ 


\subsection{REFERENCES}

Bechtel National, Inc. 1992. National Launch System Ground Support Eacilities: Facilities Requirement Plan. San Francisco, California.

Dixon, D. R., P. R. Armstrong, J. R. Brodrick, K. K. Daellenbach, F. V. Di Massa, J. M. Keller, E. E. Richman, G. P. Sullivan, and R. R. Wahl strom. 1992. Fort Drum Integrated Resource Assessment - Volume 2: Basel ine Detail. PNL-8424 Vo1. 2, Pacific Northwest Laboratory, Richland, Washington.

EDAW. Undated. Concept Summary: Base Comprehensive Plan - Eastern Space and Missile Center, Florida. EDAW, Inc., Atlanta, Georgia.

Illuminating Engineering Society of North America (IES). 1981. Illuminating Engineering Society of North America Lighting Handbook. 1981 Application Volume. New York.

McCarthy, K. D. 1992. Load Flow Study for Cape Canaveral Air Force Station Cape Canaveral, Florida. EGG-EE-10478, Idaho National Engineering Laboratory, Idaho Falls, Idaho.

Office of Federal Energy Management Program (FEMP). 1993. Lighting Technology Screening Matrix, Version 2.0 - User's Guide. U.S. Department of Energy, Washington, D.C.

PRAD Group. 1992. Engineering Study of Suitable Refrigerants Replacements at Cape Canaveral Air Force Station and Florida Annexes. Florida. PRAD Group, Atlanta, Georgia.

Wahlstrom, R. R., D. A. King, S. A. Parker, and W. F. Sandusky. 1993. Patrick Air Force Base Integrated Resource Assessment, Volume 2: Basel ine Detail. PNL-8756 Vol. 2, Pacific Northwest Laboratory, Richland, Washington. 


\subsection{BIBLIOGRAPHY}

Johnson Controls World Services (Johnson Controls). 1991. Eastern Test Range, Cape Canaveral Air Force Station Basic Information Guide - 1991 Revision. CDRL No. 044A2, Johnson Controls World Services, Inc., Cape Canaveral Air Force Station, Florida. 


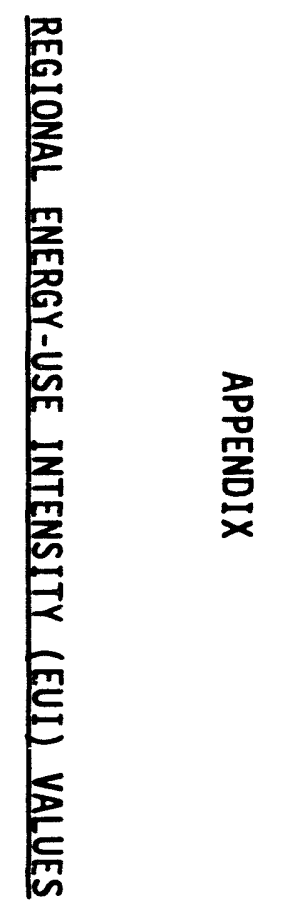


APPENDIX

\section{REGIONAL ENERGY-USE INTENSITY (EUI) VALUES}

Tables A.? through A.19 show the regional EUI information where various sources of information were considered: U.S. Environmental Protection Agency (EPA)/Southeastern Electric Reliability Council (SERC), Gulf Power, Georgia Power, and FPL for the electrical EUIs. All of these sources are shown to indicate that some variation exists among them and that these numbers are not absolute values, but are broad estimates for the various building classifications. However, for this report, the FPL EUI numbers were used to maintain consistency with any work that FPL may do in connection with or related to these efforts. Tables A.1 through A.10 address electrical EUIs. The remaining tables, A.11 through A.19, relate to fuel oil EUIs. EPA/SERC, Gulf Power, and Georgia Power are the sources for the fuel oil EUIs. Average EUI values were determined from the various sources of fuel oil information. There is a considerable variation between the EUIs; thus, average values were used to obtain the EUI numbers used throughout the analysis.

The broad classifications shown for building types (office, restaurant, retail, grocery, warehouse, school, health, lodging, miscellaneous, and church/assembiy) are the way that utilities or other providers of this type of information report their findings. Therefore, the building classifications shown in Table 1.2 were mapped to correspond to the more broad and general categories shown in Tables A.1 to A.19. The criterion used to map the facilities was mainly functionality. The more specific classifications in Table 1.2 were compared to the EUI source information and relationships were noted. 
IABLE A.1. Office Electricity Basel ine Development Notes EUI Development ( $\left.k W h / \mathrm{ft}^{2}-\mathrm{yr}\right)$

Source Heat Cool Vent DHW Cook Light Ref other (a) Total

$\begin{array}{llllllllll}\text { EPA/SERC } & 2.20 & 5.50 & 2.50 & 0.80 & 0.60 & 6.70 & 0.30 & 3.60 & 22.20 \\ \text { GULF POWER } & 0.66 & 3.51 & 0.70 & 0.38 & 0.81 & 2.98 & 0.11 & 1.51 & 10.66 \\ \text { GEORGIA POWER } & 1.64 & 4.30 & 3.00 & 0.70 & 0.23 & 8.12 & 0.24 & 3.30 & 21.53 \\ \text { FPL }^{\text {(b) }} & 0.20 & 6.05 & 1.75 & 0.15 & 0.40 & 7.10^{(c)} & 0.75 & 6.15 & 22.55\end{array}$

EPA/SERC, GULF POWER, GEORGIA POWER, and FPL data for office category.
(a) Defined as miscellaneous EUI.
(b) Average EUI value of large and small office.
(c) Light is combined value of indoor and outdoor.

TABLE A.2. Restaurant Electricity Baseline Development Notes EUI Development ( $\mathrm{kWh} / \mathrm{ft}^{2}-\mathrm{yr}$ )

Source Heat Cool Vent DHW Cook Light Ref Other(a) Total

$\begin{array}{lrrrrrrrrr}\text { EPA/SERC } & 2.30 & 4.30 & 1.90 & 3.90 & 7.20 & 5.20 & 5.50 & 2.10 & 32.40 \\ \text { GULF POWER } & 0.83 & 13.97 & 3.98 & 3.55 & 0.75 & 5.83 & 9.63 & 3.91 & 42.45 \\ \text { GEORGIA POWER } & 0.99 & 22.52 & 3.33 & 2.27 & 10.82 & 10.60 & 17.96 & 4.60 & 73.09 \\ \text { FPL } & 0.30 & 19.70 & 2.20 & 3.80 & 23.10 & 13.00^{\text {(b) }} & 16.90 & 5.60 & 84.60\end{array}$

EPA/SERC, GULF POWER, GEORGIA POWER, and FPL data for restaurant category.

(a) Defined as miscellaneous EUI.

(b) Light is combined value of indoor and outdoor. 
TABLE A.3. Retail Electricity Baseline Development Notes EUI Development ( $\mathrm{kWh} / \mathrm{ft}^{2}-\mathrm{yr}$ )

Source Heat Cool Vent DHW Cook Light Ref other(a) Total

$\begin{array}{llllllllll}\text { EPA/SERC } & 2.30 & 3.10 & 1.40 & 0.60 & 0.90 & 6.10 & 0.70 & 1.40 & 16.50 \\ \text { GULF POWER } & 0.96 & 3.95 & 0.99 & 0.46 & 0.01 & 4.26 & 1.41 & 3.51 & 15.55 \\ \text { GEORGIA POWER } & 1.62 & 4.75 & 1.80 & 0.89 & 0.19 & 6.75 & 0.56 & 2.79 & 19.35 \\ \text { FPL }^{(b)} & 0.15 & 6.90 & 1.25 & 0.25 & 0.40 & 8.01^{(c)} & 1.10 & 2.50 & 20.60\end{array}$

EPA/SERC, GULF POWER, GEORGIA POWER, and FPL data for retail category.

(a) Defined as miscellaneous EUI.

(b) Average EUI value of large and small retail.

(c) Light is combined value of indoor and outdoor.

TABLE A.4. Grocery Electric Basel ine Development Notes EUI Development (kWh/ $\mathrm{ft}^{2}-\mathrm{yr}$ )

Source Heat Cool Vent DHW Cook Light Ref other(a) Total

$\begin{array}{lrrrrrllll}\text { EPA/SERC } & 3.70 & 4.70 & 3.80 & 0.80 & 2.10 & 15.30 & 28.70 & 2.30 & 61.40 \\ \text { GULF POWER } & 0.75 & 10.80 & 2.49 & 0.49 & 0.14 & 10.73 & 16.35 & 2.99 & 44.74 \\ \text { GEORGIA POWER } & 0.32 & 8.23 & 2.23 & 0.69 & 0.77 & 13.23 & 24.00 & 2.71 & 52.18 \\ \text { FPL } & 0.20 & 11.50 & 1.80 & 0.40 & 2.80 & 16.50^{(b)} & 24.10 & 6.00 & 63.30\end{array}$

EPA/SERC, GULF POWER, GEORGIA POWER, and FPL data for grocery category.

(a) Defined as miscellaneous EUI.

(b) Light is combined value of indoor and outdoor. 
IABLE A.5. Warehouse Electricity Basel ine Development Notes EUI Development ( $\mathrm{kWh} / \mathrm{ft}^{2}-\mathrm{yr}$ )

Source Heat Cool Vent DHW Cook Light Ref Other (a) Total

\begin{tabular}{lllllllllll}
\hline EPA/SERC & 1.90 & 1.80 & 1.30 & 0.60 & - & 3.80 & 8.60 & 1.20 & 19.2
\end{tabular}

GULF POWER

$\begin{array}{lllllllllc}\text { GEORGIA POWER } & 0.03 & 1.23 & 0.73 & 0.23 & 0.05 & 1.95 & 0.46 & 0.90 & 5.58 \\ \text { FPL }^{(b)} & 0.20 & 5.40 & 0.20 & 0.00 & 0.20 & 3.30^{\text {(c) }} & 0.50 & 1.80 & 11.60\end{array}$

$0.20 \quad 5.40$

$0.20 \quad 0.00$

11.60

EPA/SERC, GULF POWER, GEORGIA POWER, and FPL data for warehouse category.

(a) Defined as miscellaneous ÉJI.

(b) Non-refrigerated EUI values used.

(c) Light is combined value of indoor and outdoor.

TABLE A.6. School Electricity Basel ine Development Notes EUI Development (kWh/ $\left.\mathrm{ft}^{2}-\mathrm{yr}\right)$

Source Heat Cool Vent DHW Cook Light Ref Other(a) Total

$\begin{array}{llllllllll}\text { EPA/SERC } & 4.20 & 1.30 & 0.60 & 1.10 & 2.10 & 4.20 & 0.40 & 0.60 & 14.5 \\ \text { GULF POWER } & 0.26 & 2.99 & 0.69 & 0.39 & 0.26 & 2.63 & 0.45 & 0.71 & 8.38 \\ \text { GEORGIA POWER } & 0.49 & 1.79 & 0.76 & 0.26 & 0.27 & 2.79 & 0.70 & 1.44 & 8.50 \\ \text { FPL } & 0.20 & 4.30 & 1.40 & 0.70 & 1.50 & 4.5^{(b)} & 0.80 & 1.20 & 14.60\end{array}$

EPA/SERC, GULF POWER, GEORGIA POWER, and FPL data for school category.

(a) Defined as miscellaneous EUI.

(b) Light is combined value of indoor and outdoor. 
TABLE A.7. Health Electricity Basel ine Development Notes EUI Development (kWh/ $\left.\mathrm{ft}^{2}-\mathrm{yr}\right)$

Source Heat Cool Vent DHW Cook Light Ref Other(a) Total

$\begin{array}{llllllllll} & & & & & \\ \text { EPA/SERC } & 2.70 & 6.50 & 2.40 & 2.50 & 0.40 & 5.90 & 0.60 & 2.4 & 23.4 \\ \text { GULF POWER } & 1.20 & 8.79 & 1.97 & 0.50 & 1.06 & 6.28 & 0.95 & 4.40 & 25.15 \\ \text { GEORGIA POWER } & 0.97 & 6.01 & 2.58 & 0.42 & 0.96 & 7.49 & 1.54 & 4.23 & 24.2 \\ \text { FPL (c) }^{2.00} & 9.90 & 7.80 & 3.80 & 1.00 & 9.60 & \text { (b) } & 1.20 & 1.20 & 45.3\end{array}$

EPA/SERC, GULF POWER, GEORGIA POWER, and FPL data for health category.
(a) Defined as miscellaneous EUI.
(b) Light is combined value of indoor and outdoor.
(c) Hospital data from FPL was used for health.

IABLE A.8. Lodging Electricity Basel ine Development Notes EUI Development ( $k W h / \mathrm{ft}^{2}-\mathrm{yr}$ )

\begin{tabular}{|c|c|c|c|c|c|c|c|c|}
\hline Source & Heat & Cool & Vent & DHW & Cook & Light & Ref & other ${ }^{(a)}$ \\
\hline & 00 & 4.90 & 1.40 & 5.80 & 6.20 & 5.30 & 1.10 & 2.40 \\
\hline & 5 & 5.82 & .15 & 0.75 & 0.68 & 5.17 & 0.75 & 4.45 \\
\hline OR & 2.22 & 4.02 & 0.95 & 0.50 & 0.34 & 3.49 & 1.34 & 2.72 \\
\hline 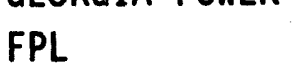 & 0.50 & .40 & .50 & .00 & 1.60 & $5.90^{(b)}$ & 1.50 & 4.10 \\
\hline
\end{tabular}

EPA/SERC, GULF POWER, and FPL data for lodging category. GEORGIA POWER data for hotel/motel category.

(a) Defined as miscellaneous EUI.

(b) Light is combined value of indoor and outdoor. 
IABLE A.9. Miscellaneous Buildings Electricity Baseline Development Notes EUI Development ( $\left.k W h / \mathrm{ft}^{2}-\mathrm{yr}\right)$

Source Heat Cool Vent DHW Cook Light Ref Other(a) Total

$\begin{array}{lrrrrrrrrr}\text { EPA/SERC } & 4.50 & 2.70 & 1.30 & 0.40 & 0.70 & 3.10 & 0.90 & 1.30 & 14.90 \\ \text { GULF POWER } & 2.00 & 12.04 & 6.92 & 0.63 & 0.15 & 12.20 & 1.15 & 11.57 & 46.66 \\ \text { GEORGIA POWER } & 0.23 & 3.30 & 1.18 & 0.28 & 0.25 & 3.62 & 1.07 & 2.39 & 12.32 \\ \text { FPL } & 0.30 & 6.60 & 1.50 & 0.30 & 0.90 & 1.40 & 6.60^{\text {(b) }} & 5.80 & 23.40\end{array}$

EPA/SERC, GULF POWER, GEORGIA POWER, and FPL data for miscellaneous building category.

(a) Defined as miscellaneous EUI.

(b) Light is combined value of indoor and outdoor.

TABLE A.10. Church/Assembly Building Electricity Baseline Development Notes EUI Development ( $\mathrm{kWh} / \mathrm{ft}^{2}-\mathrm{yr}$ )

Source Heat Cool Vent DHW Cook Light Ref other(a) Total

$\begin{array}{llllllllll}\text { GULF POWER } & 0.51 & 2.27 & 0.23 & 0.61 & - & 2.18 & 0.02 & 0.45 & 6.27 \\ \text { FPL (c) }^{\text {(c) }} & 0.30 & 6.60 & 1.50 & 0.30 & 0.90 & 6.6^{(b)} & 1.40 & 5.80 & 23.4\end{array}$

GULF POWER and FPL data for church/assembly building.

(a) Defined as miscellaneous EUI.

(b) Light is combined value of indoor and outdoor.

(c) Miscellaneous building EUI value, which includes church, is used for FPL data. 
TABLE A.11. Office Fossil Fuel Baseline Development Notes EUI Development (kBtu/ $\mathrm{ft}^{2}-\mathrm{yr}$ )

Source Heat DWH Cook Cool Other(a) Total FUEL TYPE: FUEI 011

$\begin{array}{lrccccr}\text { EPA/SERC } & 37.70 & 14.70 & - & - & - & 52.40 \\ \text { GULF POWER } & 3.65 & - & - & - & - & 3.65 \\ \text { GEORGIA POWER } & 1.18 & 0.34 & - & - & - & 1.52\end{array}$

All EUI data for office category.

(a) Defined as miscellaneous EUI.

TABLE A.12. Restaurant Fossil Fuel Baseline Development Notes EUI Development ( $k B t u / \mathrm{ft}^{2}-\mathrm{yr}$ )

Source Heat DWH cook Cool other(a) Iotal

FUEL TYPE: FUE1 011

$\begin{array}{lrrrrrr}\text { EPA/SERC } & 5.80 & 30.60 & - & - & - & 36.40 \\ \text { GULF POWER } & 0.05 & 0.84 & - & - & - & 0.89 \\ \text { GEORGIA POWER } & - & 1.06 & - & - & - & 1.06\end{array}$

A11 EUI data for restaurant category.

(a) Defined as miscellaneous EUI. 
TABLE A.13. Retail Fossil Fuel Baseline Development Notes EUI Development ( $\mathrm{kBtu} / \mathrm{ft}^{2}-\mathrm{yr}$ )

Source Heat DWH Cook Cool other(a) Total

FUEL TYPE: Fue1 011

$\begin{array}{lrccccr}\text { EPA/SERC } & 41.10 & 99.40 & - & - & - & 140.50 \\ \text { GULF POWER } & 0.10 & - & - & - & - & 0.10 \\ \text { GEORGIA POWER } & 0.92 & - & - & - & - & 0.92\end{array}$

A11 EUI data for retail category.

(a) Defined as miscellaneous EUI.

IABLE A.14. Grocery Fossil Fuel Baseline Development Notes EUI Development ( $k B t u / \mathrm{ft}^{2}-\mathrm{yr}$ )

Source Heat DWH Cook Cool other (a) Total

FUEL TYPE: FUe1 011

$\begin{array}{lrrrrrr}\text { EPA/SERC } & 47.80 & 37.60 & - & - & - & 85.40 \\ \text { GULF POWER } & 1.94 & 0.02 & - & - & - & 1.96 \\ \text { GEORGIA POWER } & 0.41 & 0.50 & - & - & - & 0.91\end{array}$

All EUI data for grocery category.

(a) Defined as miscellaneous EUI. 
TABLE A.15. Warehouse Fossil Fuel Başel ine Development Notes EUI Development (kBtu/ $\mathrm{ft}^{2}-\mathrm{yr}$ )

Source Heat DWH Cook Cool Other(a) Iotal

FUEL TYPE: Fue1 011

$\begin{array}{lcccccc}\text { EPA/SERC } & 89.20 & 108.40 & - & - & - & 197.60 \\ \text { GULF POWER } & - & - & - & - & - & - \\ \text { GEORGIA POWER } & 0.17 & - & - & - & - & 0.17\end{array}$

All EUI data for warehouse category.

(a) Defined as miscellaneous EUI.

IABLE A.16. School Fossil Fuel Basel ine Development Notes EUI Development ( $\mathrm{BBtu} / \mathrm{ft}^{2}-\mathrm{yr}$ )

Source Heat DWH Cook Cool Other(a) Total

FUEL TYPE: FUeI 011

$\begin{array}{lrllllr}\text { EPA/SERC } & 78.50 & 32.00 & - & - & - & 110.50 \\ \text { GULF POWER } & 0.01 & - & - & - & - & 0.01 \\ \text { GEORGIA POWER } & 1.18 & 0.12 & - & - & - & 1.30\end{array}$

A11 EUI data for school category.

(a) Defined as miscellaneous EUI. 
IABLE A.17. Health Fossil Fuel Basel ine Development Notes EUI Development ( $\mathrm{kBtu} / \mathrm{ft}^{2}-\mathrm{yr}$ )

Source Heat DWH Cook Cool Other(a) Iotal FUEL TYPE: FUe1 011

$\begin{array}{lrrrrrr}\text { EPA/SERC } & 53.20 & 39.80 & - & - & - & 93.00 \\ \text { GULF POWER } & 0.11 & 0.03 & - & - & - & 0.14 \\ \text { GEORGIA POWER } & 0.83 & 0.69 & - & - & - & 1.52\end{array}$

All EUI data for health category.

(a) Defined as miscellaneous EUI.

TABLE A.18. Lodging Fossil Fuel Basel ine Development Notes EUI Development ( $k B t u / \mathrm{ft}^{2}-\mathrm{yr}$ )

Source Heat DWH Cook Cool Other(a) Total FUEL TYPE: Fuel 011

$\begin{array}{lrrrrrr}\text { EPA/SERC } & 43.90 & 29.00 & - & - & - & 72.90 \\ \text { GULF POWER } & 0.01 & 0.01 & - & - & - & 0.02 \\ \text { GEORGIA POWER } & 0.65 & 1.73 & - & - & - & 2.36\end{array}$

All EUI data for lodging category.

(a) Defined as miscellaneous EUI. 
IABLE A.19. Miscellaneous Buildings Fossil Fulel Basel ine

Development Notes EUI Development (kBtu/ $\mathrm{ft}^{2}-\mathrm{yr}$ )

Source Heat DWH Cook Cool other(a) Total

FUEL TYPE: FUe1 011

EPA/SERC

GULF POWER

56.30

6.80

63.10

GEORGIA POWER

$-$

1.11

0.10

1.12

A11 EUI data for miscellaneous category.

(a) Defined as miscellaneous EUI. 


\section{DISTRIBUTION}

No. of

Coptes

\section{OFFSIIE}

12 DOE/Office of Scientific and Technical Information

K. Dean Devine

Federal Energy Management Program

U.S. Department of Energy EE-44

1000 Independence Avenue SW

Washington, DC 20585

M. Ginsberg

Federal Energy Management Program

U.S. Department of Energy EE-44

1000 Independence Avenue SW Washington, DC 20585

2 L. Harris

Federal Energy Management Program

U.S. Department of Energy EE-44

1000 Independence Avenue SW Washington, DC 20585

F. Beason

HQ AFCESA/ENM

139 Barnes Drive

Tyndall AFB, FL 32403-5319

D. George

Florida Power \& Light

P.0. Box 561190

Rockledge, FL 32955

T. Gildersleeve

HQ AFCESA/ENE

139 Barnes Drive

Tyndall AFB, FL 32403-5319
No. of

Copies

\section{OFFSITE}

V. Juselis

45th CES/CECR

1224 Jupiter Street

Patrick AFB, FL 32935-3343

C. Miller

AF SPACECOMMAND/DEMU

Peterson AFB, CO 89014

B. Starling

U.S. Army Corps of Engineers

Huntsville Division

CEHND-PM-CR

P.0. Box 1600

Huntsville, AL 35807-4301

\section{ONSITE}

DOE Richland Operations office

D. D. Green

23 Pacific Northwest Laboratory

C. A. Anderson

K5-20

R. Bartlett

K8-15

J. W. Currie

K8-54

D. A. King

K8-17

K. L. McMordie

G. B. Parker (2)

K5-08

S. A. Parker

K8-54

D. R. Payson

K5-08

W. F. Sandusky

K7-90

R. R. Wahlstrom

K5-06

Project File (2)

K5-08

Publishing Coordination K1-06

Technical Report Files(5) P8-55 

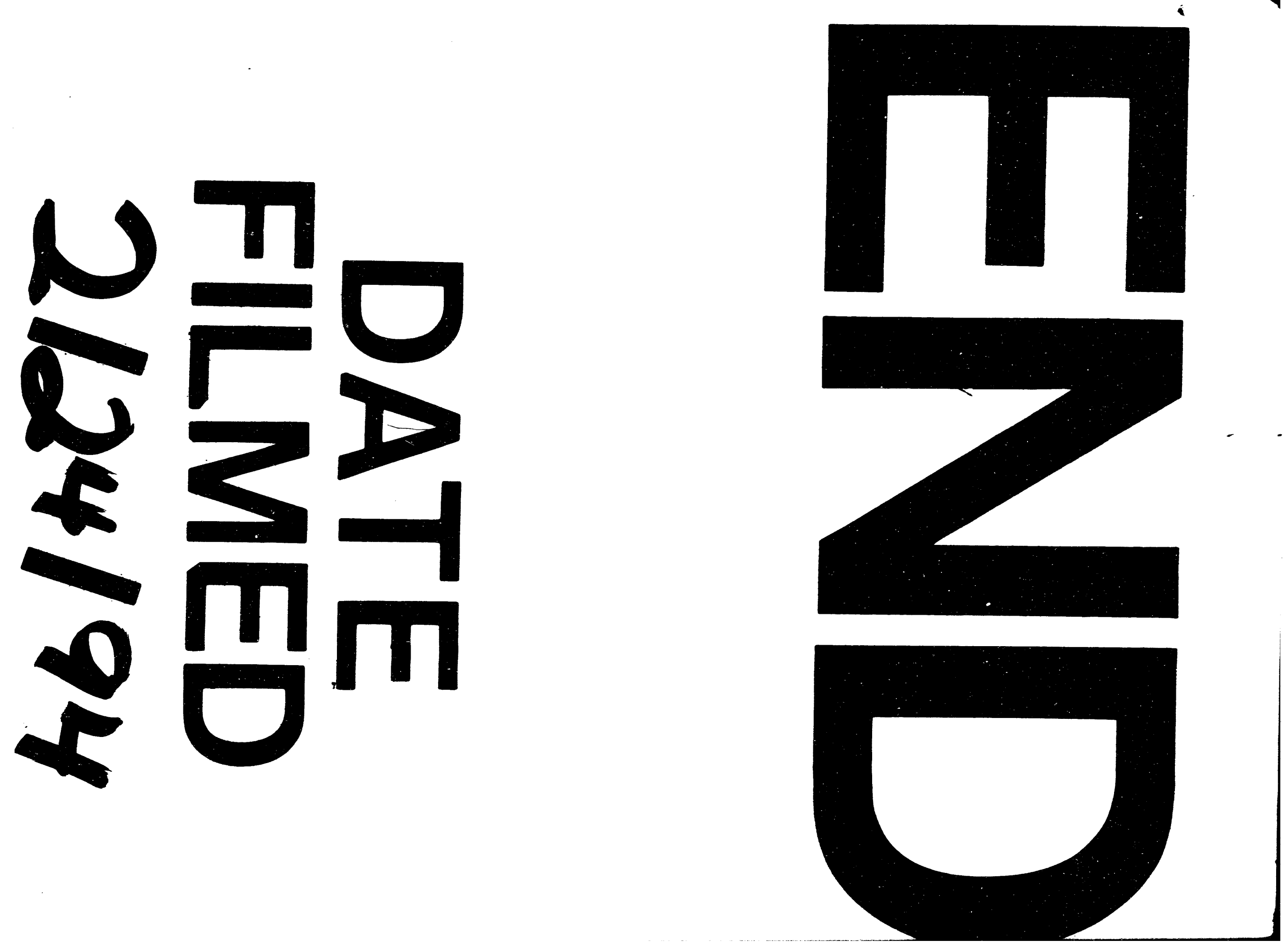
I 